\title{
SPEAR
}

\section{Science Pavilions for Ecological Awareness and Research in Gatineau Park}

by Krista Smith

A thesis submitted to the Faculty of Graduate and Postdoctoral Affairs in partial fulfillment of the requirements for the degree of

Master of Architecture (M. Arch)

Carleton University

Ottawa, Ontario

(C) 2013, Krista Smith 
Library and Archives

Canada

Published Heritage

Branch

395 Wellington Street

Ottawa ON K1A ON4

Canada
Bibliothèque et

Archives Canada

Direction du

Patrimoine de l'édition

395 , rue Wellington

Ottawa ON K1A ON4

Canada
Your file Votre référence

ISBN: 978-0-494-94573-5

Our file Notre référence

ISBN: 978-0-494-94573-5
NOTICE:

The author has granted a nonexclusive license allowing Library and Archives Canada to reproduce, publish, archive, preserve, conserve, communicate to the public by telecommunication or on the Internet, loan, distrbute and sell theses worldwide, for commercial or noncommercial purposes, in microform, paper, electronic and/or any other formats.

The author retains copyright ownership and moral rights in this thesis. Neither the thesis nor substantial extracts from it may be printed or otherwise reproduced without the author's permission.
AVIS:

L'auteur a accordé une licence non exclusive permettant à la Bibliothèque et Archives Canada de reproduire, publier, archiver, sauvegarder, conserver, transmettre au public par télécommunication ou par l'Internet, prêter, distribuer et vendre des thèses partout dans le monde, à des fins commerciales ou autres, sur support microforme, papier, électronique et/ou autres formats.

L'auteur conserve la propriété du droit d'auteur et des droits moraux qui protege cette thèse. $\mathrm{Ni}$ la thèse ni des extraits substantiels de celle-ci ne doivent être imprimés ou autrement reproduits sans son autorisation.
In compliance with the Canadian Privacy Act some supporting forms may have been removed from this thesis.

While these forms may be included in the document page count, their removal does not represent any loss of content from the thesis.
Conformément à la loi canadienne sur la protection de la vie privée, quelques formulaires secondaires ont été enlevés de cette thèse.

Bien que ces formulaires aient inclus dans la pagination, il n'y aura aucun contenu manquant. 

(2)

There is a pleasure in the pathless woods There is a rapture on the lonely shore.

There is society, where non intrudes,

Bv the deep Sea, and music in its roar:

l love not Man the less, but Nature more

- Lord Byron 



\section{Abstract}

Environmental issues are at the forefront of current socio-political debate. Questions arising from the present government's dismantling of ecological field testing stations are being raised by all Canadians who derive from the landscape a sense of pride and, to a certain degree, a "sense" of cultural identity. This thesis therefore proposes an architecture integrated within the landscape to promote the study of environmental sciences of the Canadian landscape while promoting a sensual experience. As a result, the thesis project consists of a series of three pavilions situated in Gatineau Park to raise awareness of the ecosystems and to demonstrate a sustainable architectural relationship to the immediate natural environment. The underlying theory proposes that architecture doesn't need an extensive foundation in order to function successfully. As a didactic design, the proposed architecture aims to educate people about conservation and reestablish a method of construction that has been lost over the years. 



\section{Table of Contents}

Introduction 1

Points of Departure $\quad 8$

Site Context

Description 13

Historical Context 20

General Observations 23

Re-Situating Site 26

Body Intellect 29

A Phenomenology of Discovery 32

Program

Design Intent $\quad 39$

Pavilions as a Design Tool $\quad 42$

Assembly $\quad 46$

Services $\quad 49$

Process

Overview $\quad 54$

Understanding Gatineau Park $\quad 55$

The Journey $\quad 58$ 


\section{Table of Contents}

\begin{tabular}{ll}
\hline Materiality & \\
A Palette for the Senses & 63 \\
Wood & 67 \\
Metal & 69 \\
Stone & 71 \\
Transparency & 73 \\
& \\
Design & 77 \\
Designing for Gatineau Park & 82 \\
Tree & 86 \\
Water & 89 \\
Earth &
\end{tabular}

Pavilion Documentation

Trees Pavilion $\quad 95$

Water Pavilion $\quad 101$

Earth Pavilion 107

$\begin{array}{ll}\text { Post Script } & 114\end{array}$

$\begin{array}{ll}\text { Works Cited } & 116\end{array}$

$\begin{array}{ll}\text { Image Sources } & 119\end{array}$ 



\section{Introduction}

Flexibility and mobility lead to transparency, openness, freedom and spatial dynamism.

- Marcel Breuer ${ }^{1}$

For centuries, the focus of architecture has revolved around permanence and the construction of structures that can seemingly last forever. This is apparent in many Egyptian and Greek temples that are still standing to this day. As a result, the primary focus of today's architecture is to see who can build bigger, better, stronger and faster. In turn, this means that smaller, more modestly built dwellings have rapidly become obsolete in a society that wants more from everything. Yet, there is still a need to develop micro architectures. The smaller scale of the proposed project facilitates the testing of different theories that could potentially be applied to larger, more elaborate projects.

This thesis explores the notion of semi-transient architecture on a smaller scale to propose the potential use of this method in larger projects. The design component developed alongside this thesis proposes three smallscaled conservation pavilions, thematically linked to their site (ie. trees, water, and earth), that serve both educational and research functions within the National Capital Commission's Gatineau Park. By developing a design that

1 Robert Kronenberg, ed. Transportable Environments 3: Theory, Context, Design and Technology. Taylor \& Francis: London, New York, 2006. 53. 
is smaller in scale, the thesis focuses on some of the finer details of architecture that can sometimes become lost, or are altogether ignored in larger works. This micro-design strategy has enabled the project to hone-in on a single concept about site sensitive design in order to push its limits. The notion of semi-transient architecture means that the design is ephemeral and can develop, change or grow over time. This allows for a formal response to changes in the program as well as shifts within the natural environment. However, the design also incorporates transient and permanent qualities to help emphasize these ideas in the final proposal.

It must be noted that this thesis is not trying to forget the city and its importance on human development, but rather on returning to the roots of architecture within a complex natural environment. It enforces the idea of drawing/building from the immediate environment instead of using our ability to blast away and flatten the existing landscape to drop in a piece of architecture with little site context or site understanding. This process critiques the common method of project development where a "tabula rasa" approach ignores the challenges and potential offered by the existing landscape as a point of departure for a design. By responding to the natural surroundings, this environmentally grounded approach has the potential to generate a different type of architecture that is perhaps more expressive of its context with an understanding based on the inherent qualities of the building site.

Rather than romanticizing a lost architectural form, the proposed design process seeks to illustrate the importance of understanding a site context in the development of a building design while aiming to invigorate all of the senses. This approach is in direct contrast to the "desensitization" of architecture found in many of our commercial buildings that has resulted in dwellings that are void of palpable experiences, emotional engagement and memory triggers. Thus, a tactile architecture has been supplanted by 


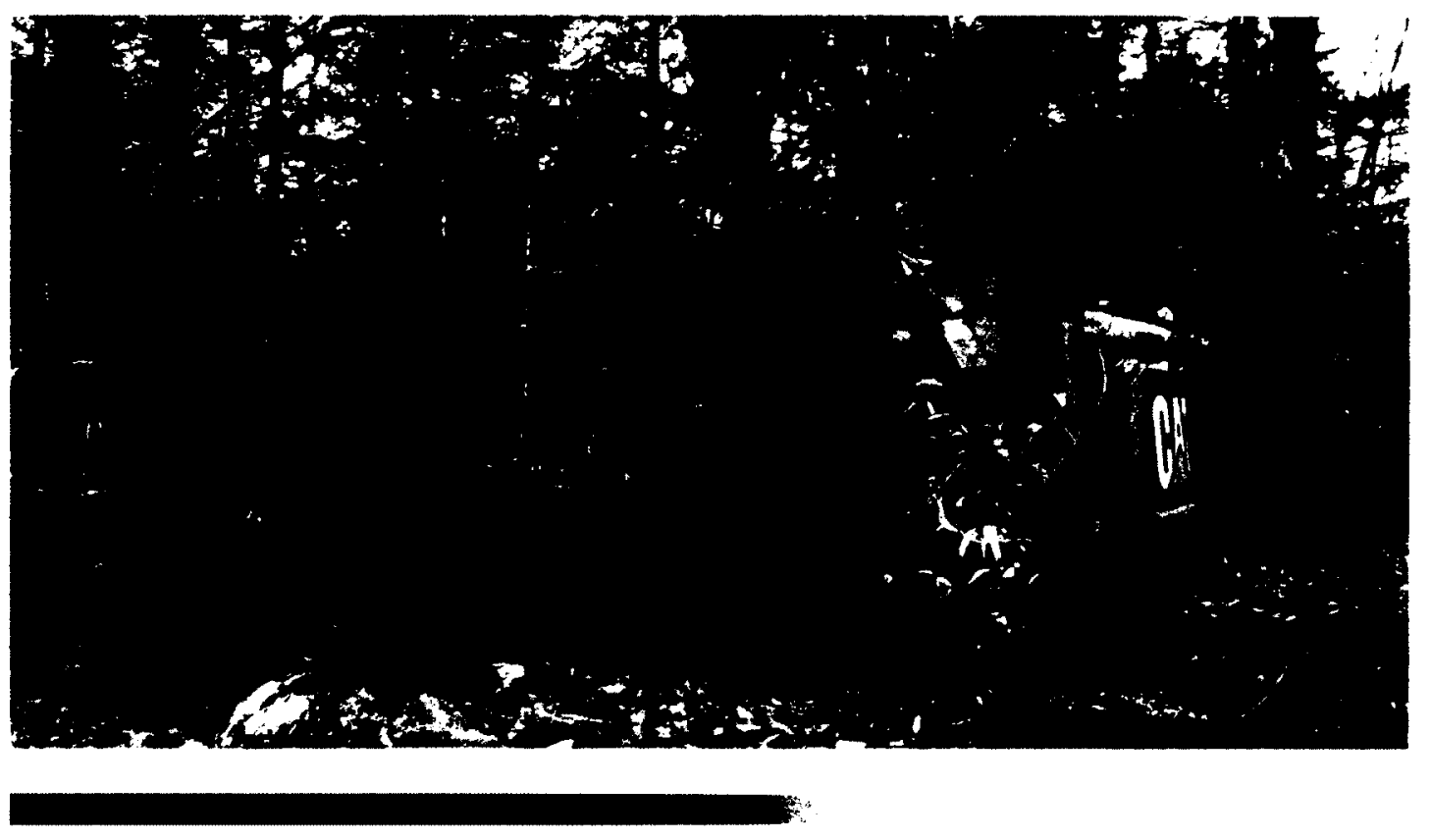

Gatineau Park Intervention 
architecture of economy. As a result, there are many buildings lacking in these key elements that continue to be realized without critical questioning of the resulting effects on our lived environment and daily experiences. Ultimately, our built environment has become engulfed by a "sense-less" architecture that continues to proliferate our "landscape" (both urban and extra-urban). The most extreme example can be seen in the development of "Big Box" stores that seem to appear overnight. In an attempt to react against this sterile architecture, this thesis project proposes a "re-sensitizing" approach to architecture where experience, tactility and playfulness are prioritized.

Many of these issues of desensitized architecture are apparent in Juhani Pallasmaa's texts. In The Thinking Hand, he says:

The art form of architecture mediates and evokes existential feelings and sensations. Architecture of our time, however, has normalized emotions and usually eliminates completely such extreme emotions as sorrow and bliss, melancholy and ecstasy. ${ }^{2}$

This, and other passages, articulates the book's central theme that highlights the importance of craft, sensual experiences, and questioning of our very existence. By eliminating these important factors in design, society is avoiding facing its true "self" and specifically our Canadian identity. ${ }^{3}$ It is thus rendered incapable of facing the factors of life and death, nor its ability to express oneself in a meaningful way.

2 Juhani Pallasmaa. The Thinking Hand: Existential and Embodied Wisdom in Architecture. John Wiley \& Sons Ltd.: Chichester, United Kingdom, 2009. 136.

3 Canadian beer commercials exemplify this notion of cultural identity. Even though they are overly stereotypical concerning the view of the landscape, in this "age of persuasion" they are very telling of our understanding of our connection to the landscape. They illustrate the landscape in a picturesque manner that all Canadians associate with in some fashion and pride themselves on. 
Nevertheless, in trying to react to the desensitization and loss of sensual architecture, this thesis attempts to highlight the importance of designing from a natural environment that stimulates the senses through a design (and design process) for a series of three pavilions thematically linked to their site located within the NCC's Gatineau Park. The design developed for the pavilions acts as a tool to help illustrate the importance of these theories and concepts of meaningful architecture by invigorating the senses in its design. It further emphasizes these ideas by engaging and educating those who visit the pavilions and experience the space. 


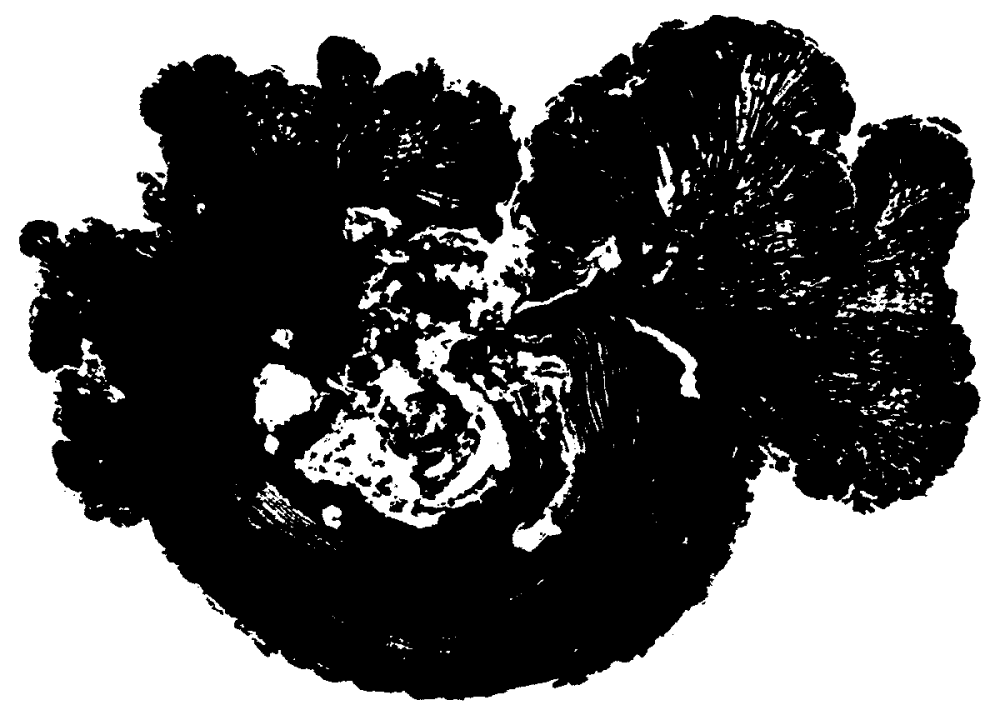

"Cedar Burl" by Bryan Nash Gill 



\section{Points of Departure}

This thesis began in a humble and sympathetic manner inspired by Martha Abbott's observations of ice fishing huts. In her article "Portable Dwelling: The Ice Fishing House and the Fish House Community," she states:

There is a primal human desire to engage creatively with the world that these [ice fishing] settlements ultimately represent. These encampments might serve as a conceptual window into the nature of human desire for an alternate social order arising from their essential connectedness to this place. ${ }^{4}$

A common perception of the "architectural project" within practice, as well as in the academic setting, comes with a supposition that they are essentially urban in their scope and context. Hence, it becomes increasingly apparent that an understanding of architecture within a "natural" environment is being forgotten.

This is especially apparent today where new projects are developed and located on a piece of semi-urban development land - often abandoned farmland. It can also be seen in the relatively untouched context that is the Canadian Landscape in all of its numerous definitions - both ideological and physical. For example, in various cottage areas within Ontario's Canadian Shield, it is apparent that many constructions begin by removing existing trees, blasting away rocks, pouring massive concrete foundations, and

4 Robert Kronenberg, ed. Transportable Environments 3: Theory, Context, Design and Technology. Taylor \& Francis: London, New York, 2006. 65. 
placing a pre-determined pre-designed dwelling upon the resulting "bare" site. Consequently, the charm of a vernacular dwelling emergent from its site that once complemented and embellished the land is now becoming increasingly obsolete. The experience of, and appreciation for, the existing land is gone along with its original features.

In contrast, this thesis found its inspiration from a personal experience during a summer spent helping a bush pilot with one of his remote campsites. The only access to the site is by floatplane or hiking across the hilly landscape. The land is rented from the Ministry of Natural Resources (MNR) with a proviso that the Ministry can at anytime request that the land be vacated, including everything that occupies it, all within twenty-four hours thus returning the land to its original condition.

It is from these personal experiences, as well as other questions concerning architecture in context, that the thesis evolved to address the relationship between a work of architecture and its natural site - an environment of coexistence. Admittedly, there are herein many overlapping themes applicable to both urban design and what I would call "wilderness" design. Including questions of context, tactility, material qualities and experiences, to name a few. Importantly however, a diminutive construction in the wilderness allows for the exploration of construction utilizing basic tools and available local resources, demanding analysis and an appropriate response. Furthermore, designing and constructing architecture for a natural context challenges an individual's understanding of personal abilities and limits while promoting the phenomenological experience of making and dwelling within a context-based setting. 
The spider, dropping down from twig. Unwinds a thread of her devising: A thim, premeditated rig To use in rising.

And all the journey down through space, In cool descent, and loval-hearted, She builds a ladder to the place From which she started.

Thus I, gone forth, as spiders do, In spider's web a truth discerning. Attach one silken strand to you For my returning.

\section{- E.B. White,}

Natural History

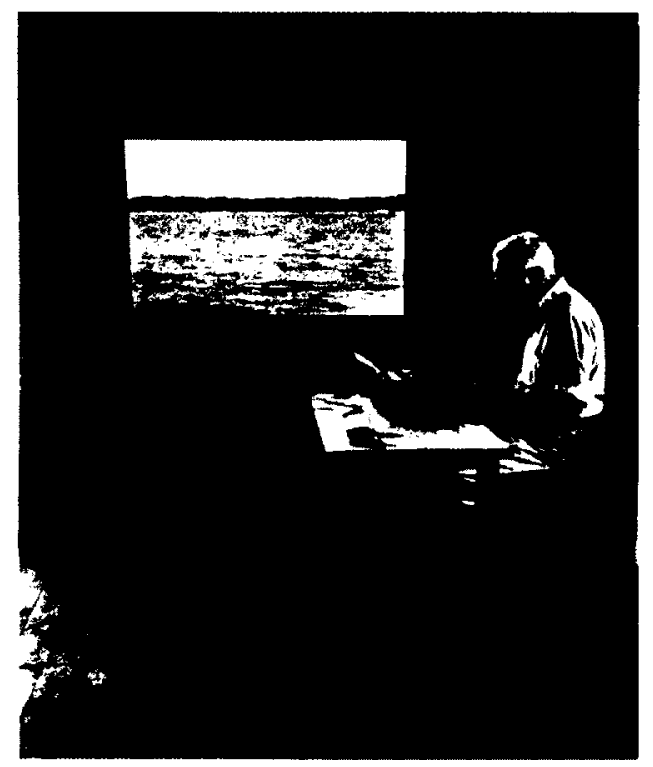





\section{Site Context}

A little time away Back up to the lakes A little time to think Let some trouble sink

Watch the sumrise Light a little fire Watch the smoky lines Cut between the pines

Cut between the pines In the darkness in our minds Shed a little light

So far away tonight

- Elliott Brood,

"Northern Air"

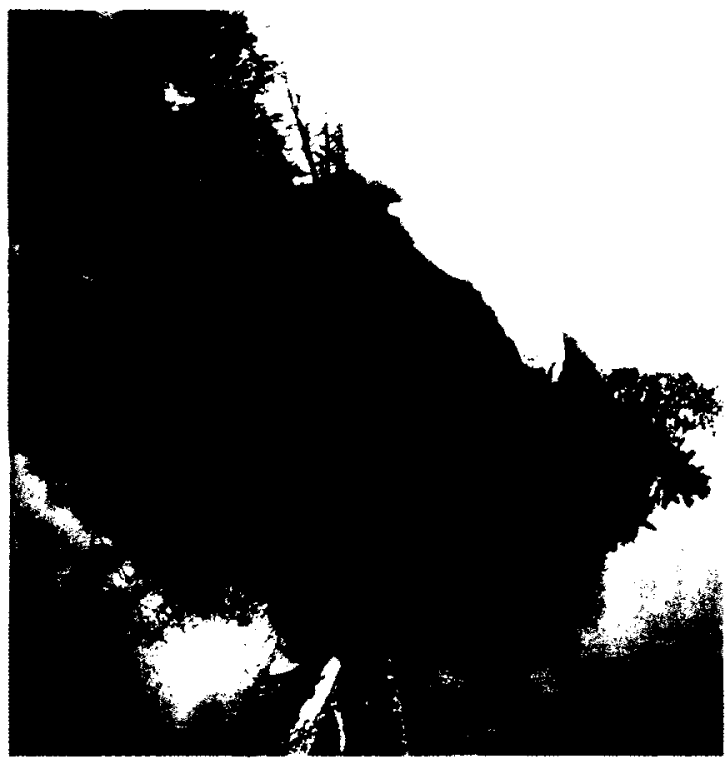




\section{Description}

I went to the woods because I wished to live deliberately, to front only the essential facts of life, and see if I could not learn what it had to teach, and not, when I came to die, discover that I had not lived.

- Henry David Thoreau 5

The Canadian landscape contains beautiful, diverse, regional transitions that offer rich environments to explore. A portion of this vast landscape, the Canadian Shield more specifically, serves as the backdrop for the thesis' design component. This geographic region was selected because of the diversity and richness it embodies. It's made from a variety of soils, rocks, minerals, vegetation and pockets of water. This region also covers the majority of Canada.

A specific site within the Canadian Shield was selected in the NCC's Gatineau Park, near Chelsea, Quebec. The park is located within the southern region of the province. Just north of Ottawa, Canada's Capital, and the Quebec-Ontario border. Gatineau Park is considered the Canadian Capital's Conservation Park and covers a total of $361 \mathrm{~km}^{2}$ of land. ${ }^{6}$ This region was selected because it is emblematic and embodies the Canadian Shield landscape. This includes the unlevel terrain, pockets of water, and dense

$5 \quad$ Henry David Thoreau. The Variorum Walden. New York: Washington Square Press, 1967. 67.

6 National Capital Commission "About Gatineau Park" 15 Dec. 2012.

<http://www.canadascapital.gc.ca/places-to-visit/gatineau-park/about-gatineau-park>. 

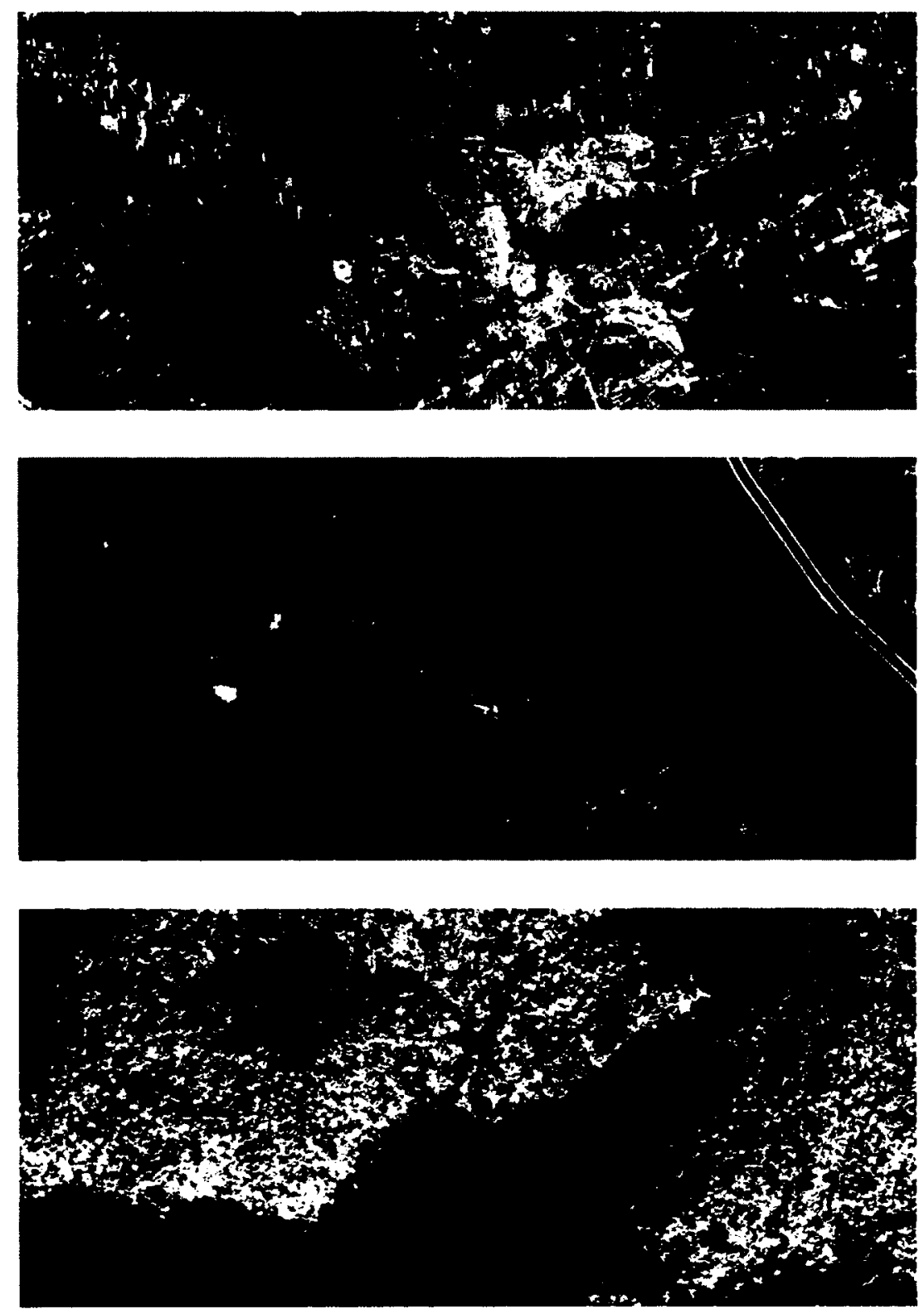

Site Aerials 


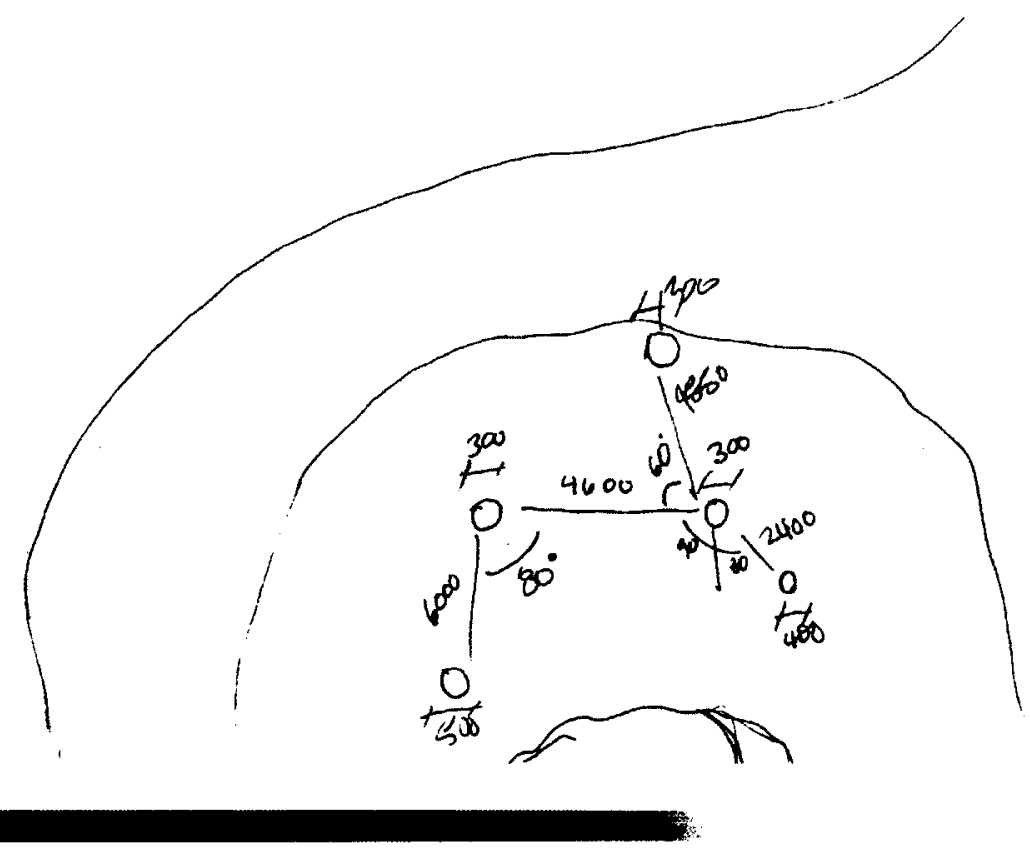

Hand Drawn Tree Site Map 
forest coverage. All of these factors are imperative in influencing the design of the project.

Within Gatineau Park an exact spot was selected to develop the design. It is located off Trail 36 next to Meech Lake. The site is discovered by traveling $1 \mathrm{~km}$ along Trail 36 and then by traveling an additional few hundred meters south west of this location towards Meech Lake. This area contains a hill with a clearing surrounded by five large trees, the shores of Meech Lake, and a swamp area.

Three of the trees on the hill are approximately $300 \mathrm{~mm}$ in diameter while another is $500 \mathrm{~mm}$ and one more is $400 \mathrm{~mm}$. The three $300 \mathrm{~mm}$ trees are triangulated and spaced roughly $4600 \mathrm{~mm}$ and $4550 \mathrm{~mm}$ apart from each other. The $400 \mathrm{~mm}$ tree is approximately $2400 \mathrm{~mm}$ from one of the $300 \mathrm{~mm}$ trees. Lastly, the $500 \mathrm{~mm}$ tree is spaced roughly $6000 \mathrm{~mm}$ from a different $300 \mathrm{~mm}$ tree. The spacing between the trees is sufficient to locate one of the designs. It is also used to generate the ground floor plan.

The need for water has always been an important factor in human, and animal, survival. As a result, the site is located along the shores of Meech Lake. The lake is located along the southwest bank of the site. Along the shoreline, the water is about $150 \mathrm{~mm}$ deep and gradually deepens as it progresses to the middle of the lake. The surface of the bottom of the lake is comprised of sand and rocks.

The ground in this area is a blend of different minerals and soil types. The stony soils of the Gatineau region contain a mixture of clay, silt, sand, pebbles and boulders that were all deposited from the glacier that once 
occupied the land. ${ }^{7}$ It also contains a variety of vegetations that interact with the soils. This combination of soil types creates an unlevel terrain that poses minor challenges to the designs foundations.

The ideal location to place a dwelling is on top of the hill. The elevated position alleviates concerns about flooding in the springtime when the snow begins to melt and the water levels rise. Furthermore, the trees in this location help to shelter the design from damaging winds and shade it from harsh sunlight intense during the summer.

As a whole, the site embodies all of the characteristics that help support the thesis through its programming and design strategy. The natural environment of the site helps push concepts and ideas explored within the thesis by designing a series of pavilions based on the existing site conditions as well as the mandate of scientific research. Additionally, it enforces the importance of designing architecture for the senses on one hand, and scientific observations on the other through a thorough understanding of site, context and phenomenological experiences. Hence, it balances both a subjective and objective perception of space to influence a design.

7 Natural Resources Canada. "Changing Landscape". (2008) 23 Mar. 2013. <http://www.nrcan.gc.ca/earth-sciences/products-services/mappingproduct/geoscape/ottawa/6275>. 


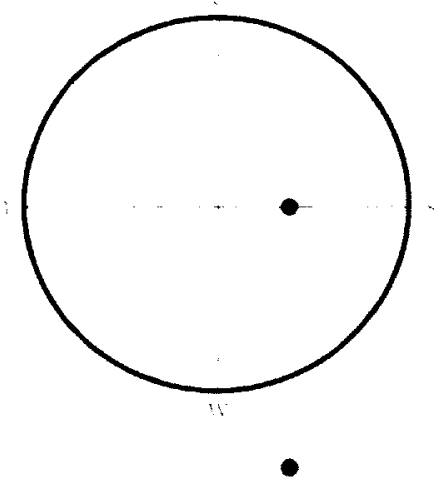

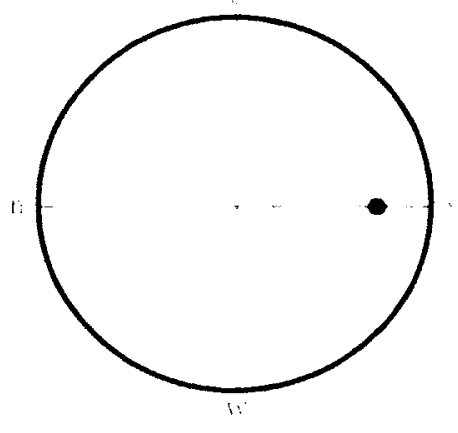

-

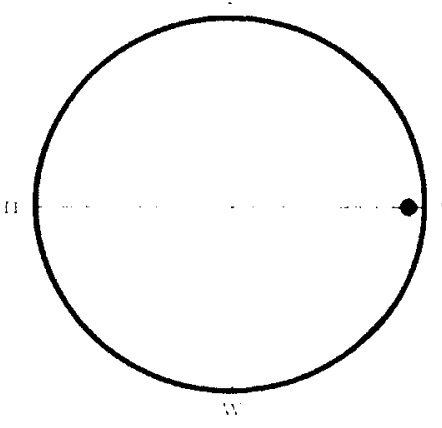

-

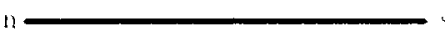

Full Smong Equinus:

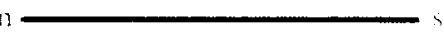

Nintel Sulario

Gatineau Park Sun Paths: Summer Solstice, Fall/Spring Equinox, and Winter Solstice 


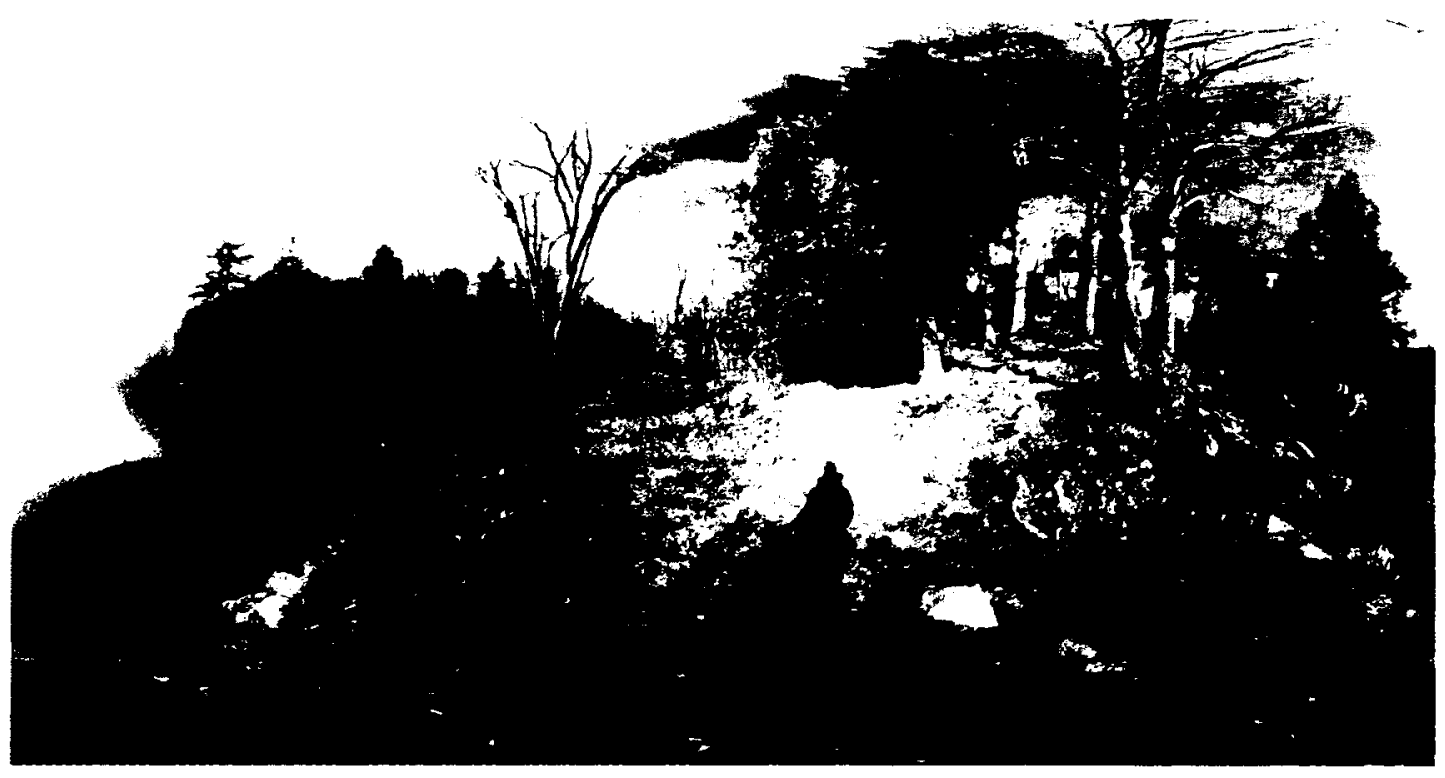

Site Panorama 1 


\section{Historical Context}

In this age of technology, where you can manipulate anything, how do we retain that human element?

- David Grohl ${ }^{8}$

The history of Gatineau Park is rich with many physical, and nonphysical, remnants still visible today. The park was born on July 1, 1938 when the Canadian government, led by William Lyon MacKenzie King, acquired the land and surveys in connection with the national parkway in the Gatineau Valley and started assembling them together. ${ }^{9}$ Had it not been for MacKenzie King's personal connection to the Gatineau Hills (he would spend his free time in the region) the park may never have been realized.

Prior to the park's conception, the Aboriginal population inhabited the area before the settlers and early industrialists took root. There is archaeological evidence located throughout the park illustrating that the Algonquin people called this region their home approximately 4000 years ago. ${ }^{10}$ It wasn't until the early 1600 s that French explorers arrived followed by various trappers and fur traders. ${ }^{11}$ It was in the 1800 s that many changes

8 Sound City. Dir. David Grohl. Perf. Trent Reznor, Tom Petty and Mick Fleetwood. Therapy Content, 2013. Film.

9 Canadian Parks and Wilderness Society. Gatineau Park: A Threatened Treasure. 2008. 1112.

10 Ibid, 11.

11 Ibid, 11. 
to the area's ecosystems took place. Activities in the region included extensive logging, the construction of roads, clearing land for farming purposes, and digging mines. ${ }^{12}$ It wasn't until the 1900 s that interest in transforming the area into a park transpired. ${ }^{13}$

Today, the National Capital Commission controls the park. ${ }^{14}$ According to the NCC the region is considered the Capital's Conservation Park, it covers $361 \mathrm{~km}^{2}$ of land, and receives 2.7 million visits per year. ${ }^{15}$ Their focus is to maintain the natural and cultural heritage of the park while offering outdoor recreation options that are respectful of the environment. ${ }^{16}$

The park has transformed over the years with the hope of maintaining the natural setting and culture of Canada. It is a treasured piece of land that will continue to be used by Canadians and visitors for generations to come. This means that it is imperative to understand the park's history and how it can be developed to last.

\footnotetext{
12. Canadian Parks and Wilderness Society. Gatineau Park: A Threatened Treasure. 2008. 11.

13 Ibid, 12.

14 Ibid, 13.

15 National Capital Commission "Heritage and Culture in Gatineau Park" 20 Dec. 2012. <http://www.canadascapital.gc.ca/places-to-visit/gatineau-park/conservationgatineau-park>.

16 Ibid.
} 


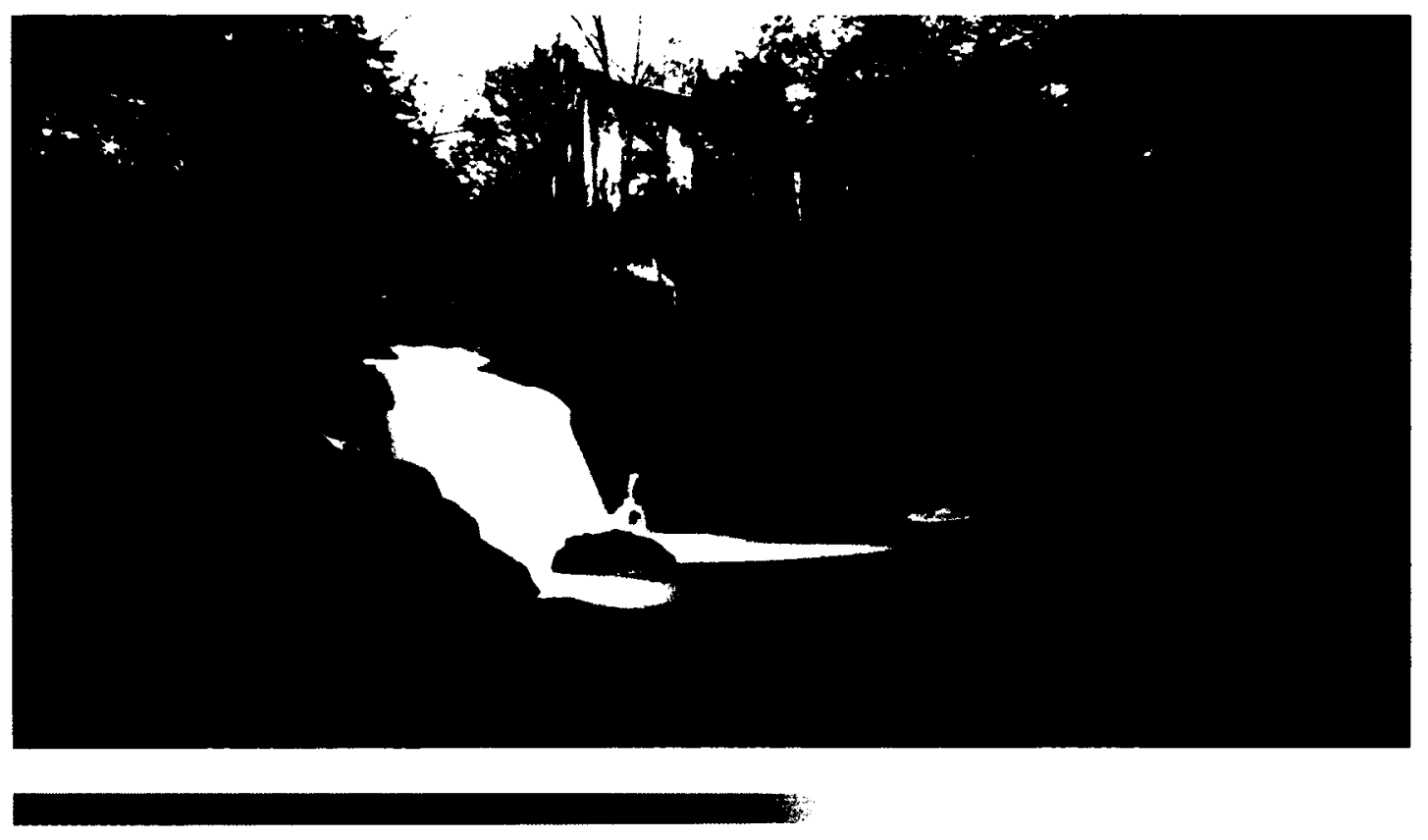

Carbide Wilson Ruins 


\section{General Observations}

And what a dynamic, handsome object is a path! How precise that familiar hill path remains for our muscular consciousness!

- Gaston Bachelard ${ }^{17}$

Walking along trail 36, there are several groups of people hiking along its dirt path. They vary in age from an elderly man walking the trail with his cane to a group of young and vibrant children running, playing and laughing. From first glance there is no visible common ground between any of them. It could be argued that it's more of a psychological factor that is the common link between them - their need to connect and their appreciation for nature.

It is evident within Gatineau Park that there are dwellings constructed in different locations that are much larger than the small public huts constructed by the NCC. As a result, by placing smaller pavilions in the selected area, and by situating them across the lake from the larger architectural constructions that already exist, it juxtaposes the concept of pre-meditated architecture against architecture designed from a site. Instead of clearing the site of vegetation and placing a pre-determined piece of architecture in its place, the pavilions are designed based on the existing site conditions utilizing a "kit-of-parts".

17 Gaston Bachelard. The Poetics of Space. Beacon Press: Boston, 1969. 11. 
In his book Micro Architecture, Richard Horden states:

The beauty of nature is also the key to our involvement with extreme environments. It is the respect for nature and the very needs of the people living and working there that are the generators of micro architecture, not technology or the aim to achieve something high-tech. ${ }^{18}$

This statement has much validity in today's world of fast-paced technological developments. Society has become more invested in advancing the technological savvy world than developing an understanding of minimum essentials for survival. By taking the road less travelled it generates a better self-awareness and self-understanding. Thus by developing smaller works of architecture, the connection between nature and self can be understood.

Again, even with the advanced technological world that defines contemporary society, there is an increasing need for a relationship to nature. The ability to understand how to use ones hands and respond to an environment is what links people to their history and cultures. Overall, the influence nature has on individuals, even if they seem slightly blinded by the technological realms that enrobe them today, are still imperative.

Richard Horden. Micro Architecture. Thames \& Hudson Ltd.: London, 2008. 100. 


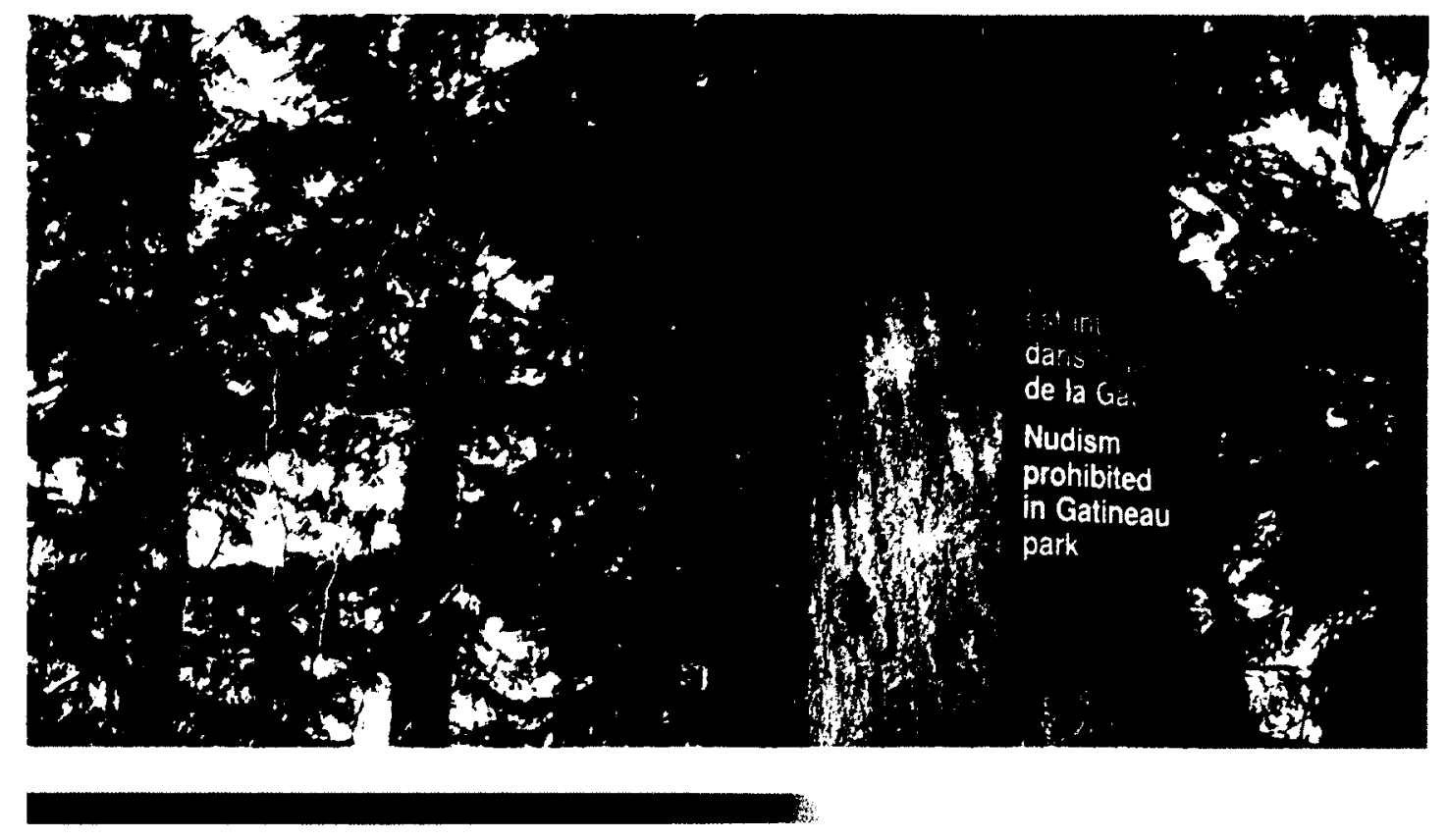

Gatineau Park Nudism Prohibited 


\section{Re-Situating Site}

Here the spatial is an arena of possibility.

- Doreen Massey 19

The pavilions are situated in Gatineau Park, a site that is emblematic of the Canadian Shield that covers the majority of central Canada. The site acts as a testing ground for the pavilions and their "kit-of-parts" assembly. The themes of the pavilions have been derived from the site and the journey along Trail 36. This influenced the designs and, based on their immediate context, created variations on the "kit-of-parts".

Since the pavilions utilize a "kit-of-parts" system, they can be easily dismantled, displaced and reconfigured in other regions within the park Thus, if there are more focused experiments that require the shelters to be repositioned and reconfigured, they can adapt with ease. This also reinforces the notions of temporality and adaptability that are inherent to the pavilions' design. Thus the relocation of the pavilions can generate a new understanding of their sites through their integration with them.

For example, along Trail 36 there are several rock faces that line the pathway. Any one of these can be used to "house" a pavilion. In one particular area there is a small ditch beside the path before a large rock face abuts it.

19 Doreen Massey. For Space. SAGE: Thousand Oaks, Calif., 2005. 109. 
Using the "kit-of-parts," the Earth Pavilion can be adapted to be located within or adjacent to the ditch, pressed up against the rock face. In this scenario, the rock face creates an interior wall within the pavilion to promote a closer connection to scientific observation. The post and beam structure remains the same but the sliding panels vary according to their new context. Instead of being filled with vegetation between the glass pane and metal mesh, the envelope would be composed from different rock samples. This encourages a heightened experience of observation and interpretation through a closer connection to the site and its features - a dual understanding of objective and subjective contexts. 

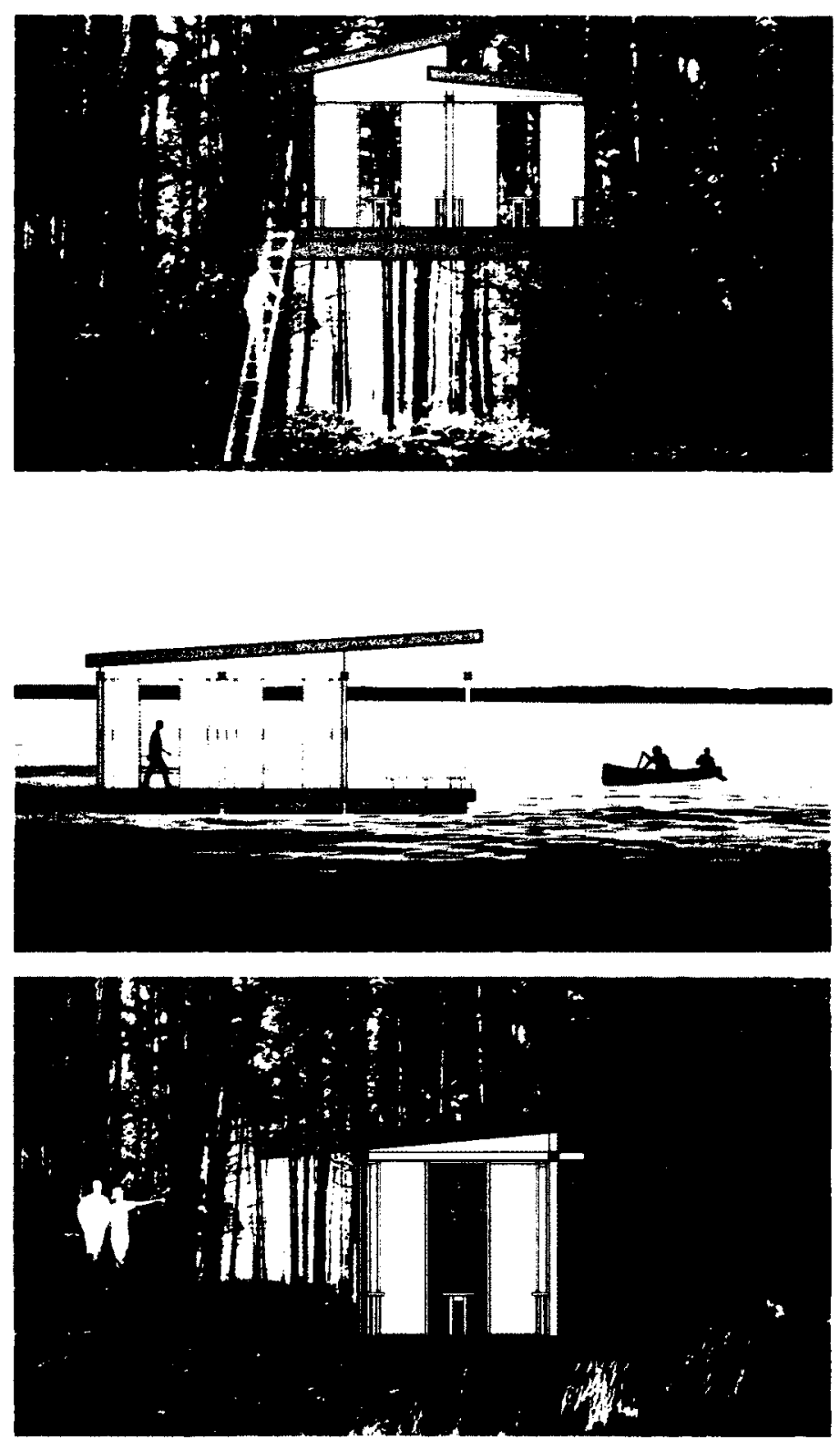

Pavilion vs. Trees

Pavilion vs. Water

Pavilion vs. Rock Face 


\section{Body Intellect}

Nothing determines me from outside, not because nothing acts upon me, but, on the contrary, because I am from the start outside myself and open to the world. - Maurice Merleau-Ponty2o

Architecture is one of the few fields of study that attempts to understand space and how it is occupied in multiple human dimensions. Designers spend endless hours trying to capture or evoke a feeling within a space. Yet there are two sides to understanding a spatial complex. This includes the bodily experience of a space and the intellectual understanding of a space.

The first way to understand a space is through the bodily experience. This is what one feels when they interact with a space on a physical, or mentally subconscious, level. It is the "hands-on" interaction with the environment through the body. Marco Frascari elaborates on this concept in his article "A New Corporeality of Architecture". He says:

This dual-body image results from an understanding of corporeality as the central focus of the architectural presence. A presence which is not only a being, but it is also a becoming. Body, perception and memory are the elements composing a growing spiral on which a true relationship theory-practice 
should be built. This will give back to architecture its original nature of being a specific discipline with its own proper theoretical knowledge, which can be then transferred in the instrumental knowledge necessary to its practicing. ${ }^{21}$

Thus by understanding the space through the body, it is easier to make connections between oneself and the space we occupy. As an architect, this is very important when developing new works of habitable architecture.

The alternative way of understanding a space, as Frascari mentions in his article, is on an intellectual level - both interpretive (metaphorical) and reasoned (factual). This occurs when one examines a space through a scientific approach. It results in an individual's conclusions from a collection of data. This includes everything from the makeup of the earth to the topographic planes generated from a satellite. It is a way of understanding the context of a site by abstracting the information derived from various scientific systems and methods. This means that there is no physical connection to the region, just an understanding of the facts in a disconnected mental state.

Separately, these various approaches to understanding space generate different results. However, when they are combined together they generate a sense of unity within a space. By being able to understand a space on both a physical and mental level, it affirms an individual's concepts concerning the environment. It enables a space to be understood through the experience and the interpretation of ideas. They are able to appreciate the space they create by relying on more than a single method of analysis.

21 Marco Frascari. "A New Corporeality of Architecture." Journal of Architectural Education, Vol. 40, No. 2, Jubilee Issue (Winter, 1987), 22. 


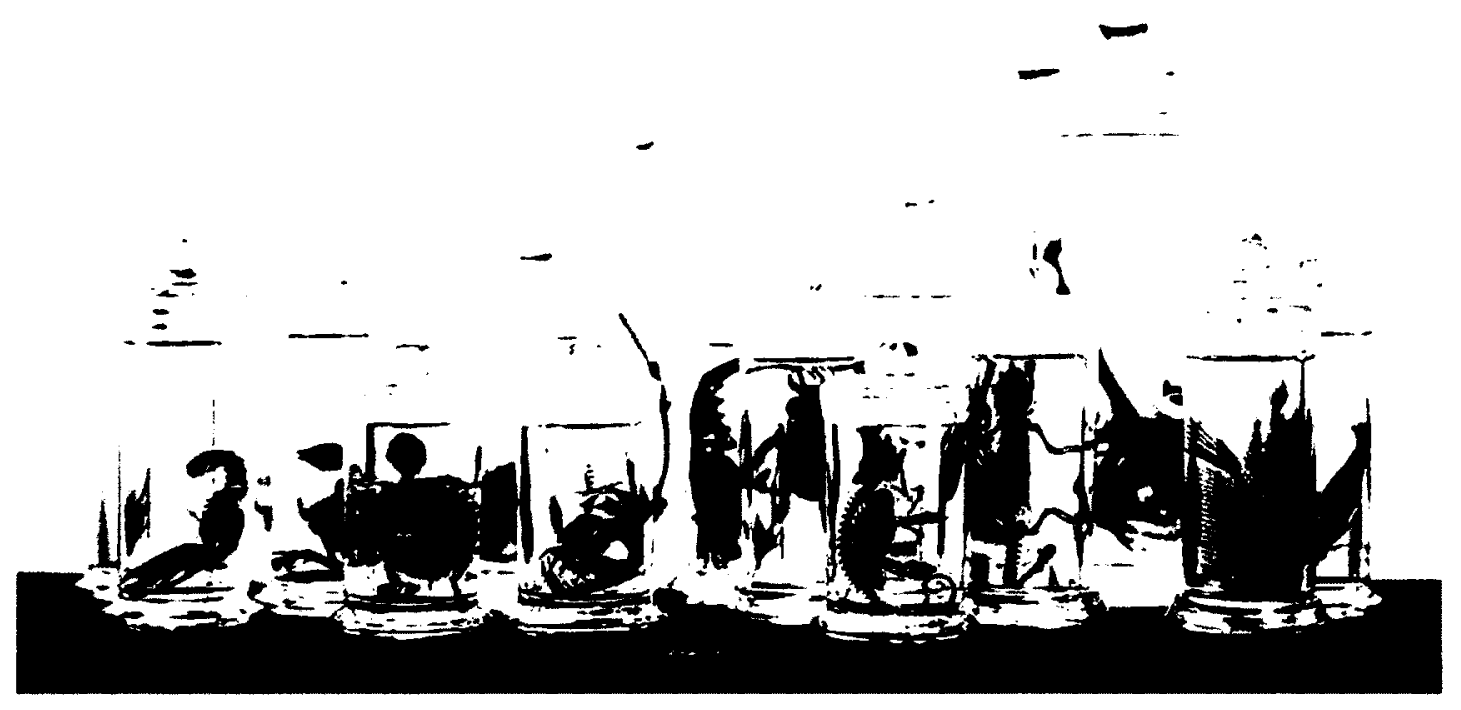

"New World Transparent Specimen" by Iori Tomita 


\section{A Phenomenology of Discovery}

Modern commercial existence muddles the question of what is essential.

- Steven Holl22

This thesis project aims to bridge two modes of experience in our natural world. The first is biological sciences. It can provide objective documentation and analysis of natural phenomena. It also provides a study into the changing states of our natural environment. The second model is phenomenology. It allows us to study the subjective experience of dwelling within this environment in order to appreciate the intricate relationships of the phenomena of our sensual perceptions as well as our understandings of the world around us.

David Woodruff Smith's article, "Phenomenology" in The Stanford Encyclopedia of Philosophy, states that the term is often restricted to the characterization of sensory qualities (seeing, hearing, etc.). ${ }^{23}$ Yet, our experiences are much richer in content than mere sensations. ${ }^{24} \mathrm{He}$ argues that phenomenology studies the structure of various types of experience including perception, thought, memory, imagination, emotion, desire, volition

\footnotetext{
22 Steven Holl, Juhani Pallasmaa and Alberto Pérez-Gómez. Questions of Perspective: Phenomenology of Architecture. a+u Publishing Co., Ltd.: San Fransico, CA., 2006. 40.

23 David Woodruff Smith. "Phenomenology." The Stanford Encyclopedia of Philosophy. (Fall 2011 Edition) 4 May. 3013. <http://plato.stanford.edu/archives/fall2011/entries/phenomenology/>. Ibid.
} 
to bodily awareness, embodied action, social and linguistic activity as well as the senses. ${ }^{25}$ It is more about the directedness of experiences towards things in the world through what Husserl called "intentionality." 26 Thus, phenomenology studies the range of our experiences both passive and active to generate a better understanding of self and place.

In this context, architecture can be seen as a "frame" within which both modes of perception and experience (objective and subjective) can coexist. Further, the architectural condition aims to assist in the activities of scientific analysis (the gathering of scientific data) while highlighting or enhancing the sensual and perceptual experience of the inhabitants.

The pavilions are easily measurable since they are physical constructs. This includes the distance between structural beams and posts, the amount of lumber required, the dimensions of the lumber, and the number of sliding panels needed. They are all-quantifiable factors. Even the distance it takes to travel to the pavilions can be associated with a number. Yet, there is also another layer to the measurements involved in the pavilions - the scientific ones gathered from the researchers. This includes everything from the amount of tadpoles in a water sample to the number of blades of grass in a given squared-off area. These scientific measurements generate a different sense of understanding with respect to the site and the natural context.

The pavilions function as a programmed space for researchers performing basic scientific investigations about the park's environment. As a mediating condition, they also enable a closer interaction and

\footnotetext{
25 David Woodruff Smith. "Phenomenology." The Stanford Encyclopedia of Philosophy. (Fall 2011 Edition) 4 May. 3013. $<$ http://plato.stanford.edu/archives/fall2011/entries/phenomenology/>.

Ibid.
} 


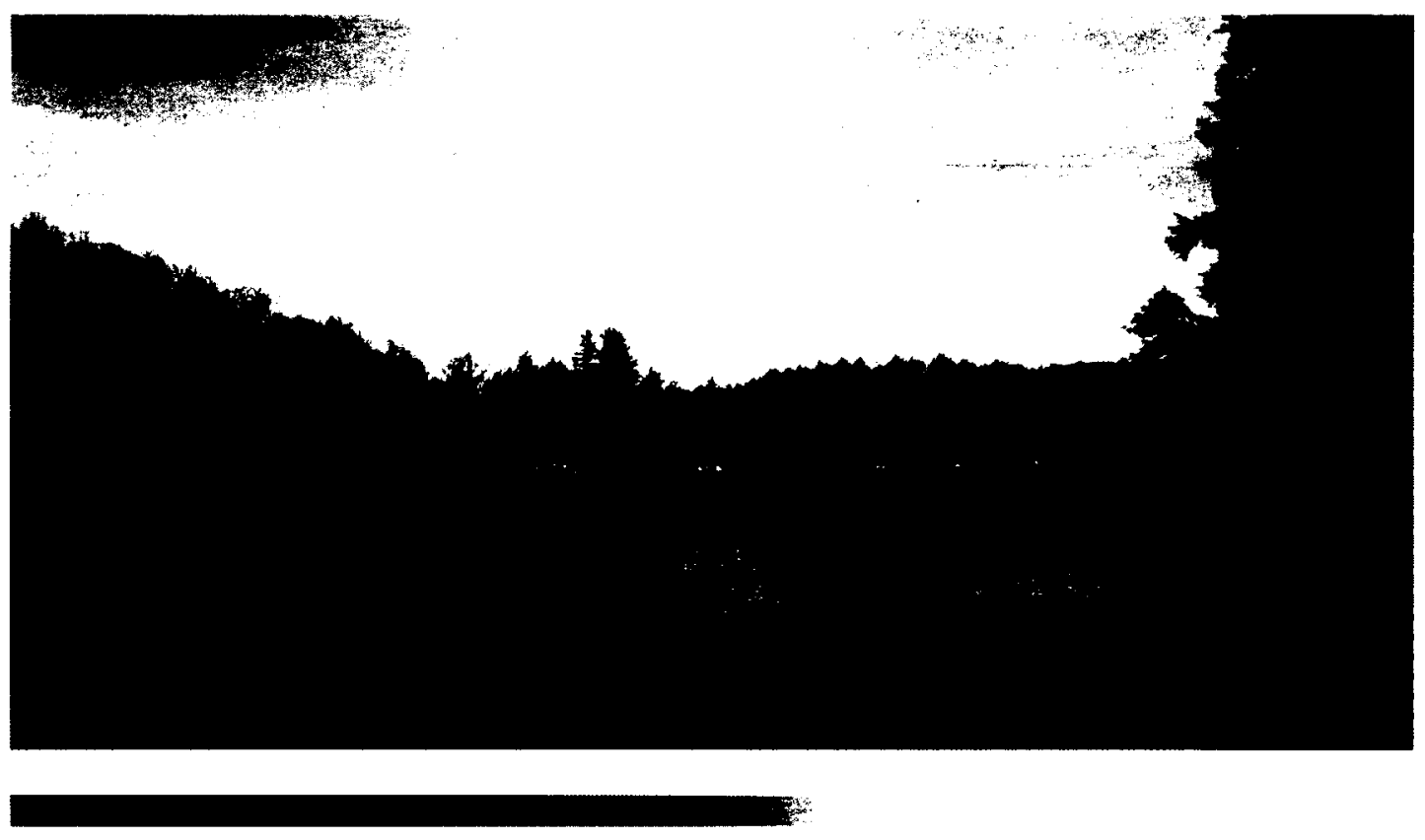

Meech Lake Crossing 
communication between scientists and visitors relating to research and scientific findings in Gatineau Park. While there is a defined objective for the pavilions' functions (collection and exhibition space, lecture area, sleeping quarters, research space, etc.), the architecture also aims to complement the sensual experience of the building and its natural context, thus offering a phenomenological framework for this experience.

There is a cultural aspect to the pavilions' designs. Traditional components of the post and beam and wood frame construction reference the long Canadian tradition of craft and fabrication from abundant natural resources. Formally, this construction method also harkens to recognizable typologies ranging from pitched roofs to rhythmic spacing of stick-frame components reminiscent of early cottages, cabins and camps. The use of these typologies reflects on the traditional methods of this construction while utilizing contemporary technologies to aid in the connections and flexible assembly techniques. The wood acts as the traditional material reflecting upon Canada's long standing history with wood frame construction, while the metal fasteners act as the contemporary intervention to assist with quick assembly and disassembly. This results in a structure that is not only reflective of cultural traditions but also of temporality.

All of the materials selected to construct these pavilions were chosen from an interpretation of localized site conditions and are reflected in the final designs. These natural traits are framed by the architecture while the architecture is informed by the condition itself. The component part of interpreting these site conditions includes a historical perspective of its previous states and the past events contributing to its current condition. For example, the wood structure within the pavilions bridges the connection of the current second-generation forest while alluding to the park's deforestation history in the early 1800 s. To reinforce a more immediate narrative potential of the architecture, a material strategy was employed in 
the sliding panels. By slightly varying the materials used to infill them, these apertures reinforce the connection between the visitor and the site by alluding to the pavilion's main subject of research (trees, water and earth). In doing so, the designs express the architect's intentions to the viewers as they approach the pavilions.

Although these pavilions appear as simple dwellings situated in Gatineau Park, they have been generated to be mindful of their complex phenomenological potential with an understanding of the park and the users who will experience them. Through the examination of both quantifiable means and a conscious understanding of the environment (from all perspectives), the result is a series of three separate pavilions forming a circuit of discovery within Gatineau Park while acting as hubs for the interpersonal exchange between researchers and visitors who gather to experience and understand the park in a heightened method.

Overall, phenomenology plays an important role not only in architecture but also in our understanding of time, place, and site - as experienced. It enables the uncovering of layers of information that are not only scientific but also existential. Phenomenology helps frame our bodily experiences as well as our understanding of our environment on a deeper conscious and subconscious level. 



\section{Program}

'Everything is connected to everything else' can be a salutary political reminder that whatever we do has wider implications than perhaps we commonly recognize.

\section{- Doreen Massey}

For Space
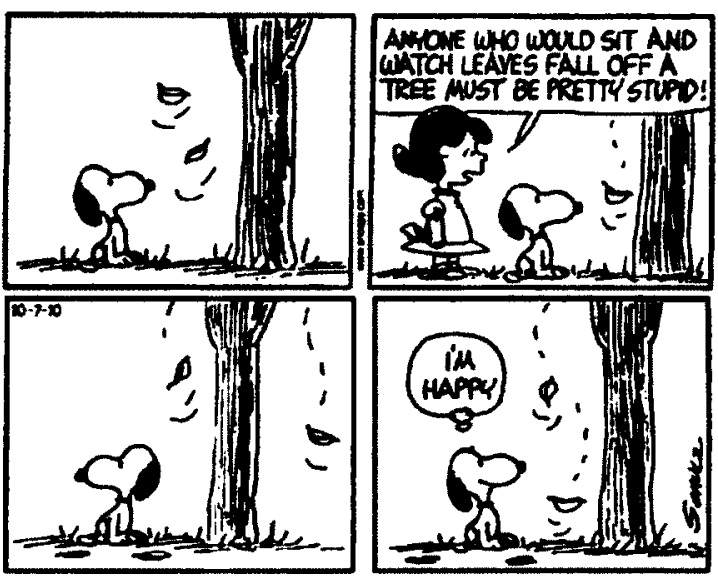


\section{Design Intent}

Good design does not exist alone; it is developed out of a precise examination of its natural and manmade surroundings.

- Richard Horden ${ }^{27}$

The design component of the thesis focuses on a series of three pavilions for visitors and researcher to gather at, while promoting conservation, scientific research and education in Gatineau Park. They utilize a material palette that relates to the site and evokes a sense of semitransience through their construction method. These pavilions have the ability to be deconstructed and relocated to different areas of the park. They provide researchers with a hub for collecting information about the park and a place for visitors to learn. The design of each pavilion is based on the natural landscape while framing the importance of a sensual architectural experience.

The pavilions function as educational centers about the park and provide spaces to perform scientific research. By using the site to influence the design, the pavilions express the importance of developing architecture through a thorough understanding of a site's historical, physical and cultural context. This process aims to illustrate how different formal responses can be generated from this understanding. 
The importance of designing a site-specific architecture is demonstrated through the development of a series of three pavilions within Gatineau Park. As Pallasmaa says in The Eyes of the Skin "we can dream and sense our being outdoors, but we need the architectural geometry of a room to think clearly. The geometry of thought echoes the geometry of the room." ${ }^{28}$

28 Juhani Pallasmaa. Eyes of the Skin: Architecture and the Senses. Wiley Academy: Chichester; John Wiley \& Sons Ltd.: Hoboken, NJ , 2005. 45. 

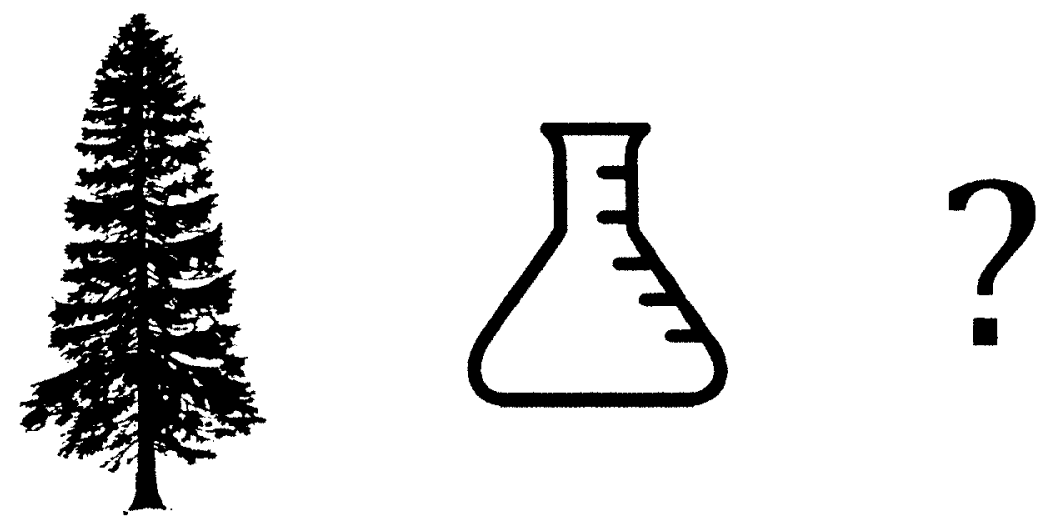

"The most beautiful experience we can have is the mysterious. It is the fundamental emotion which stands at the cradle of true art and true science. Whoever does not know it and can no longer wonder, no longer marvel, is as good as dead, and his eyes are dimmed."

- Albert Einstein,

"The World As I See It" 


\section{Pavilions as a Design Tool}

As architecture becomes smaller, [...] it comes closer to the people who are meant to use it. Materials and details become more important and require more attention.

-Richard Horden ${ }^{29}$

The term pavilion is defined as a building or similar structure used for a specific purpose ${ }^{30}$ It is derived from the Latin word papilio(n-) meaning "butterfly" or "tent". The French translation, pavillon, is defined as an isolated structure situated on a property or park. ${ }^{31}$ From the definitions and origins of the word, this type of architecture is appropriate for the design of the micro architecture proposed in this thesis for Gatineau Park. These pavilions capture a sense of temporality and isolation from the city in a natural environment. Furthermore, they demonstrate the potential for growth, change and development in the years to come.

In general, a pavilion is the ideal architectural form for attempting to translate and test architectural theories. It enables the architect to hone-in on a single element and to develop the concept by attempting to resolve all related queries. By setting a restriction on the size of the dwelling, one can

Richard Horden. Micro Architecture. Thames \& Hudson Ltd.: London, 2008. 100.

30 Oxford University Press. "Pavilion." (2012) 21 Dec. 2012.

<http://oxforddictionaries.com/definition/english/pavilion?q=pavilion>.

31 Larousse. "Pavillon." (2008) 21 Dec. 2012.

<http://www.larousse.com/en/dictionaries/french/pavillon/58800>. 
focus on the details that support the architecture to generate a complete sensory work that can be enjoyed by a diverse group of individuals.

Alberto Pérez-Gómez highlights this idea in his article "Polyphilo's Thresholds: Alternatives for Nomadic Dwelling." He says:

As architects or designers we are called to envision a better future, our projects necessarily retain a utopian vector as part of their ethical dimension. Whether we design an ephemeral or a permanent structure, this ethical imperative is primary. In order to embrace it, we must understand that the ephemeral object must simultaneously offer a dwelling place and therefore, paradoxically, be memorable. And this is indeed the difficulty. Ephemeral architecture needs to be critical in the same measure as, say, the architecture of a museum: opening our being to death, while celebrating our human capacity to think the eternal. It doesn't do this merely by being technically responsible, built with light or recycled materials. For human life, even at its most precarious, seeks play and well-being, and never merely survival. ${ }^{32}$

These concepts of ephemeral architecture help support the pavilions' designs. The ability to challenge the sense of permanence and grounding of a structure is achievable through the pavilions' firm material detailing. Additionally, by locating these pavilions within a complex natural environment, it enforces the idea of play through discovery and interaction. Furthermore, the pavilion is the appropriate scale for the environment in which it is designed for.

32 Robert Kronenberg, ed. Transportable Environments 3: Theory, Context, Design and Technology. Taylor \& Francis: London, New York, 2006.3. 
Richard Horden in Micro Architecture explains this concept of smaller architecture quite eloquently. He says, "The idea is to create a temporary place, to touch the Earth lightly. It is about a see-through and transparent architecture, architecture that enhances the beauty of nature without compromising it." ${ }^{33}$ And this is precisely what these pavilions accomplish. They enhance the natural environment by using the natural landscape as inspiration for their design.

33 Richard Horden. Micro Architecture. Thames \& Hudson Ltd.: London, 2008. 99. 

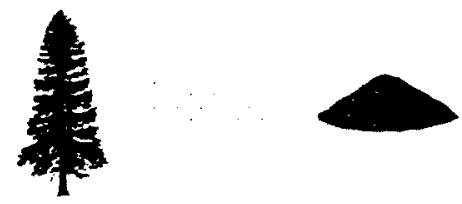

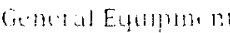

- but - The piste

- pripection

- drimetsingen

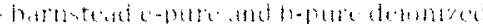
sidter sistem

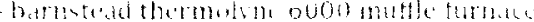

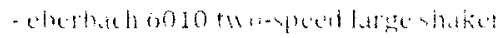
lanthe

- eppenders 3810 controtuge

- hatres sterilemas futhise

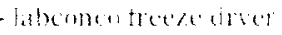

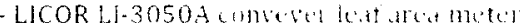
mettler halance

- patckind tri-tath 2100 TR xinulation cinuntel

- thizuleat reanmel

- spectronk 600 upectmphorumeter

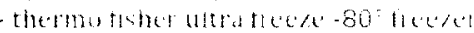

- LICOR Li-s 100 kat allat me thi

- WinfOLIA leut atren meter
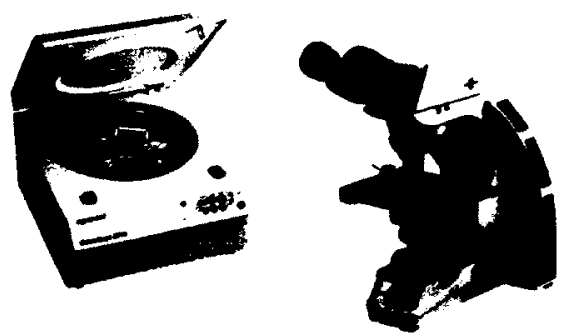

Busting pores

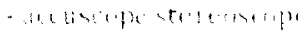

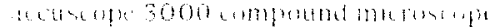

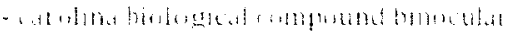

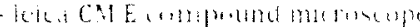

- Untion aterensiape

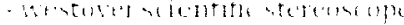

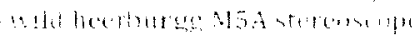

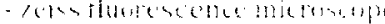

Incubetion fiatlity

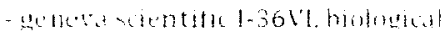
molutiats

- water bath chamber

Fiedal Equipment:

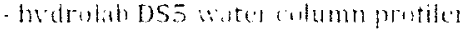

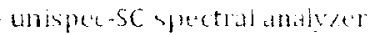

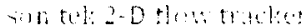

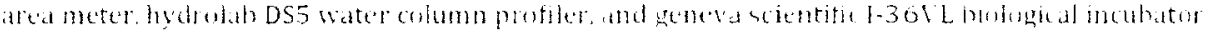
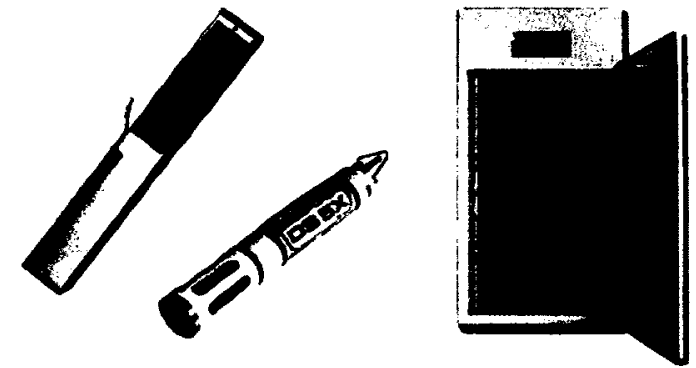

This is a list of scientific tools taken from the Toolik Field Station's website. They are an Environmental Data Centre located in Fairbanks, Alaska. 


\section{Assembly}

Though we take a great deal of inspiration from nature, we also look to other areas of production and technology to help us achieve the best combination of form and function.

- Richard Horden ${ }^{34}$

The assembly of the pavilions utilizes the concept of a "kit-of-parts." This facilitates the ability to dismantle the pavilions and relocate them to different regions within the park, emphasizing their temporal nature. Thus, the pavilions can be relocated to more optimal areas within the park to collect scientific data and/or to heighten the experience of particular natural features. The flexibility of this kit also enables the structures to be reconfigured to accommodate different program sizes and it allows them to respond to specific site contexts.

The post and beam construction lends itself easily to this theory and was selected for this reason. It utilizes wooden members joined together with metal connectors. ${ }^{35}$ These metal connectors are attached to the wood members with screws and slide together to create a seamless joint. Overall,

34 Richard Horden. Micro Architecture. Thames \& Hudson Ltd.: London, 2008. 35.

35 There are many different metal connector options available today. For example, the company Sherpa offers a product that utilizes a two-part metal connector system that slides together. It facilitates quick assembly and disassembly when required for structural systems. 
this system enables the pavilions to be disassembled and reassembled in various locations while enforcing the concept of temporality.

Even the sliding panels that clad the structures follow a similar strategy. The panels themselves are attached to the post and beam construction with a track. This enables the panels to be removed and replaced with ease. The panels act as a base for the exterior cladding. In order to illustrate their thematic link, a material is applied to their face. For example, horizontal wood strips are applied to the face of the panels on the Tree Pavilion to represent tree branches.

There is also a sunshade that can be applied to the exterior of the structure. It consists of a round metal bar that can be attached to the pavilion's vertical structure through a metal plate and some screws. Once this is secure, exterior grade canvas fabric panels slide onto the metal bars, suspending the panels in front of the pavilion and generating temporary sunshades when required by the pavilions' users.

Overall, the pavilions utilize a "kit-of-parts" assembly to enforce the concept of temporality. The ability to easily dismantle and relocate the pavilions to different areas of the park, as well as modify their layout, enforces these ideas of a temporal architecture. 


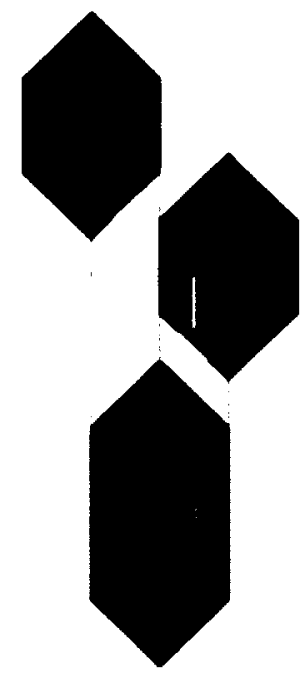

Strutural Arembir

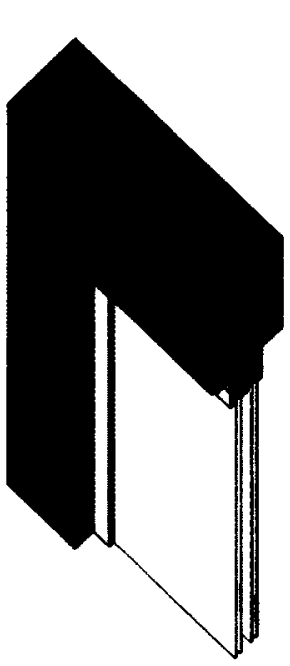

Shaling Panch

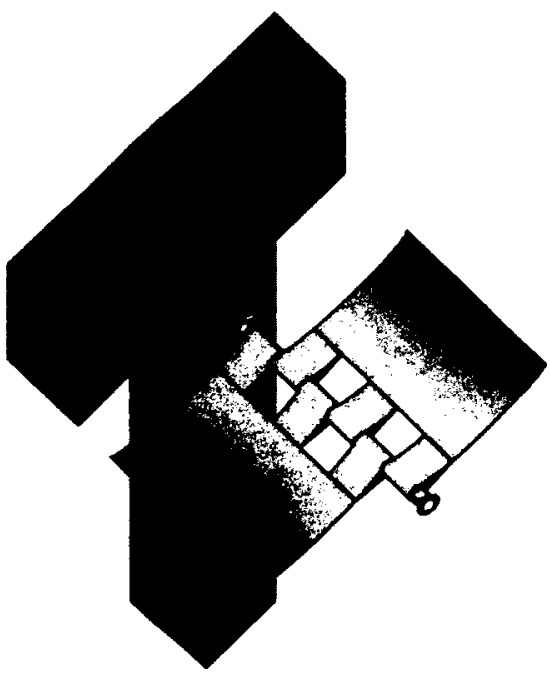

Sun Shate

\section{Kit-of-Parts Assemblies}




\section{Services}

Although the majority of the samples and measurements of climatic and organic changes performed by the researchers are considered to be "basic," occasional overnight stays (or extended visits) may be required to complete scientific research. As a result, the typical comforts of an urban dwelling are required to facilitate their research and make their stay more

pleasurable. Since the pavilions are located in a remote environment, they rely heavily on alternative means for electricity, water, sewage, and temperature control, not only to perform basic tasks but also to provide comfort for the dweller.

Electricity for the pavilions is generated from a solar panel system. The panels are applied to the south facing roofs of the structures for optimal sun exposure. This provides the electricity required to perform simple tasks such as charging a computer to input data.

Clean drinking water will be brought to the site with the researcher. However, rain barrels will be utilized to collect water from rainfalls and its contents used for other everyday tasks. Furthermore, with all three pavilions currently proposed along the shores of Meech Lake, the ability to transport water using a simple bucket can complement or supplement the rainwater collection system.

For sewage, composting toilets will be utilized in the pavilions' washrooms. Their current design and development has progressed 
significantly from the days of the traditional outhouse. According to composting toilet manufacturer Sun-Mar's website, traditional toilet waste is $90 \%$ water content ${ }^{36}$ A compostable toilet reduces this number significantly by breaking down human waste into useful fertilizer soil. ${ }^{37}$ Furthermore, they are odour free.

Temperature control is a primary concern regarding individual comfort as well as specimen containment. In this particular case, heating the structure during the winter months is important for longer stays. Heaters attached to propane tanks can heat the structure during this time. According to Northern Tool + Equipment's website, their Mr. Heater Tank-Top Propane Heater attached to a $20 \mathrm{lb}$ tank can last between 30 to 52 hours, ${ }^{38}$ making them suitable for the short term stays. In order to keep any specimens or collected samples chilled for a short period of time, the use of a small propane fridge will be installed. Furthermore, a small propane stove will also be installed for cooking meals. Ibid.

38 Northern Tool + Equipment. "Mr. Heater Tank-Top Propane Heater." 1 May. 2013. <http://www.northerntool.com/shop/tools/product_200485295_200485295>. 


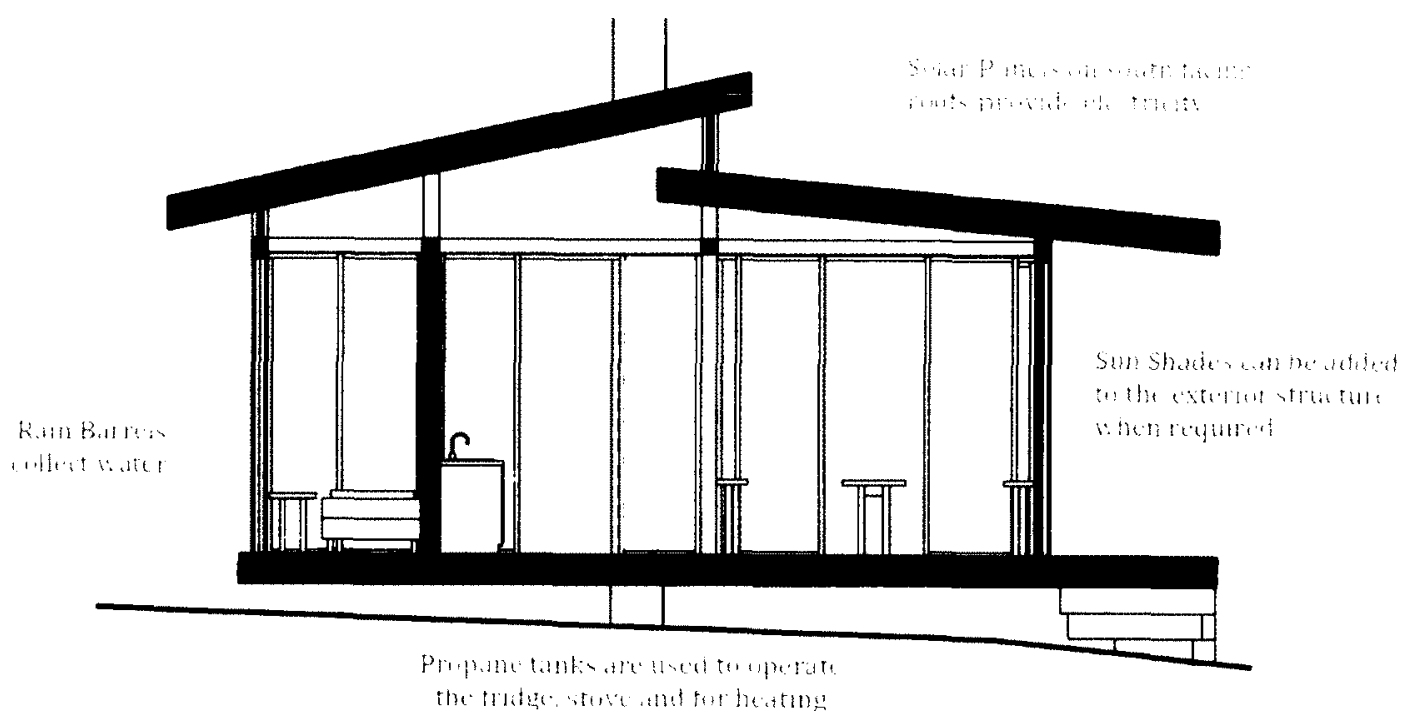

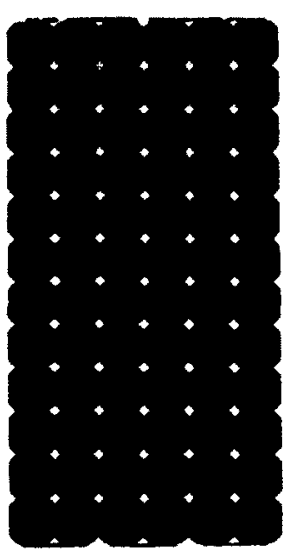

Electricity

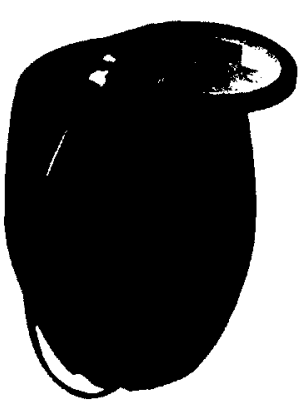

Wate:

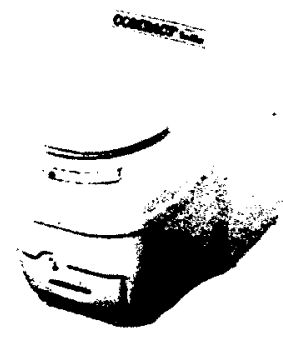

Selvige

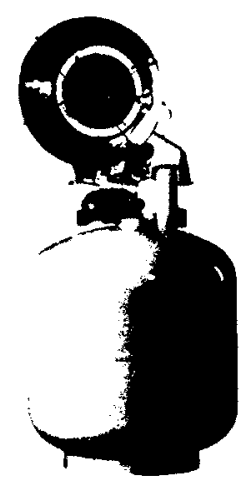

Temperatume Contrat

Site Services 



\section{Process}

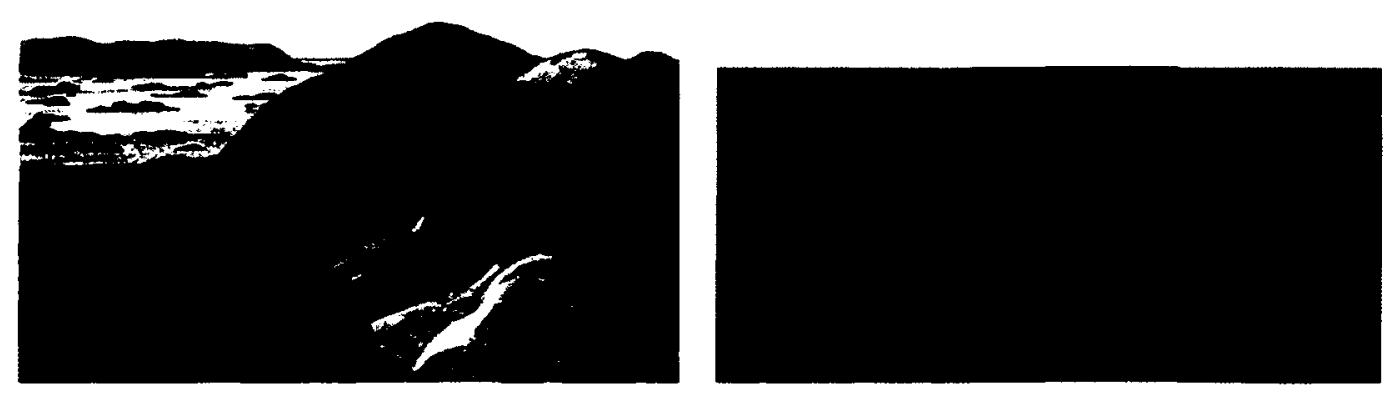

Reima Pietila, the Finnish Architect, compared the design process with the acts of hunting and fishing; you cannot be certain what you are going to catch, or whether you will catch anything at all.

- Juhani Pallasmaa,

The Thinking Hand 


\section{Overview}

Whether it be poring over maps, taking the train for a weekend back home, picking up on the latest intellectual currents, or maybe walking the hills ... we engage our implicit conceptualizations of space countless ways. They are a crucial element in our ordering of the world, positioning ourselves, and others, human and nonhuman, in relation to ourselves.

- Doreen Massey 39

The design component of this thesis developed a series of three pavilions within the NCC's Gatineau Park that operate as educational centers for visitors as well as research stations for scientists. By designing a structure that serves dual purposes, it addresses the challenges of designing from a site whilst fulfilling programmatic criteria that is appropriate to its context.

Instead of solely relying on a single method of observation to generate the design, a traditional "hand measured" survey was initially produced using a tape measure and triangle to generate a mapping of the trees on the hill as well as a virtual mapping of the site was conducted to understand the larger context. It is from the direct and intimate understanding of the hand drawn trees' locations that generated the floor plan of the first pavilion - and set the parameters for the other two iterations.

39 Doreen Massey. For Space. SAGE: Thousand Oaks, Calif., 2005. 105. 


\section{Understanding Gatineau Park}

Maybe our current, 'normal' Western maps have been one more element in that long effort at the taming of the spatial.

- Doreen Massey 40

In order to understand the landscape that comprises Gatineau Park, multiple strategies were used. This includes the hand-drawn site mapping of the trees' locations, the experiential sense of the park when traipsing along its trails, and a digital mapping of the site that could be manipulated and observed in a virtual realm was vital. This relates back to the importance of body intellect and how when it is used harmoniously with a site it generates a better understanding of context. As a result, a map generated from the Geographic Information System (GIS) provided by Carleton University's Library was used to comprehend the site from this virtual perspective. ${ }^{41}$

The GIS map used to examine Gatineau Park contains points with individual $x, y$, and $z$ coordinates. The ability to rotate the site and view the landscape from different angles enabled a more thorough understanding of

40 Doreen Massey. For Space. SAGE: Thousand Oaks, Calif., 2005. 106.

41 A GIS is a computer system capable of assembling, storing, manipulating and displaying geographically referenced information. They vary in form and file types that include geographic points, topographic lines, aerial and satellite images. 

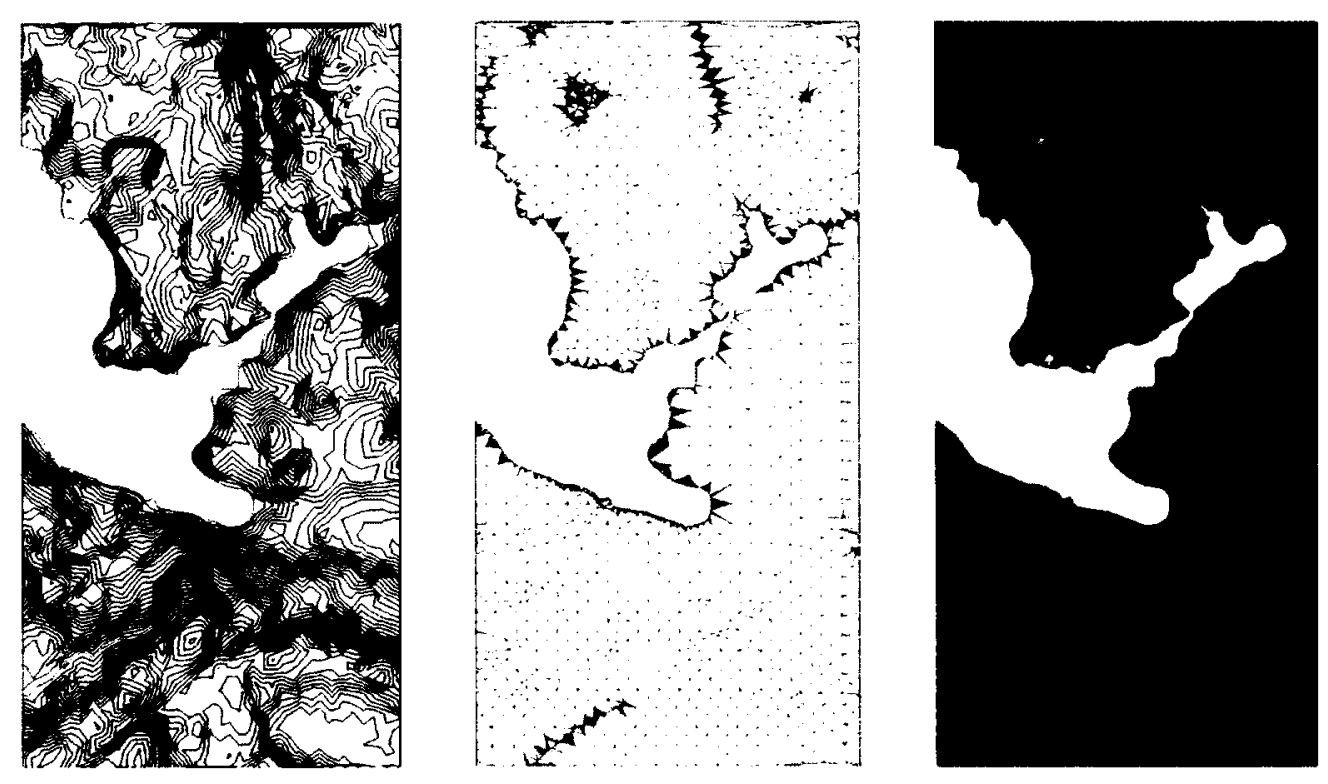

Gatineau Park Topography 
the planes and contours that make up not just the site but also the park as a whole.

In this particular case, the geographic reference points were used to generate a topographic landscape in Revit. This facilitates an understanding of the landscape's elevations and surrounding site context. In order to generate this landscape as a topographic element, two different files of data were assembled because the site was located near the edge of two separately mapped regions. Once the two maps were stitched together, the information was exported as reference points into an Excel file. This file was then cleaned up to only include the $x, y$, and $z$ coordinates of the points. Then the Excel file was imported into Revit to generate the landscape as a toposurface. Overall, by generating a landscape through the information provided, a new level of comprehension regarding the landscape's contours was achieved. 


\section{The Journey}

Nothing behind me, everything ahead of me, as is ever so on the road.

- Jack Kerouac ${ }^{42}$

During the foundational years in architecture school, students are taught the importance of circulation. An architectural path has a narrative quality that can be told by guiding people through a space. This circulation through a building, beyond facilitating egress, can generate a narrative about the structure. The way in which people circulate through a building choreographs their journey.

Yet, in many situations this journey begins long before the arrival to a place. The first step is the spark in one's mind to visit it - from there the journey begins. It is the path one takes to and through the space that makes the journey, and the afterthoughts from the narrative, which are embedded in our memories.

The journey to the pavilions may begin at any fixed geographic location. In this personal narrative, the journey begins at the Azrieli School of Architecture and Urbanism in the city of Ottawa. The path to the site is carved on city streets that weave through the city of Ottawa to highway $5 \mathrm{~N}$ in Hull, Quebec. After a short drive the highway is abandoned for a road (in

42 Jack Kerouac. On the Road: The Original Scroll. Viking: New York, 2007. 
much need of repair) called Old Chelsea Road. The vehicle bumps along this road as it twists and turns through the hilly landscape until it reaches the parking lot for Meech Lake. The next part of the journey takes place along a hiking trail on foot.

A dirt path, labeled Trail 36, carved out of the landscape leads to the final destination. The path moves up and down the hilly landscape, over a bridge and forks in the middle of the woods. In front, the path continues along the undulating terrain. To the south, the shores of Meech Lake are visible beyond the pavilion. This is the chosen path.

The path descends gently towards the water. To the east of the path is a small hillside where a pavilion rests. Along the southeast side of the pavilion is a path already carved out of the landscape, leading to the entrance of the building. Once inside the pavilion, there are various displays and exhibits waiting to be interacted with and purposely creates a pause before the journey is continued.

From here, the journey continues along Trail 36 to discover other destinations within the park. The sense of carving a path in one direction eventually to retrace these steps helps to embed the memories created from the journey. This recollection of memories helps identify important elements along the trails and our sense of place in the world. 
Bad day looking for a way home, looking for the great escape. Gets in his car and drives awav: far from all the things that we are. Puts on a smile and breathes it in and breathes it out, he says,

bye bve bye to all of the noise.

Oh. he says, bye bve bye to all of the noise.

\section{- Patrick Watson,}

"The Great Escape"

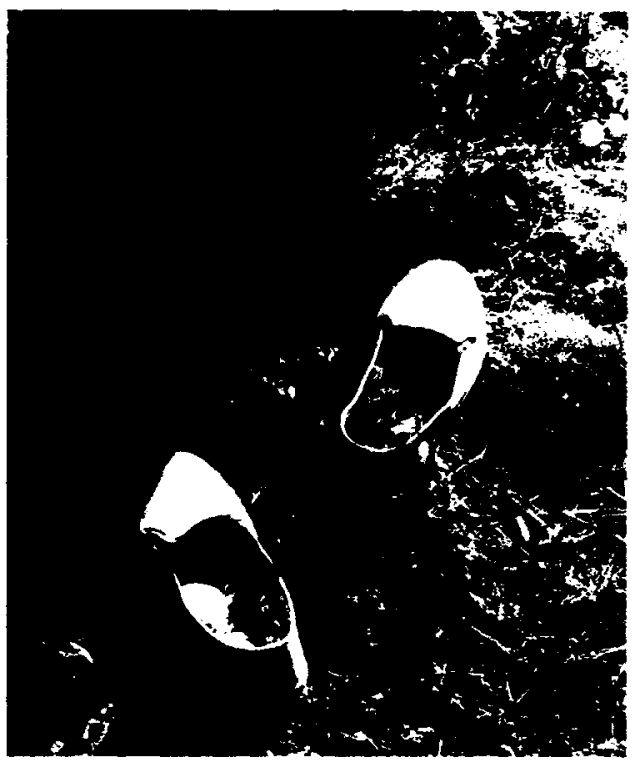





\section{Materiality}

The tectonic language of architecture, the inner logic of construction itself, expresses gravity and structure, the language of materials as well as processes of construction and details of joining units and materials to one another.

-Juhani Pallasmaa,

The Thinking Hand

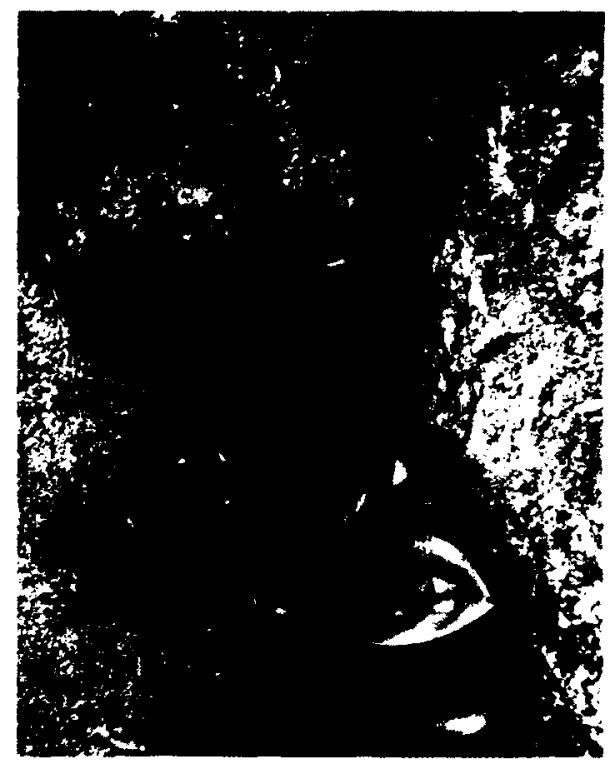




\section{A Palette for the Senses}

Natural materials - stone, brick and wood - allow the gaze to penetrate their surfaces and they enable us to become convinced of the veracity of matter.

- Juhani Pallasmaa ${ }^{43}$

The pavilions incorporate a material palette that is reflective of their site. Natural indigenous materials including wood, metal, stone and glass are used in a complementing manner. As a result, this achieves a sense of temporality in the structures and a connectedness through its material assembly.

The material palette selected influenced the designs. This relates back to concepts discussed in the written works of Juhani Pallasmaa, Alberto Pérez-Gómez and Marco Frascari that emphasize the importance of materials for sensual architecture. As a result, the designs utilize a material palette that is warm, tactile, and inviting. By understanding the site, both from a physical and non-physical point of view, the material palette connects the pavilions to the landscape.

Wood is the primary material used in the designs. It is used both for the structural framing of the pavilions, cladding and detailing. This material was selected because of Canada's long-standing history of utilizing wood

43 Steven Holl, Juhani Pallasmaa and Alberto Pérez-Gómez. Questions of Perspective:

Phenomenology of Architecture. a+u Publishing Co., Ltd.: San Francisco, CA., 2006. 29. 
frame construction methods. Furthermore, using wood in the designs solidifies the relationship between the pavilions and the densely forested landscape. It also connects to the park historically that suffered extensive logging practices during the $1800 \mathrm{~s} .{ }^{44}$ The versatility and importance of this material is highlighted in the proposed designs.

Metal is used in the designs in conjunction with the wood structures by highlighting their points of connection. It was selected to emphasize the importance of minerals within Gatineau Park. Similar to the trees in the area, during the 1800 s the park was excavated in areas for mining. ${ }^{45}$ By using metal in the material palette, it emphasizes the site's historical and cultural factors through the pavilion.

Stone elements are incorporated into the designs to connect the pavilions with the site's rocky terrain. This is to emphasize the geological history of the site. Large sheets of ice used to cover the Ottawa-Gatineau region but as the earth began to warm the ice started to melt. ${ }^{46} \mathrm{As}$ a result, the rock formations in this region, both large and small, were carved and polished by the shifting ice sheets. ${ }^{47}$

Glazed sliding panels are used in the design to open the pavilions to the surrounding landscape. This enables the exterior/interior barrier to be eliminated and facilitate the connection of the pavilions to the site. By enabling the pavilion to open up to the landscape it helps facilitate scientific monitoring from within the pavilion. Furthermore, the use of sliding panels enables the structures to ventilate naturally as air circulates through them.

44 Canadian Parks and Wilderness Society. Gatineau Park: A Threatened Treasure. 2008. 11

45 Ibid, 11

46 Natural Resources Canada. "Changing Landscape". (2008) 23 Mar. 2013. <http://www.nrcan.gc.ca/earth-sciences/products-services/mappingproduct/geoscape/ottawa/6275>.

47 Ibid. 
By focusing the material palette on "natural" and locally sourced materials that reflect the site, a stronger relationship between the pavilions and the landscape is enforced. This means the culture and history of Gatineau Park are translated to the pavilions' visitors and users in both an explicit and implicit manner. 


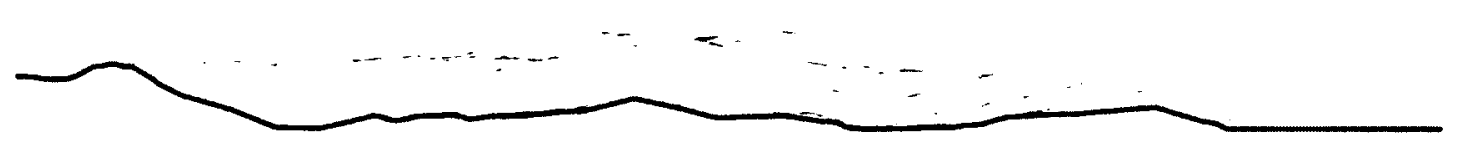

Gathoun Path Landeralle

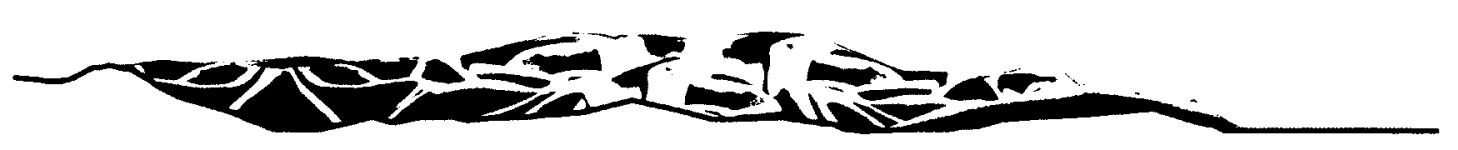

Garmata Parli Fabric

\author{
Gatineau Park Landscape vs. Fabric
}




\section{Wood}

Wood is used as the primary material in the designs. This is to synthesize the pavilions with the site's dense tree coverage. Pine is used for all three pavilions' structural framing. White cedar is used for smaller detailing within the pavilions (ie, furniture, wall paneling). This illustrates the importance of the cedar species within the park. The Eardley Escarpment, partially located within the southern region of Gatineau Park, contains more than $80 \%$ of the Eastern Red Cedars inventoried in Quebec. ${ }^{48}$ However, according to the NCC, the Eastern Red Cedar is considered an endangered tree that they are protecting within the park. ${ }^{49}$ Yet, by using wood as the primary structural design medium, it emphasizes the connection to the landscape.

Wood is also considered a more environmentally friendly option. It requires no heavy machinery to work with, it's cost effective, easy to manipulate, and widely accessible. As a result, utilizing wood products in the designs is the best way to address issues of tactility.

48 National Capital Commission "Eardley Escarpment" 23 Feb. 2013. <http://www.canadascapital.gc.ca/places-to-visit/gatineau-park/eardley-escarpment>. 49 Ibid. 


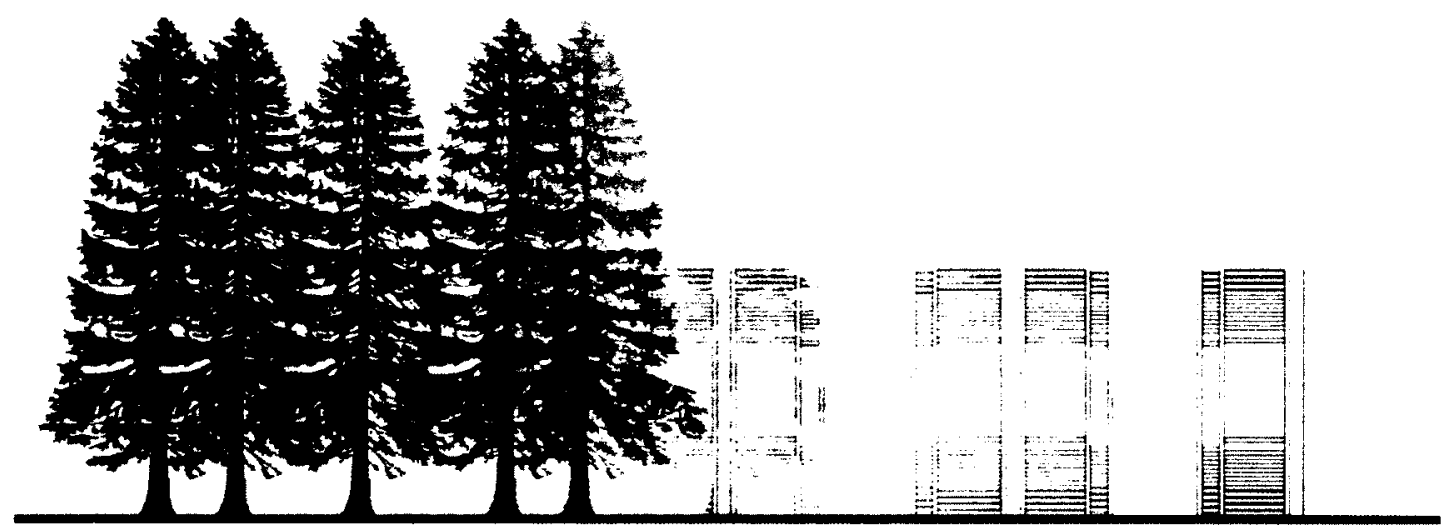

Morphing Trees 


\section{Metal}

Various metals are used in the pavilions. Brass and copper detailing are used in smaller components to embellish the wood structure (ie. door hardware). Additionally, a corrugated steel roof system is used to shelter two of the pavilions. These metals were selected to emphasize the mineral rich Precambrian rock and the Eardley Escarpment that lies within Gatineau Park.

The Tree and the Water pavilions use a corrugated steel roof system to protect the structures. Each piece gently slopes to shed water and to mimic the landscape's planes and hillsides. Furthermore, the metal amplifies the sounds of nature when they interact with it. This means that when it rains, or when trees shed their leaves, acorns, and branches, the metal roof system amplifies the sound inside the pavilions. This simple gesture establishes a connection to the landscape through sound. 


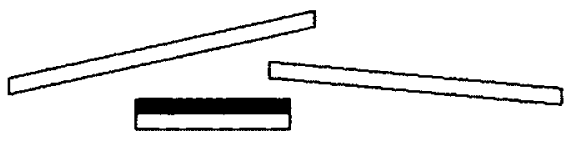

Bien Ruthis

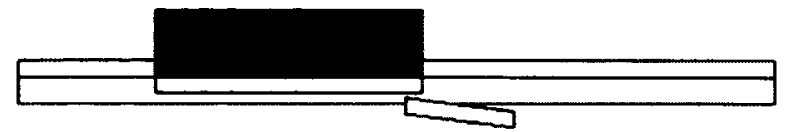

Wuth Rositluhe

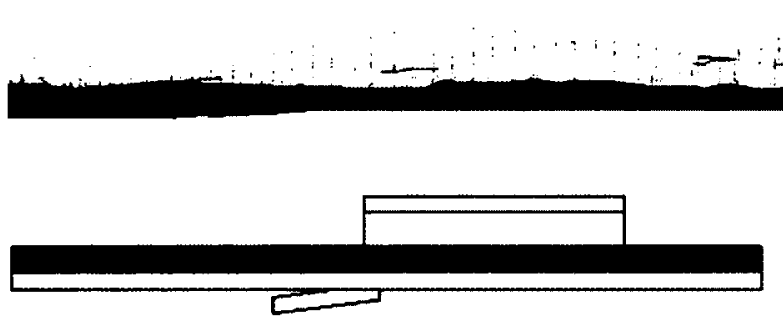

Sisth Rubline

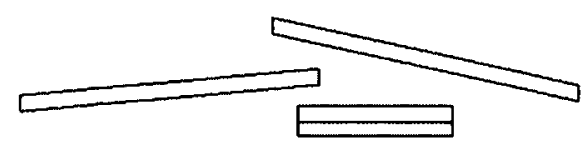

Eust Rowilutio

Rooflines 


\section{Stone}

Stone is used primarily in the Earth Pavilion. Various types of small rocks are used in the glazed panel system while stone roofing tiles are used to shelter the pavilion. The use of stone emphasizes the three different terrains that make up the landscape. These include Precambrian granitic and metamorphic rocks of the Canadian Shield, the flat-lying Paleozoic rocks, and the Quaternary sediments that cover the area. ${ }^{50}$ Together, these layers generate the mineral rich landscape of Gatineau Park.

50 Natural Resources Canada. "Different Rocks." (2008) 23 Mar. 2013. <http://www.nrcan.gc.ca/earth-sciences/products-services/mappingproduct/geoscape/ottawa/5989>. 

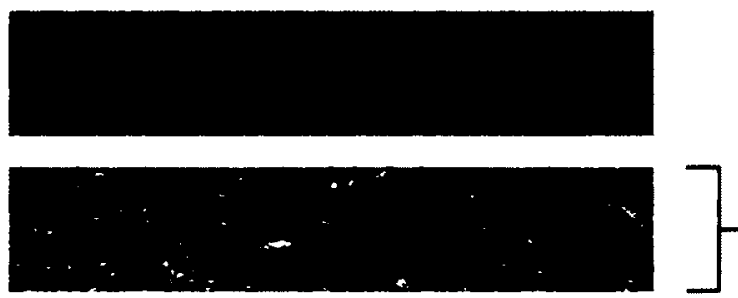

OHatramer.

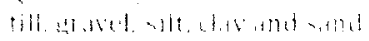

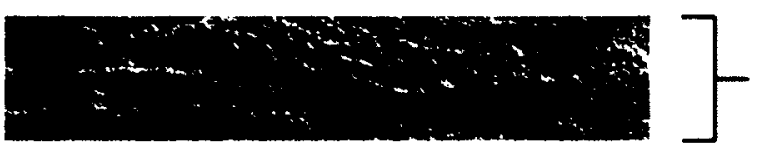

Pillowente

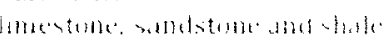

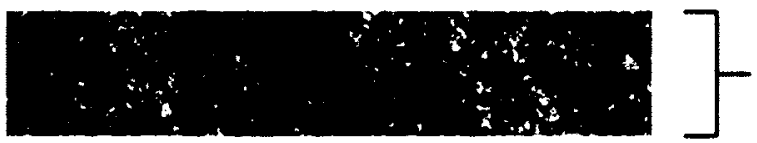

Prexamblats

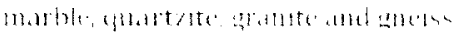

Rock Layers 


\section{Transparency}

Achieving a sense of transparency in the pavilions is important to eliminate the sense of enclosure. As a result, the pavilions' vertical cladding system consists of glazed sliding panels each designed with slight variations. This produces a structure that is visually open to the exterior at all times. Even when the panels are "closed," their transparency creates a sense of openness to the landscape.

Variations on the cladding systems depend on the theme and function of the pavilion. In the Trees Pavilion thin strips of wood are applied to the interior surface of the panel. This is to mimic the branches of the trees that fill the landscape. In the Water Pavilion cast glass panels are used. This is to mimic the motion of a ripple effect on the water from a macro scale. And lastly, in the Earth Pavilion gravel, dirt, and small vegetation are placed between the exterior face of the glass panel and wire screening. This is to blend the structure with the ground and existing landscape. 


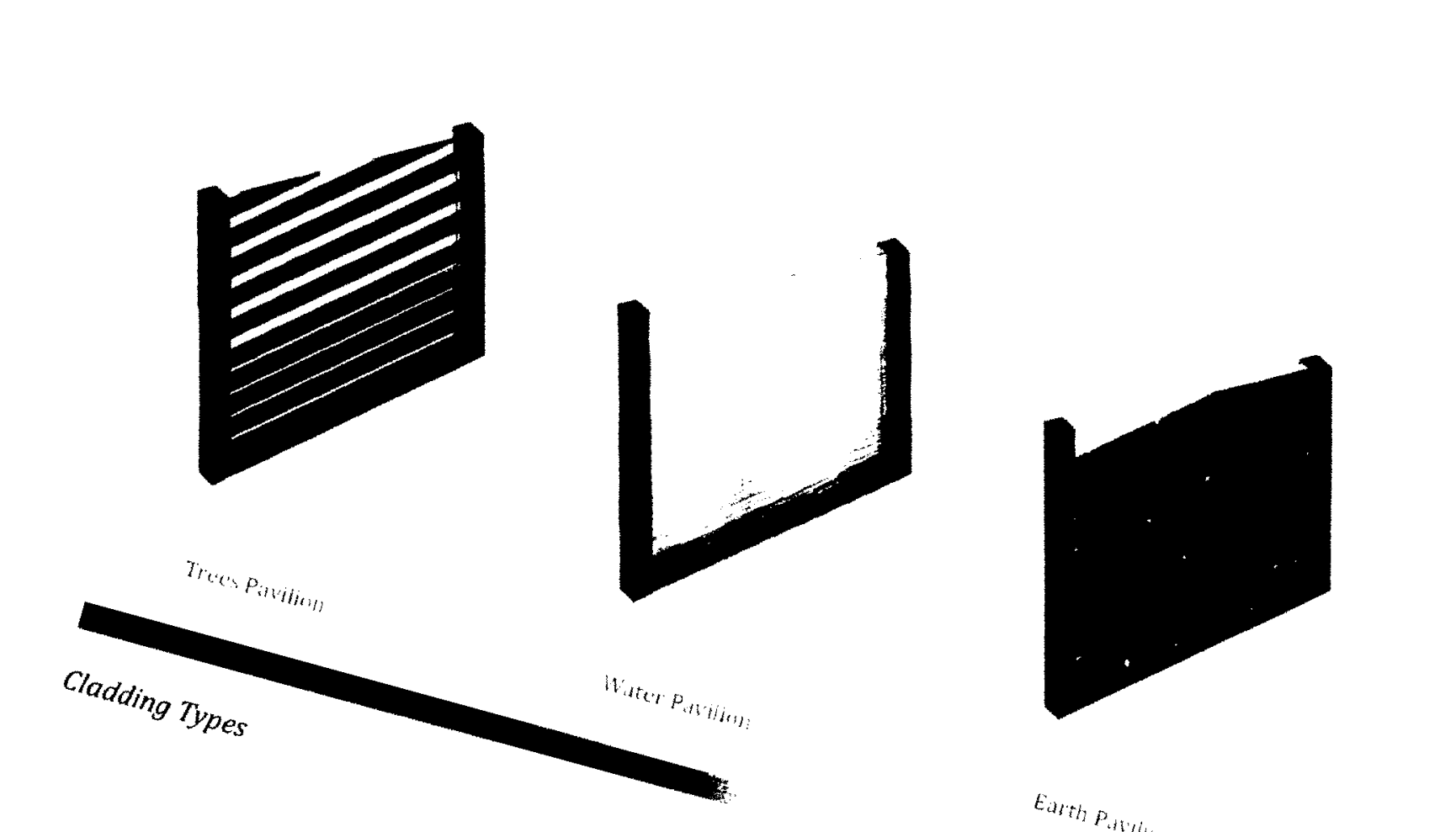





\section{Design}

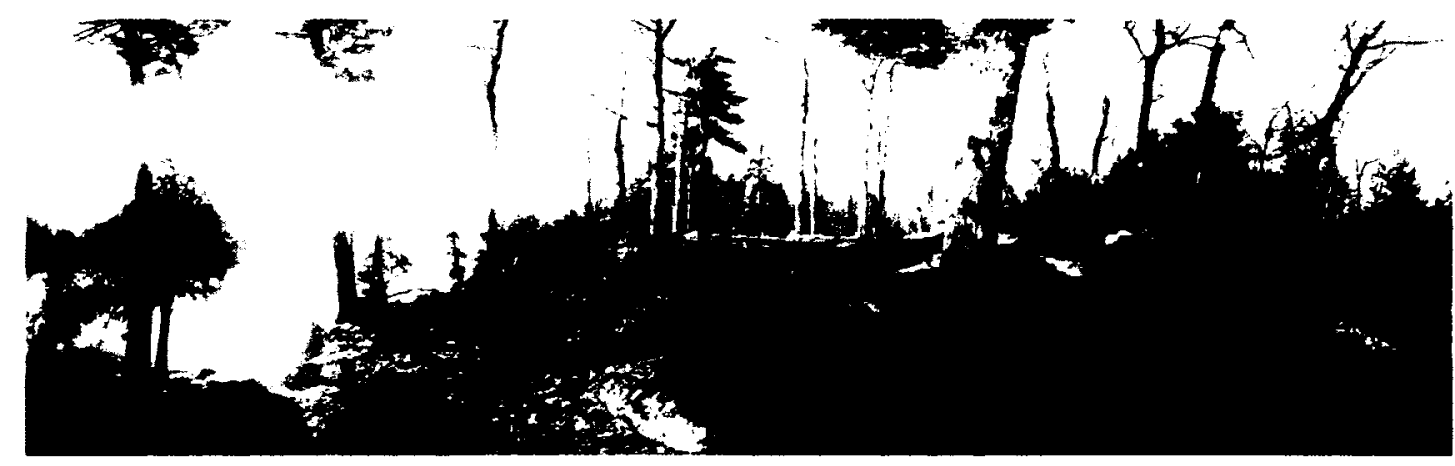

The challenge for architecture is to stimulate both inner and outer perception; to heighten phenomenal experience while simultaneously expressing meaning: and to develop this duality in response to the particularities of site and circumstance.

- Steven Holl,

"Questions of Perception: Phenomenology of Architecture" 


\section{Designing for Gatineau Park}

0, mes chemins et leur cadence

(Oh, my roads and their cadence)

-Jean Caubère ${ }^{51}$

The design was developed through various word mappings, physical sketch models, sketches, digital mappings, and digital models. There were also various works of literature, visual works of art and cinema, and auditory tracks during this development phase that inspired the design process. Altogether, they produced the final result that is a series of three pavilions located within the NCC's Gatineau Park. The pavilions' designs, as illustrated below, are the result from this multi-layered process.

The word maps were used in the preliminary stages of the design process. This helped to understand the origins and connections between the words related to vernacular dwellings (ie. cottage, cabin, and camp). An etymological understanding of the roots of these words helped to reinforce the base design features. This includes the scale of the project as well as the programmatic function of the pavilions.

From the word maps, examples of micro vernacular dwellings realized by architects and non-architects were observed to help generate a form. For

51 Gaston Bachelard. The Poetics of Space. Beacon Press: Boston, 1969. 11. 


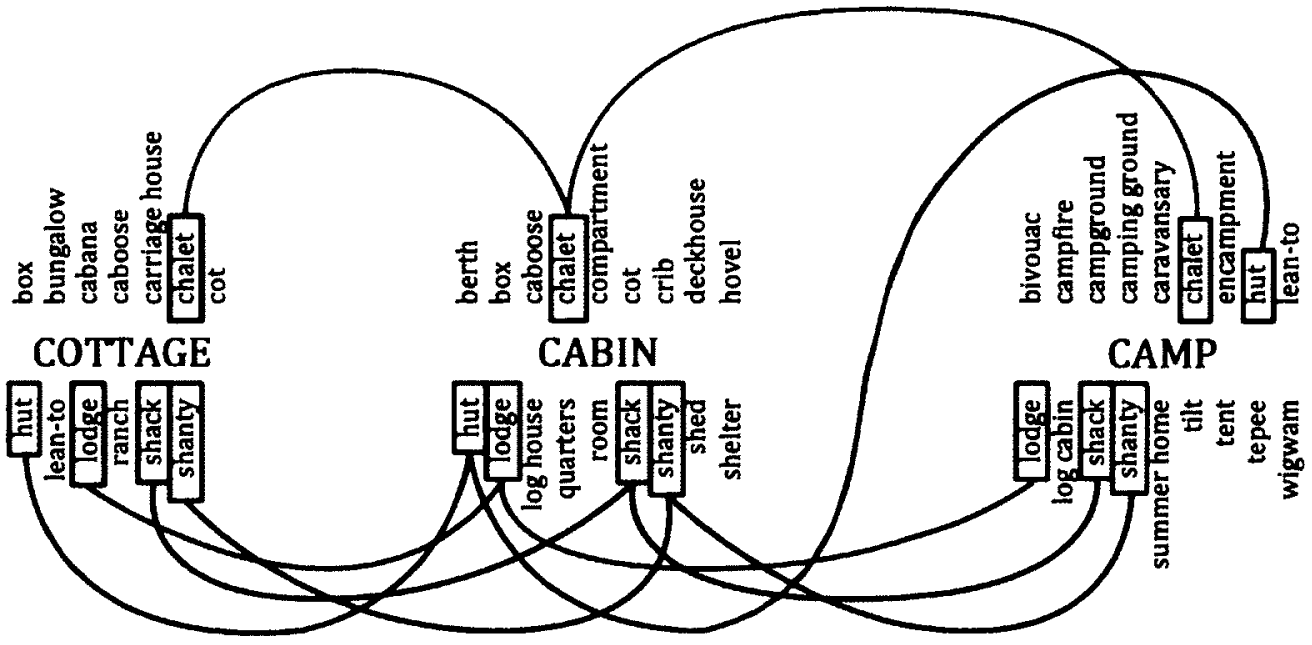

CHALET

A wooden house with overhanging eaves, typically found in the swiss alps

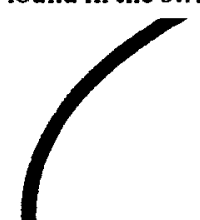

COTTAGE

A small house, typically one in the country

HUT

A simple, small, single storey house or shelter

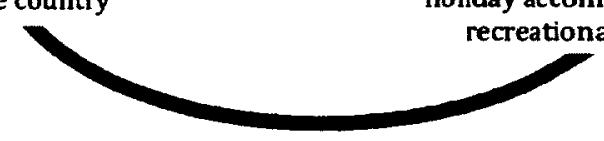

CABIN

A small wooden shelter or house in a wild or remote area

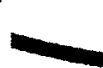

LODGE

A small country house occupied in season for sports such as hunting, shooting, or skiing

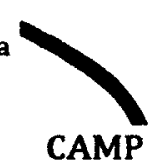

A complex of buildings for holiday accomodation, with recreational facilities

SHACK

$A$ roughly built hut or cabin

SHANTY

A small, crudely built shack

Mind Map 1

Mind Map 2 
example, Herbert Enns' Experimental Cabin at Shoal Lake is an instance of a vernacular dwelling that supports the concepts in this thesis. The cabin is located on a 24 -acre $\left(0.1 \mathrm{~km}^{2}\right)$ island that requires a $3-$ mile $(4.8 \mathrm{~km})$ journey by boat from the mainland. ${ }^{52}$ Enns' goal was to construct something using recycled materials, without the use of power tools, and to cost no more than $\$ 1,000 .^{53}$ The result is a successful two-cabins design (one for sleeping and one for eating) that was constructed using very minimal resources in a challenging environment. His utilization of a simple design and limited materials (wood, metal, glass, and corrugated plastic) fulfills the purpose of sheltering inhabitants from the harsh climate variables. These cabins illustrate the possibilities to construct a dwelling in a remote environment with few tools and locally sourced materials in order to generate a successful design that responds to the landscape in a sensitive manner.

A site based design strategy necessitated a modeling approach to the design. Crude site and concept models were constructed out of cardboard to articulate concepts and to understand the potential of the physical site. Each produced a different form, all striving to achieve the same objective: the design of a small vernacular dwelling in the woods. Their influences, if not formal, lay in their demonstration of scale, situating and the potential programmatic layout. During this crude modeling process, sketches were also drawn up to test formal ideas and detailing that has influenced the final designs.

From the sketches and physical models, a site model was built in Revit to start the digital modeling process. It is in this digital platform that the designs were finalized. This was achieved through various iterations of the models to propose the best possible solution for each case. Modeling in Revit

\footnotetext{
52 Deborah Bishop. "Barely There." (Jul/Aug 06) 21 Dec. 2012. <http://www.dwell.com/articles/barely-there.html>.

Ibid.
} 
In each case, an overarching interest in "pairing back" refreshes our sense of how to live modestly in the world while serving as laboratory and source of inspiration.

- Christopher Macdonald, Cabin, Cottage \& Camp: New Designs on the Canadian Landscape

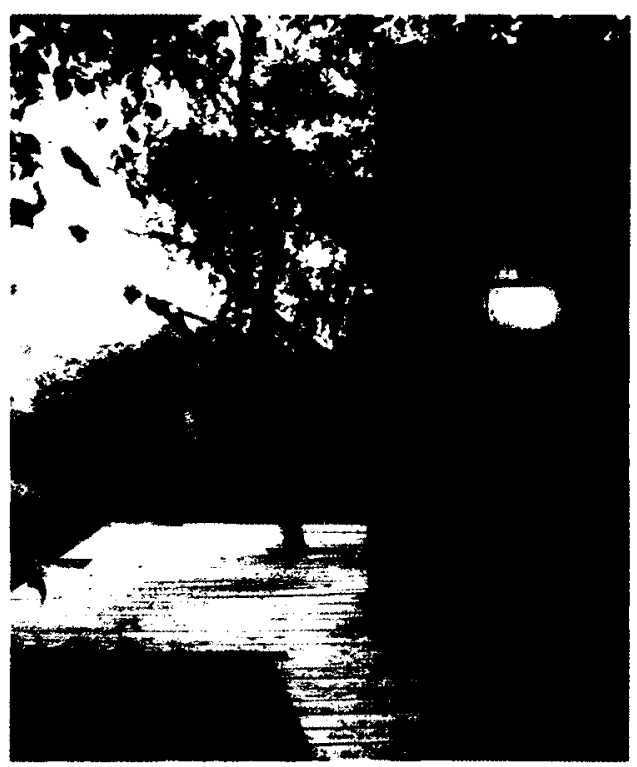

Herbert Enns' Experimental Cabin at Shoal Lake 
helped in the understanding of scale, materiality, and most importantly site engagement and immersion.

The final result is a series of three pavilions to be situated within a specific site of the NCC's Gatineau Park. All of the pavilions use a similar construction method with slight variations in response to context. They are to be immersed into the landscape and respond to their respective themes of trees, water or earth. Overall, the final designs are sensitive to their sites and responsive to their programmatic mandates of research and education. 


\section{Tree}

This first pavilion was developed based on the surrounding trees. It encompasses a small living/working quarters for a researcher connected to a public space. Within the public space there are four programs. These include a small scientific collection and exhibition space to educate visitors on the different species of trees and vegetation within the park, a small information and entrance space for visitors to get their bearings, a small lecture space for displays and hands-on learning, and finally a viewing and rest area overlooking Meech Lake.

This pavilion generates a space that is open in plan enabling the programs to be rearranged depending on event functions. As a result, the pavilion utilizes a post and beam construction, based on the "kit-of-parts," that spans a maximum of $3000 \mathrm{~mm}$ in both vertical and horizontal directions. This grid system is used to organize the space and house the programs.

The researcher's area is comprised of a small sleeping quarters, water closet, cooking space, and work space. The sleeping area is located towards the north end of the site, opposite to the public space. It is isolated from the rest of the dwelling to ensure isolation and privacy from the public areas. A wall and sliding pocket door help achieve this public/private separation. The other three walls utilize the glazed sliding panel system with wood strips layered on them to create a sense of shelter as well as openness. 


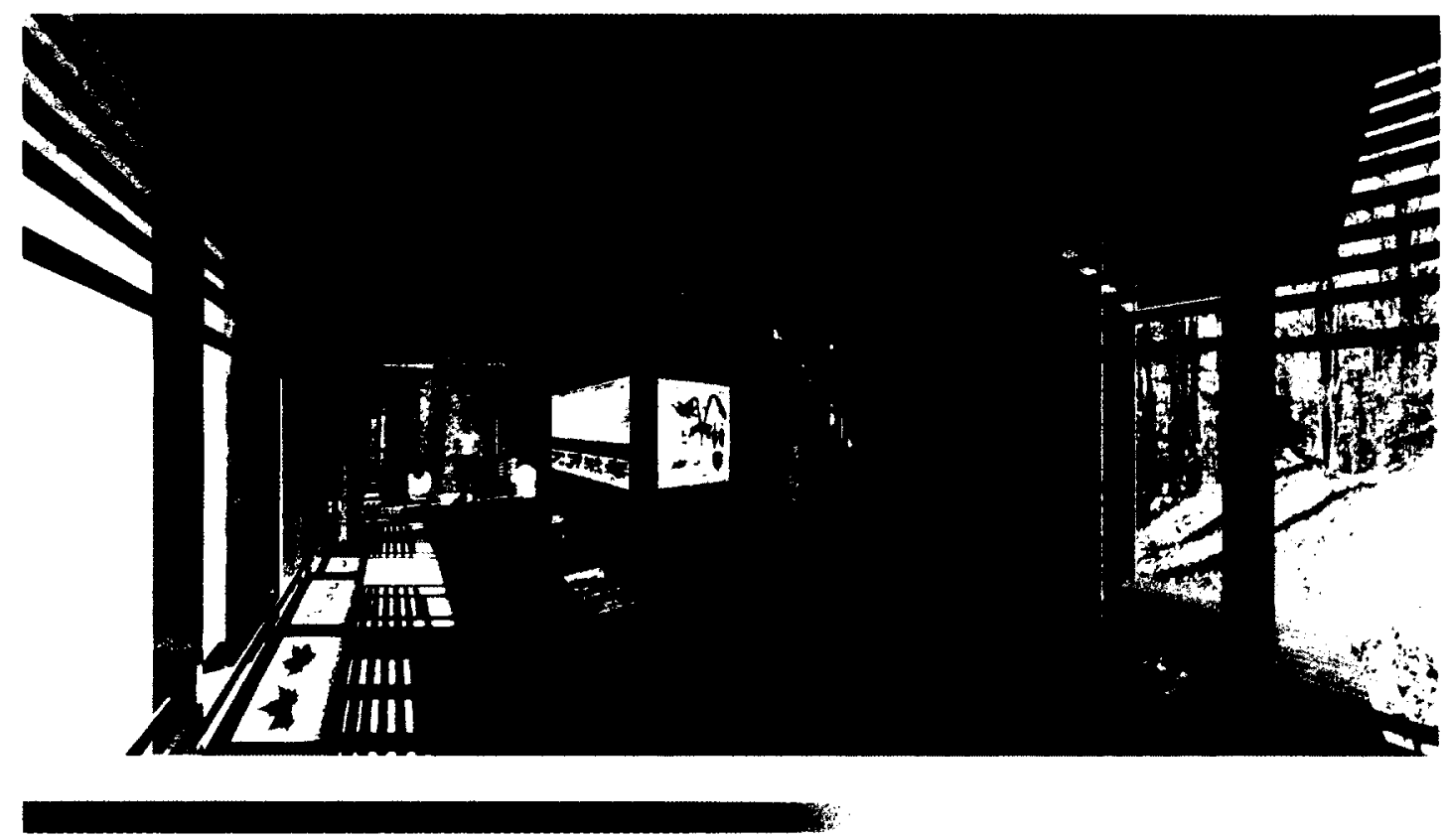

Trees Pavilion Interior Vignette 1 
The water closet is the only area in the pavilion that is completely enclosed by four walls and a roof. Similar to the sleeping quarters, a sliding pocket door ensures a sense of privacy when required.

The cooking and working spaces are connected to the public space. By opening up the space to the public areas it enables a closer interaction between the researchers and the visitors using the pavilion. This space contains a small kitchenette, a table and some chairs to be used by the researchers and visitors alike.

The public space contains the four educational programs relating to indigenous vegetation. The first is a scientific collection and exhibition space comprising of tables housing interactive displays. The general information and entrance space occupies an open area within the centre of the pavilion. Maps of the park help visitors get their bearings within the pavilion and park. Towards the southwest end of the pavilion is the small lecture space. Public speakers use this space to demonstrate and provide hands-on learning experiences about the pavilion's theme and the park. The deck located along the south side of the pavilion is the viewing and rest area that overlooks Meech Lake.

To enter the building, one walks up the path along the southern hillside that links to the deck stairs. The entrance is located along the south façade. However, since the structure is clad almost entirely with sliding panels, fair weather seasonal access is possible from any direction.

The exterior cladding system uses glazed sliding panels that infill the post and beam structure. On the interior surface of these panels are thin strips of wood that help filter the light and generate a sense of screened privacy. When the doors are open, the thin strips of wood overlap, exaggerating this layered effect. Sliding the doors open alludes to the action 
of pushing through a heavily forested area to "blaze a trail" and discover a new space. Furthermore, the composition mimics the trees; the structural posts resembling trunks while the thin wood strips on the glazed panels act as branches.

A corrugated metal roof system is used to shelter the pavilion. Each roof section gently slopes in mimesis with the hilly landscape. Since this pavilion is nestled in the trees, the metal roof will create a symphony when anything falls on it.

Overall, this pavilion enforces the ideas discussed in the thesis. It illustrates that a work of architecture can be achieved in a remote environment with a sensitive interpretation of its relationship to the surrounding landscape. By understanding the complexity of the context, it is possible to achieve a sensitive architectural response. 


\section{Water}

This pavilion borrows a design strategy from the Trees Pavilion while focusing on the park's aquatic systems. It houses a similar research and education program within its public spaces. Yet, it does not provide for private occupancy. The pavilion juts out over Meech Lake along a northsouth axis.

The entrance to the pavilion is located at the north end of the structure along the shores of Meech Lake. Once inside the dwelling, the first program is a general information area describing the water resources within the greater park area. Similar to the Trees Pavilion, this introduces the visitors to the pavilion and to get their bearings. The next space is a small research area. It is comprised of two desks and two chairs to facilitate any experiments or testing related to aquatic systems. Adjacent is a small scientific collection and exhibition space that consists of tables housing thematic displays. Finally, the last space is a rest and viewing area that overlooks Meech Lake and Gatineau Park.

The post and beam structure for this pavilion also spans a $3000 \mathrm{~mm}$ grid. However, since the floor and the roof of this pavilion are both sloped the heights vary slightly from the finished floor level. This structural span and open concept plan enables the pavilion's spaces to be re-organized according to varied events. 


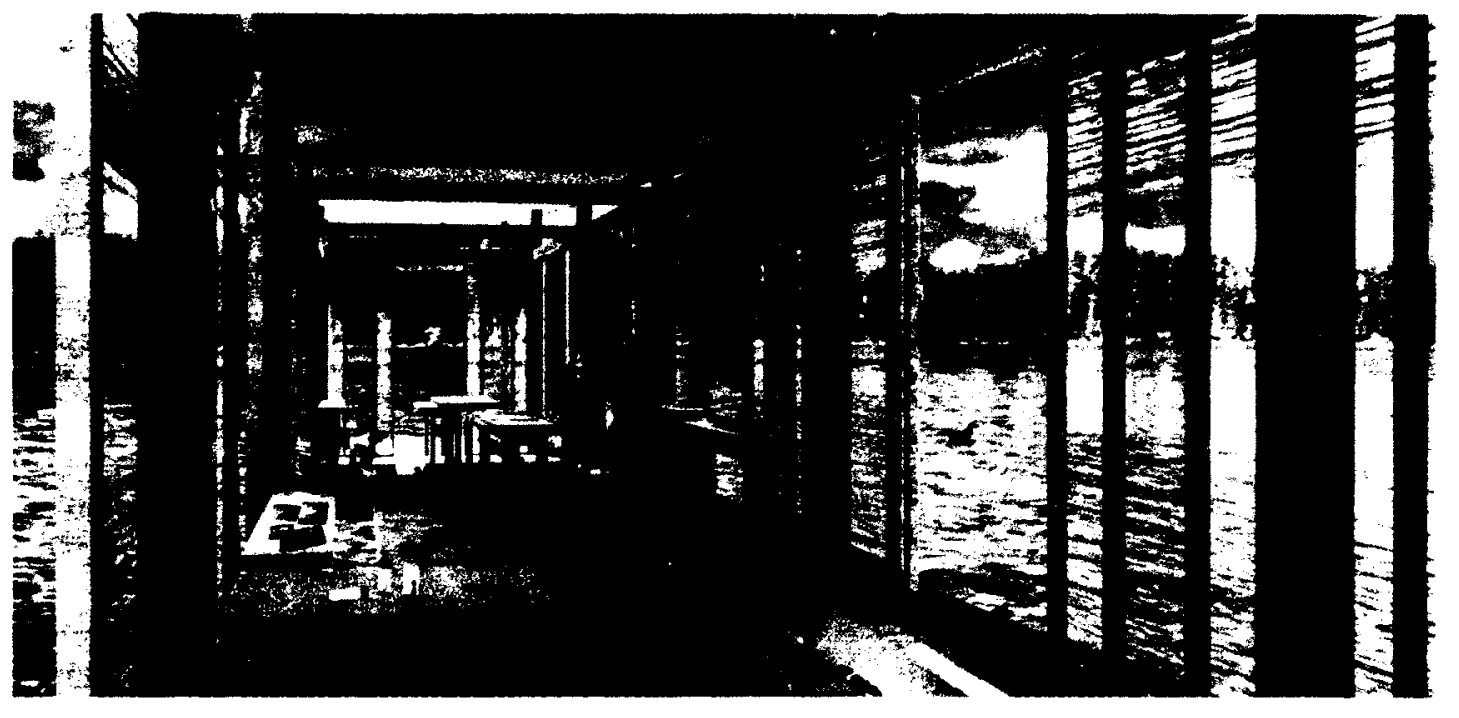

Water Pavilion Interior Vignette 1 
Similarly to the trees pavilion, sliding glazed panels span between the structural posts. However, the panels use cast glass that mimic the water's rhythm and reflective surface. Thus, when an interaction with the panels occurs, the overlapping of the cast glass panels generates a wave motion. As a result, a sense of movement is created in the pavilion in concert with the adjacent landscape.

The floor is gently sloped, as is the roof, to mimic the landscape's planes and the overlapping motion of the water. The sloped floor also contains openings that afford views into the water below and allows precipitation to pass through the building.

The roof is clad in a corrugated metal roofing system similar to the Trees Pavilion. In addition, holes are perforating the roof in select areas, allowing water to pass through the building. This helps to reinforce the relationship between the building and water above and below. Openings in the floor accommodate the water's journey through the building.

This pavilion incorporates water in its design development by using this element as a physical and conceptual influence. It also emphasizes the ability to generate micro architecture in a remote environment. By generating another pavilion that focuses on a different aspect of the site, it further solidifies the ability to design a sensitive work of architecture that responds to a site's context and complexity utilizing a "kit-of-parts." 


\section{Earth}

This final pavilion is designed using a similar strategy and system as the previous two studies. In this instance, the central element and generator is earth. This space accommodates the same program as the Trees Pavilion, comprised of both public and private spaces supporting park visitors and researchers alike.

The private space is comprised of the researcher's personal quarters and includes a small sleeping area, a water closet, cooking space and living space. The cooking and living spaces are connected to the public space with a glazed sliding panel system. The sleeping quarters and water closet follow the same strategy as the Trees Pavilion. The water closet is completely isolated whereas the sleeping space is partially closed off.

Within the public space there is a lecture and viewing space that connects to the private research area. Next to this space is a general information area where visitors enter the building and get their bearing within the park. This space houses basic information about the park and the pavilion's mandate. The last space in the pavilion frames a scientific collection and exhibition. It is comprised of some tables housing multimedia displays as well as physical samples of soils and minerals found in the area that visitors can interact with.

The Earth Pavilion, in contrast to the previous two iterations defined by a $3000 \mathrm{~mm}$ grid, utilizes a structural grid raised to $2100 \mathrm{~mm}$ from finished 


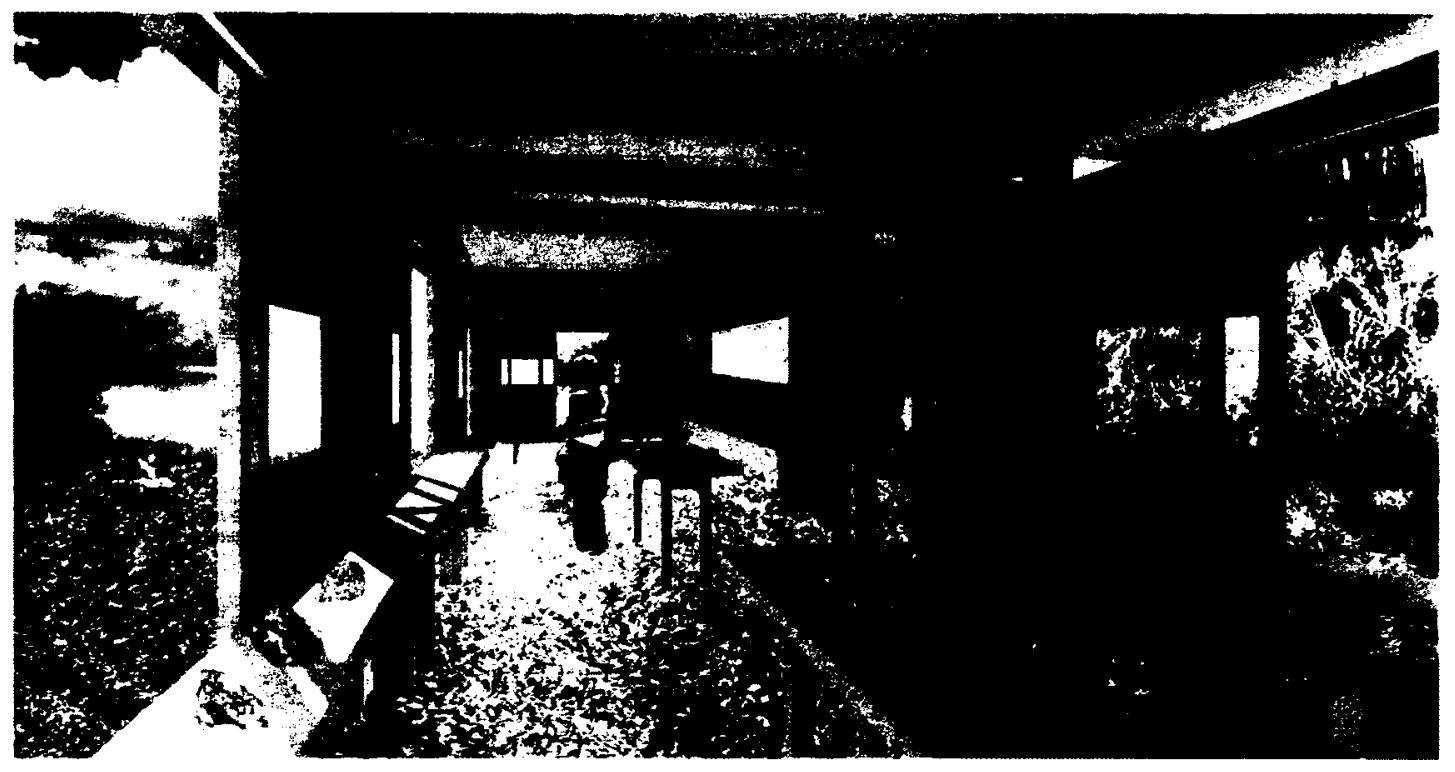

Earth Pavilion Interior Vignette 1 
floor. This emphasizes a "closeness" to the ground by creating a sense of compression within the pavilion.

The exterior cladding uses a similar system to the other two pavilions. In this case though, it uses earth and small vegetation components on the exterior face of the glazed panels. This helps to immerse the structure into the landscape. Inside the pavilion, the effect is a much darker, cave like, experience. It is only when the glazed panels are opened that more light and air sweep through the building and the weight, and darkness, are lifted.

Instead of constructing a floor throughout the entire structure, the public spaces are set on the existing ground. It is only in the private space, which has been slightly elevated, that a conventional floor is constructed. This is to ensure comfort within the private space in contrast to a closer interaction with the ground in the public space.

The roof system uses stone slabs to protect the interior from seasonal elements. The roof slopes are minimal and mimetic of tectonic plates that make the Earth's surface while emphasizing an experience of dwelling in a cave.

This final pavilion further reinforces an architectural strategy sensitive to its site context. All three separate pavilions, located in the same region but designed with different thematic generators illustrate the importance of context in the design process culminating in a site-sensitive architecture. 


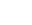




\section{Pavilion Documentation}

The real vovage of discovery consists not in seeking new landscapes, but in having new eyes

- Marcel Proust

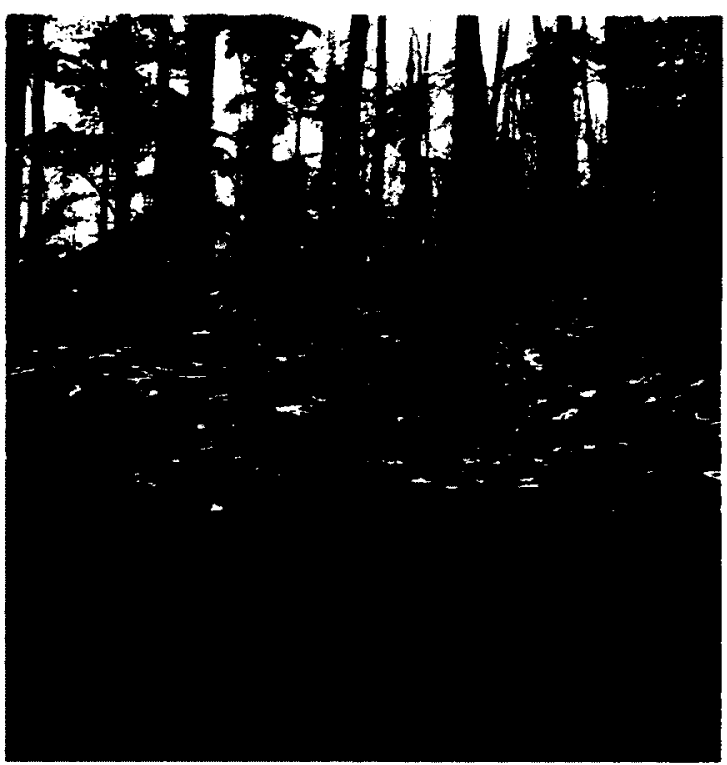




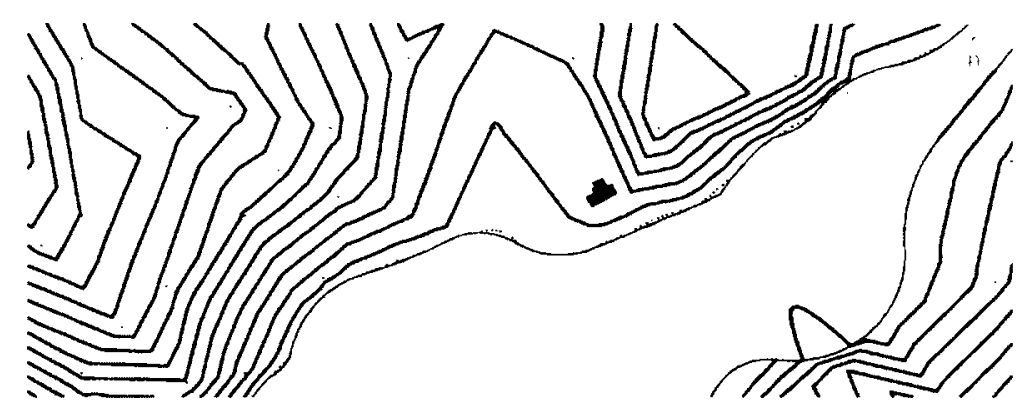

Tres Pathm

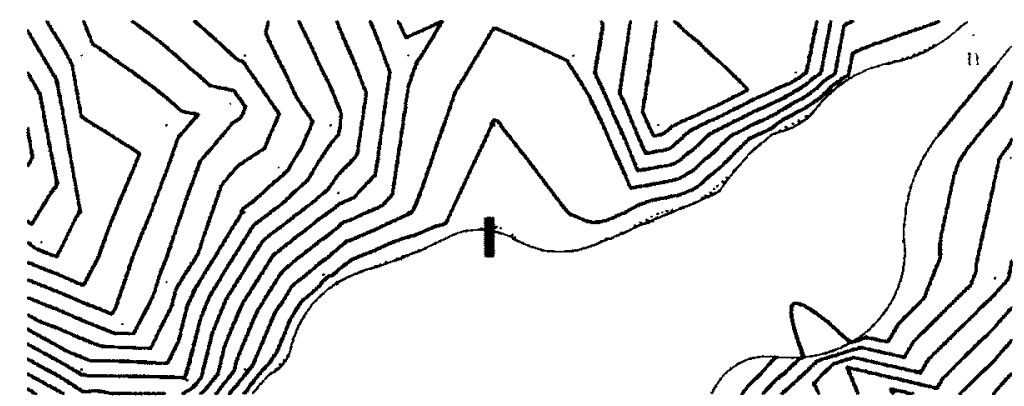

Water Pattim

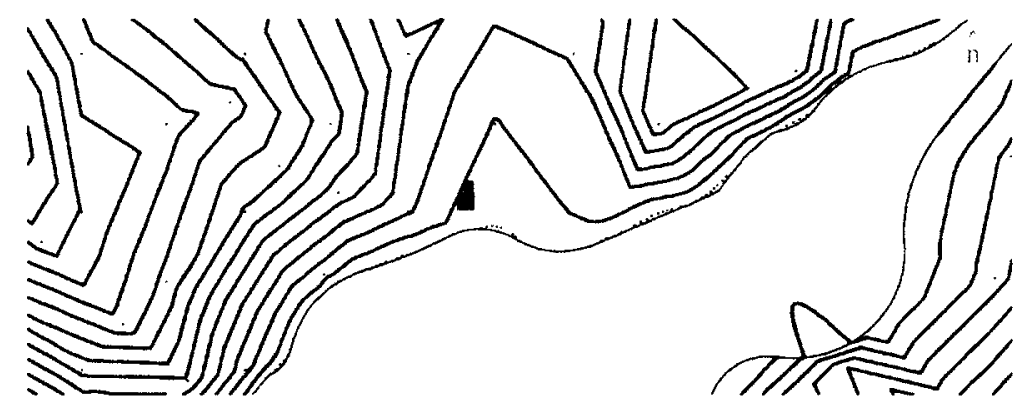

Eartla Patilum

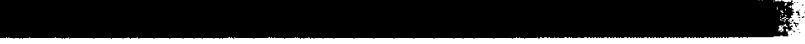

Site Maps 


\section{Trees Pavilion}

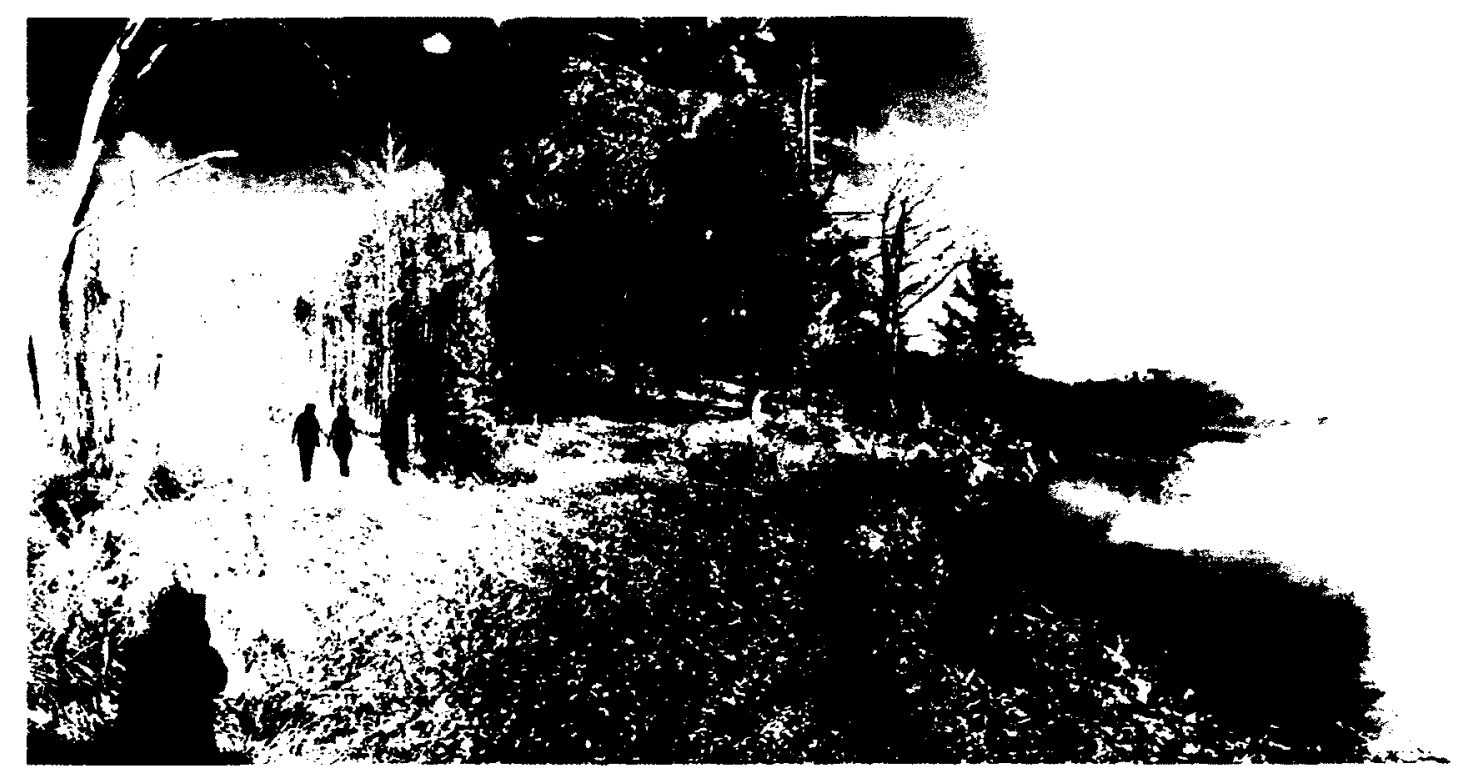

Trees Pavilion Exterior Vignette 1 


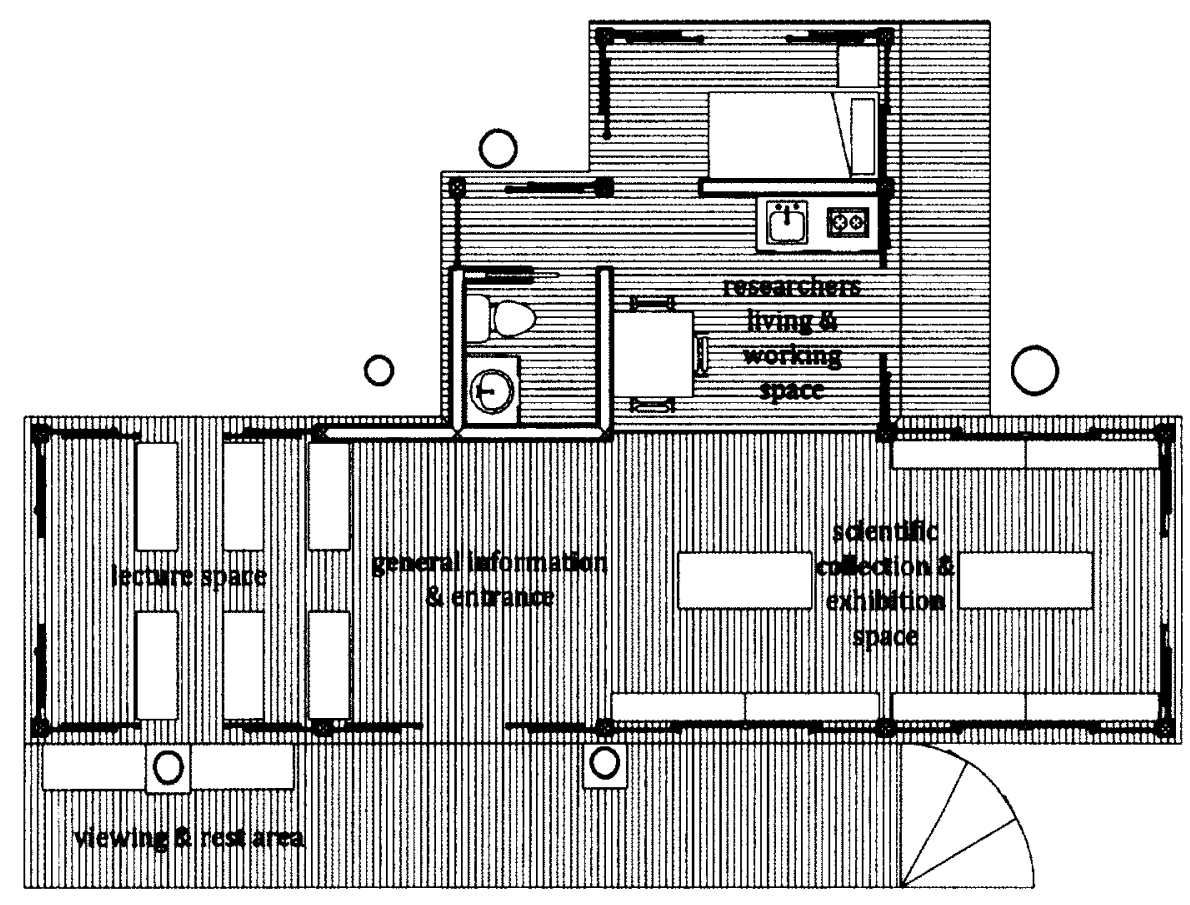

Trees Pavilion Plan 

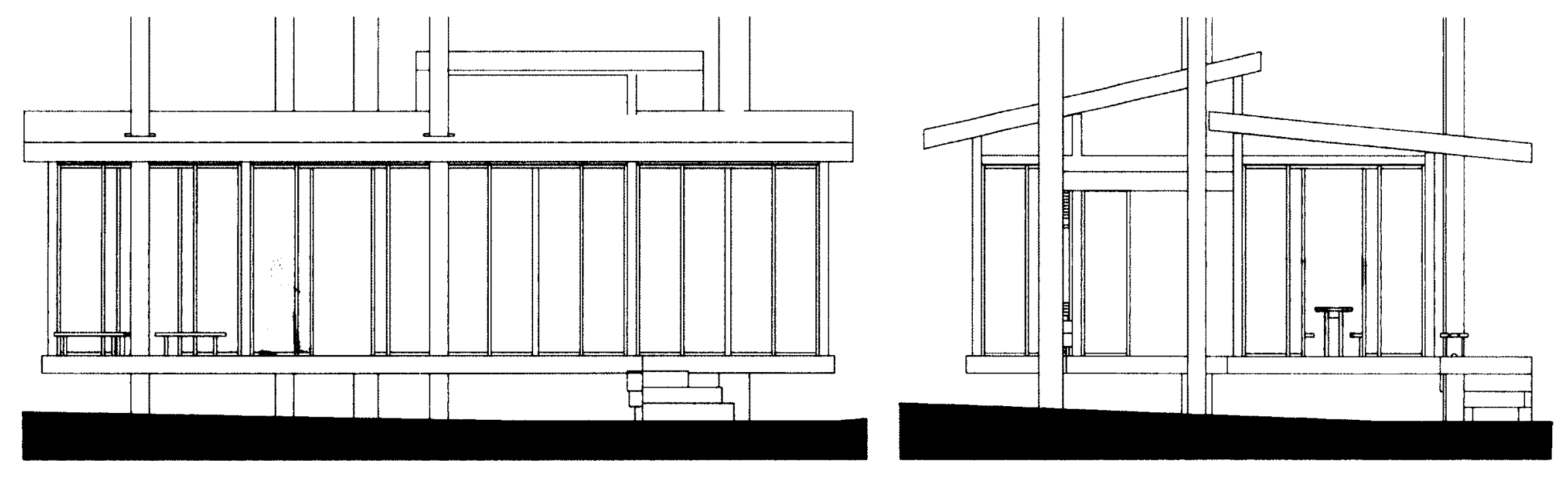

Trees Pavilion South Elevation

Trees Pavilion West Elevation 

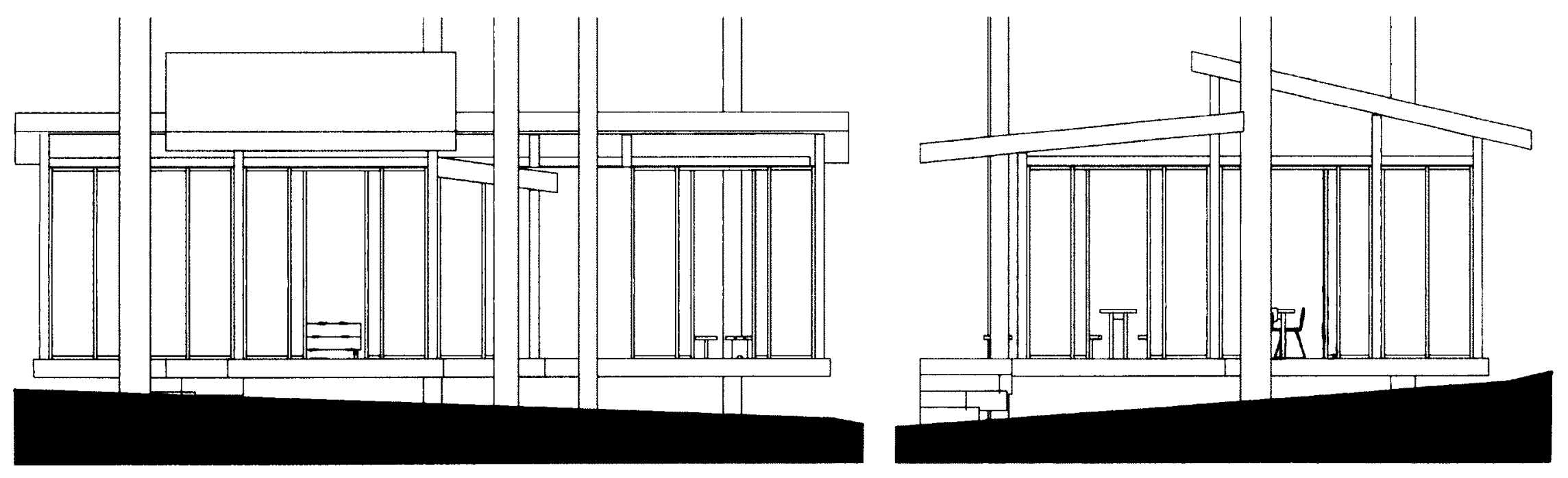


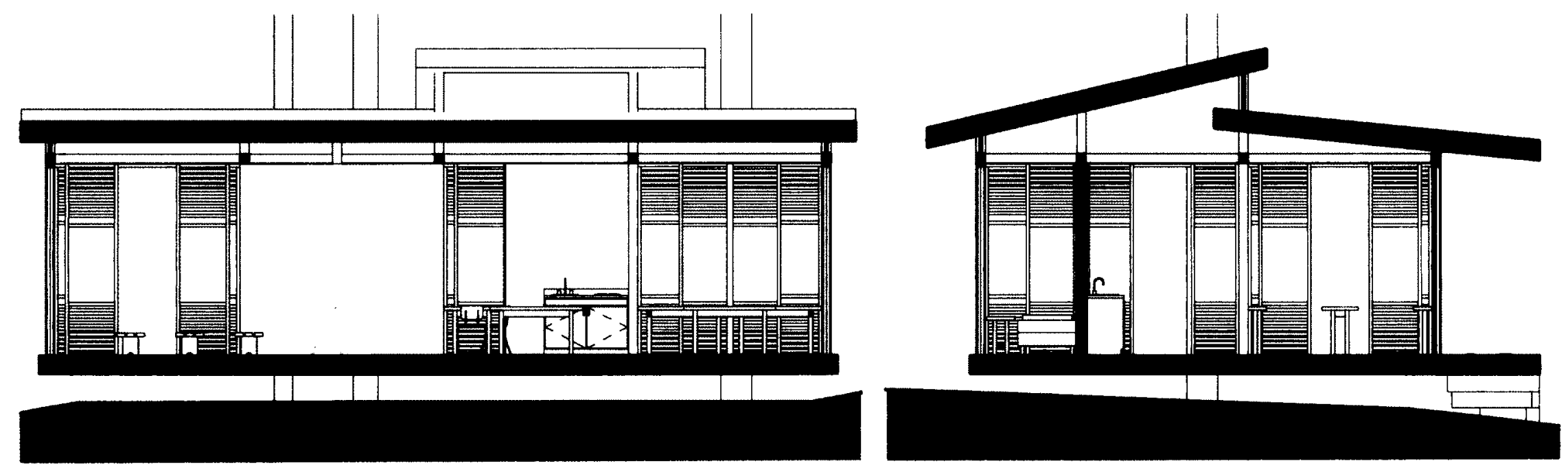




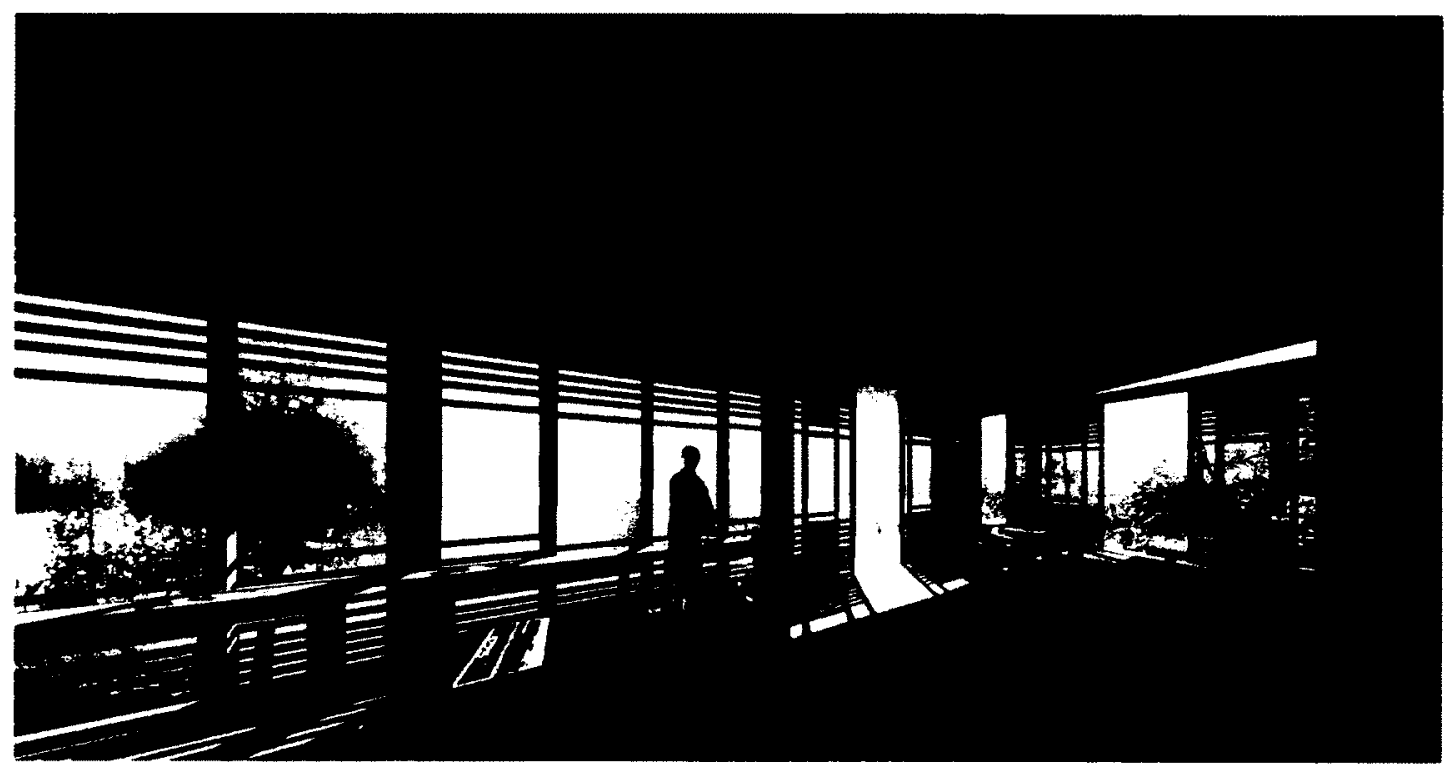

Trees Pavilion Interior Vignette 2

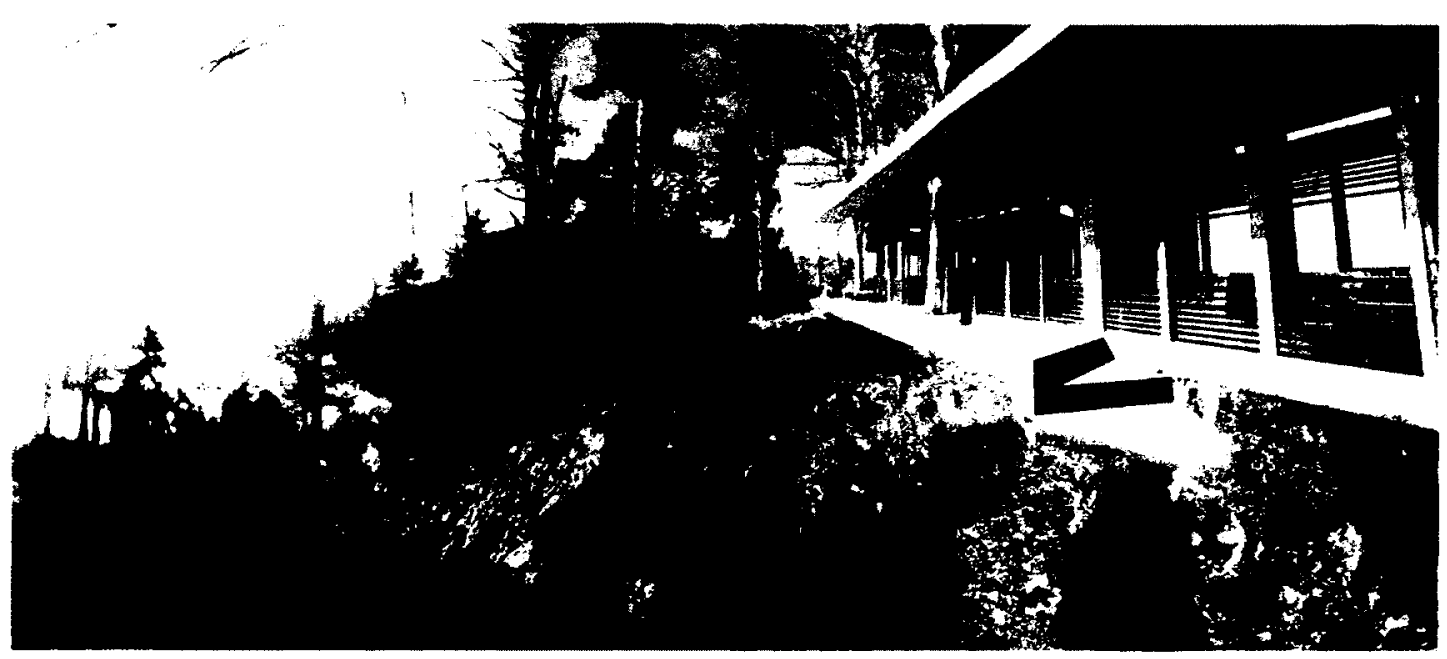

Trees Pavilion Exterior Vignette 2 


\section{Water Pavilion}

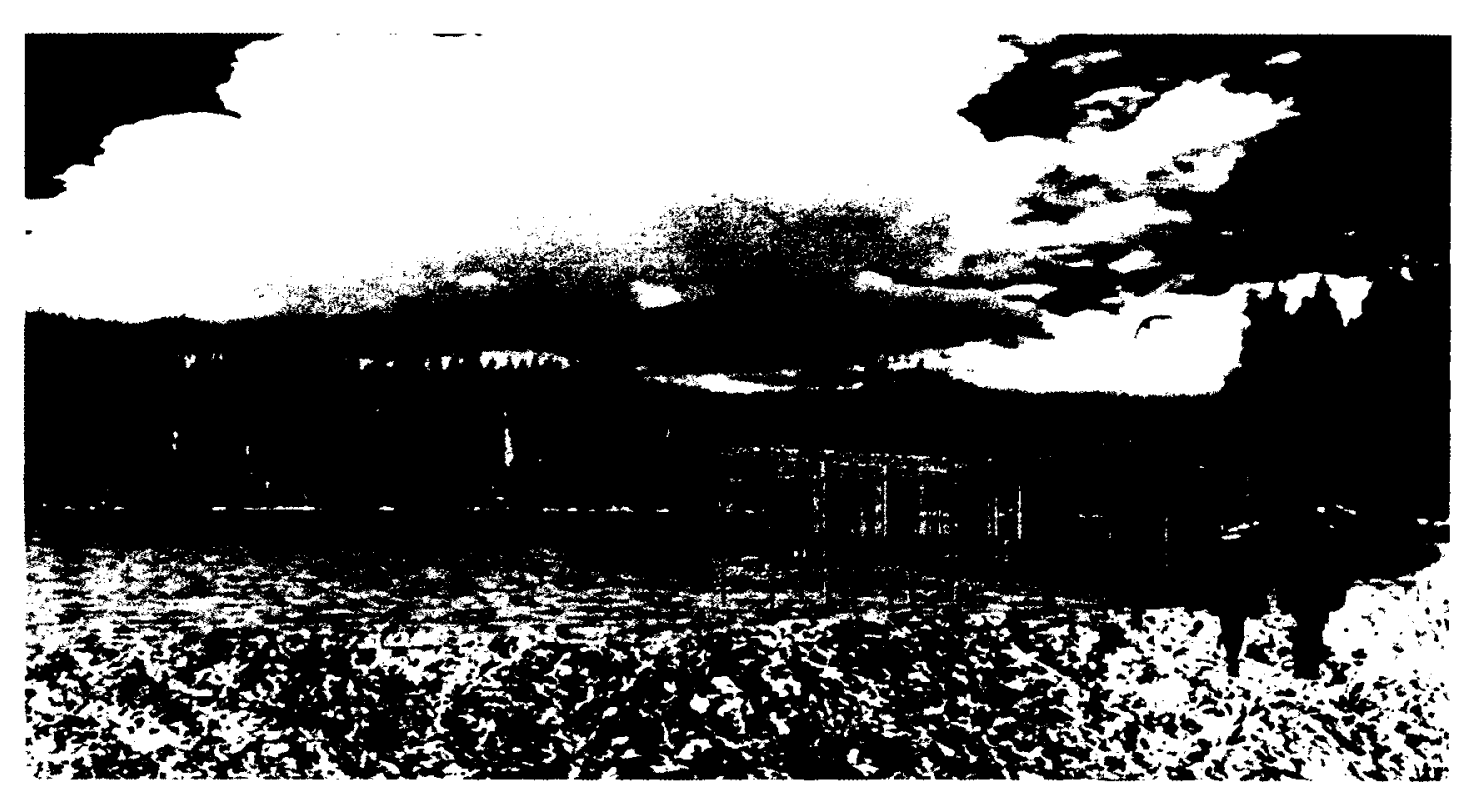

Water Pavilion Exterior Vignette 1 


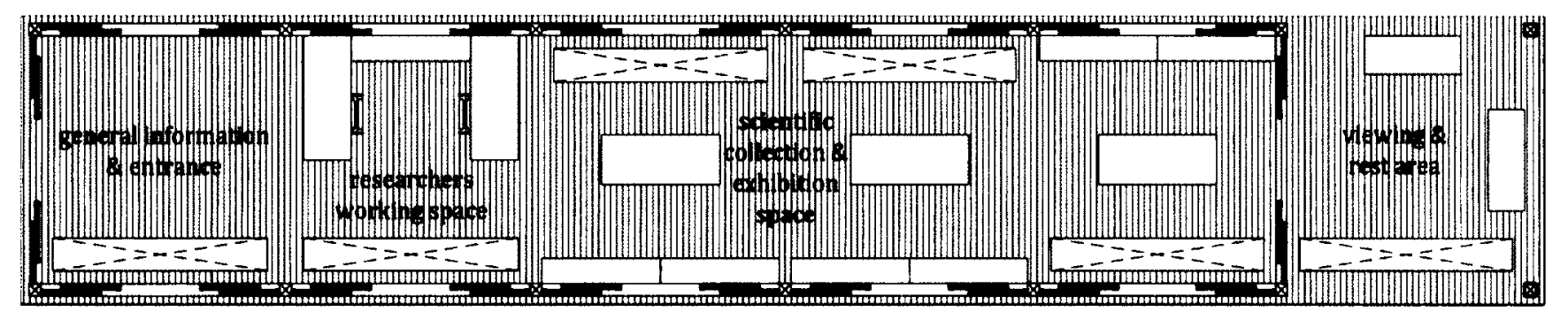

$n+$

Water Pavilion Plan 

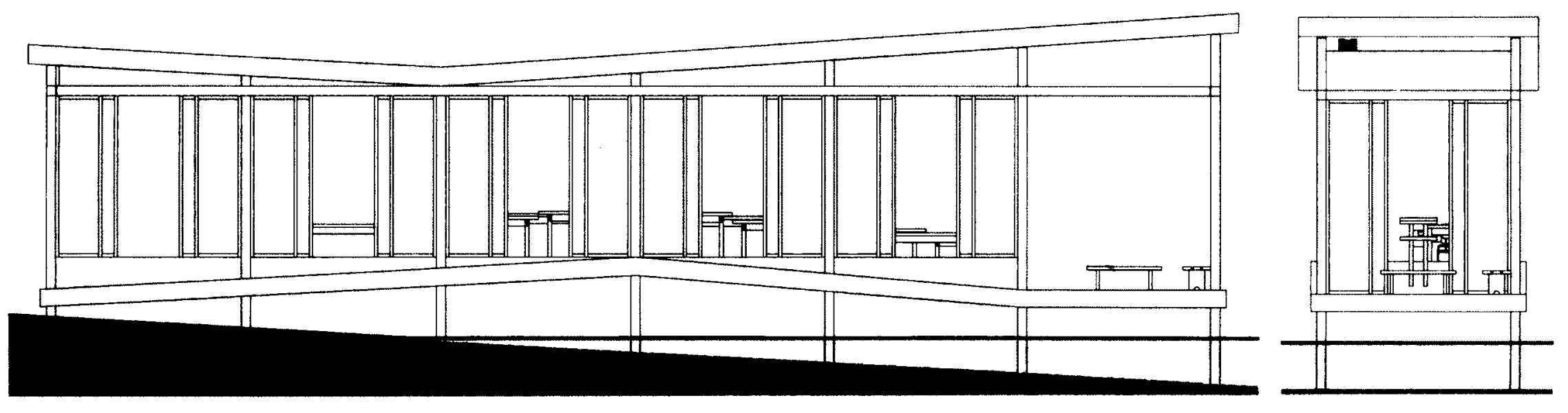

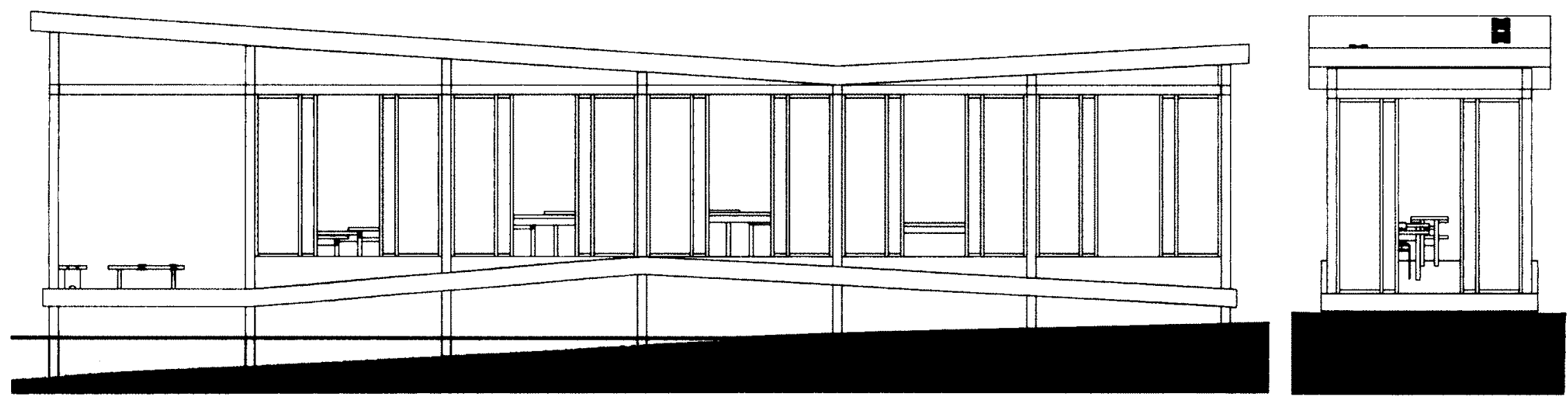

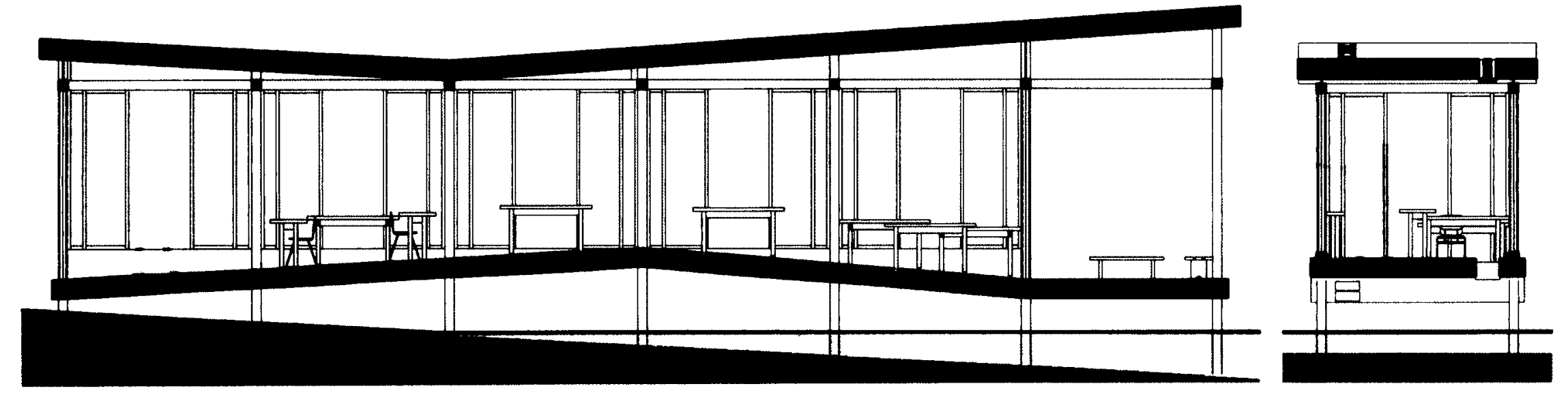


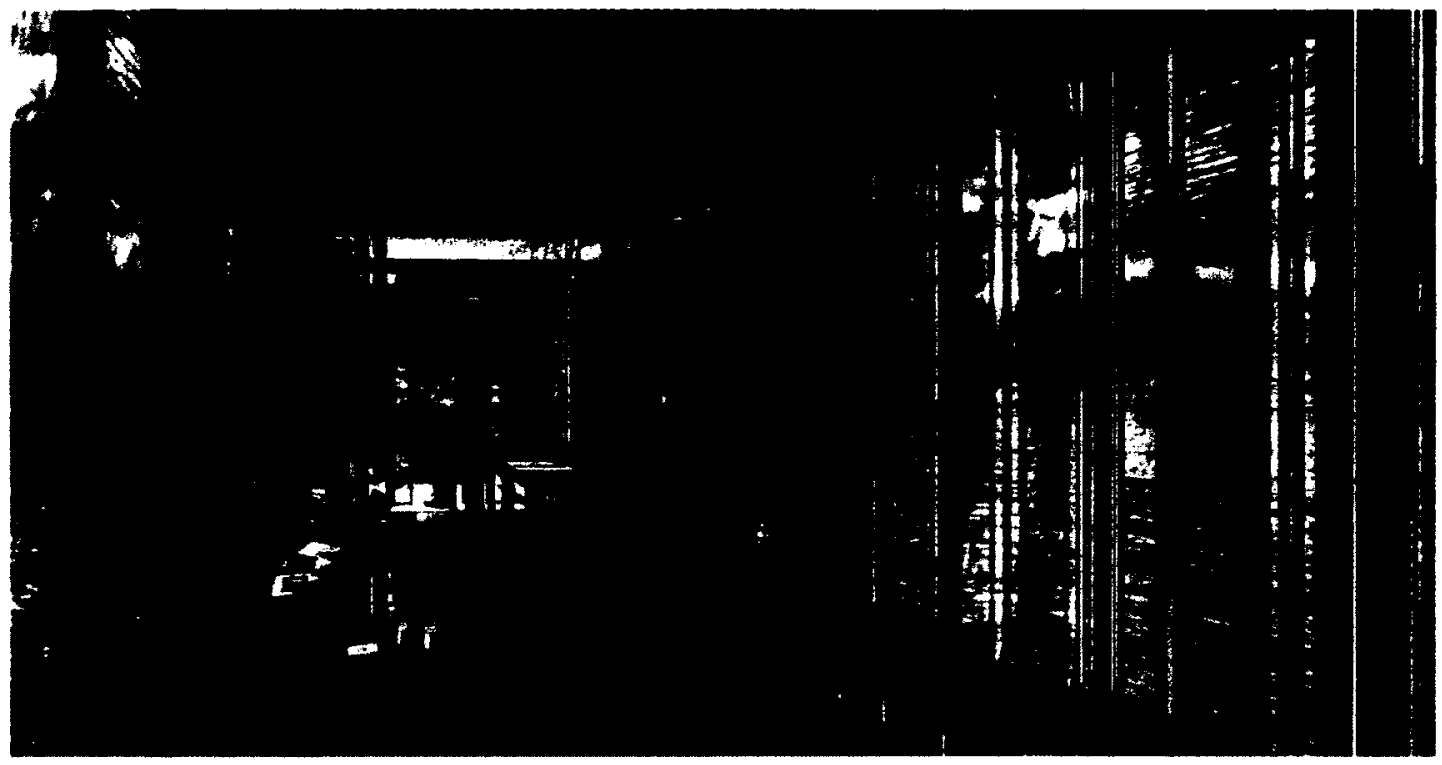

Water Pavilion Interior Vignette 2

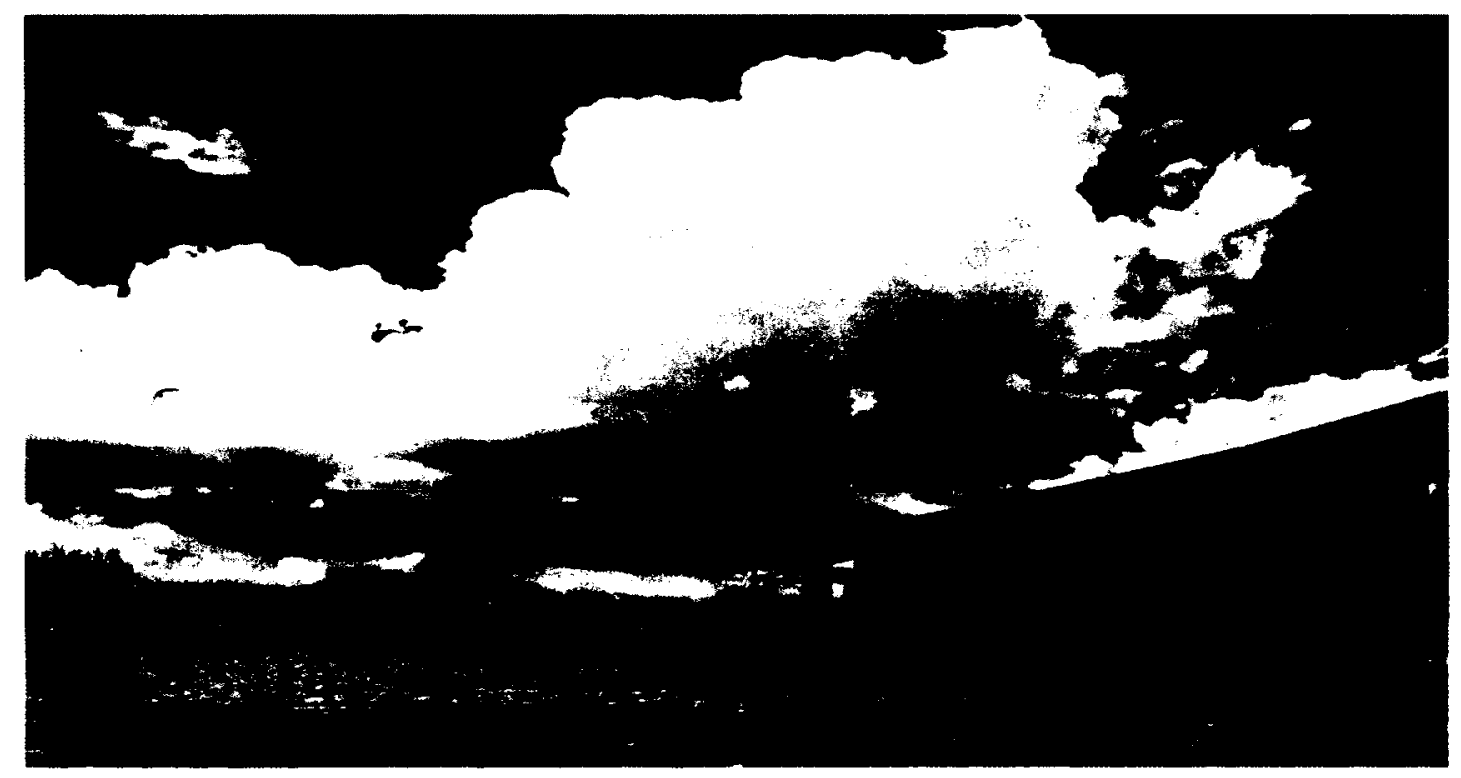

Water Pavilion Exterior Vignette 2 


\section{Earth Pavilion}

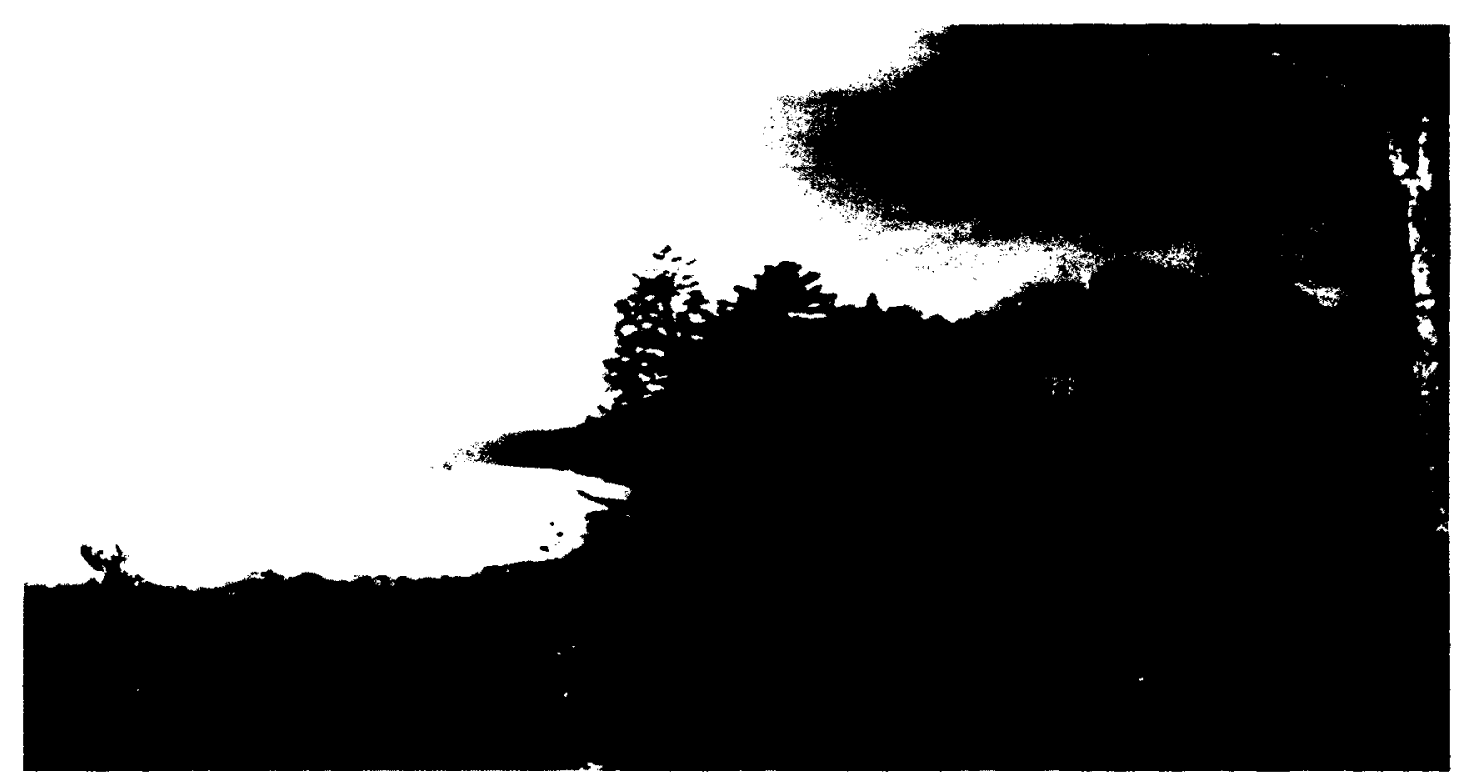

Earth Pavilion Exterior Vignette 1 


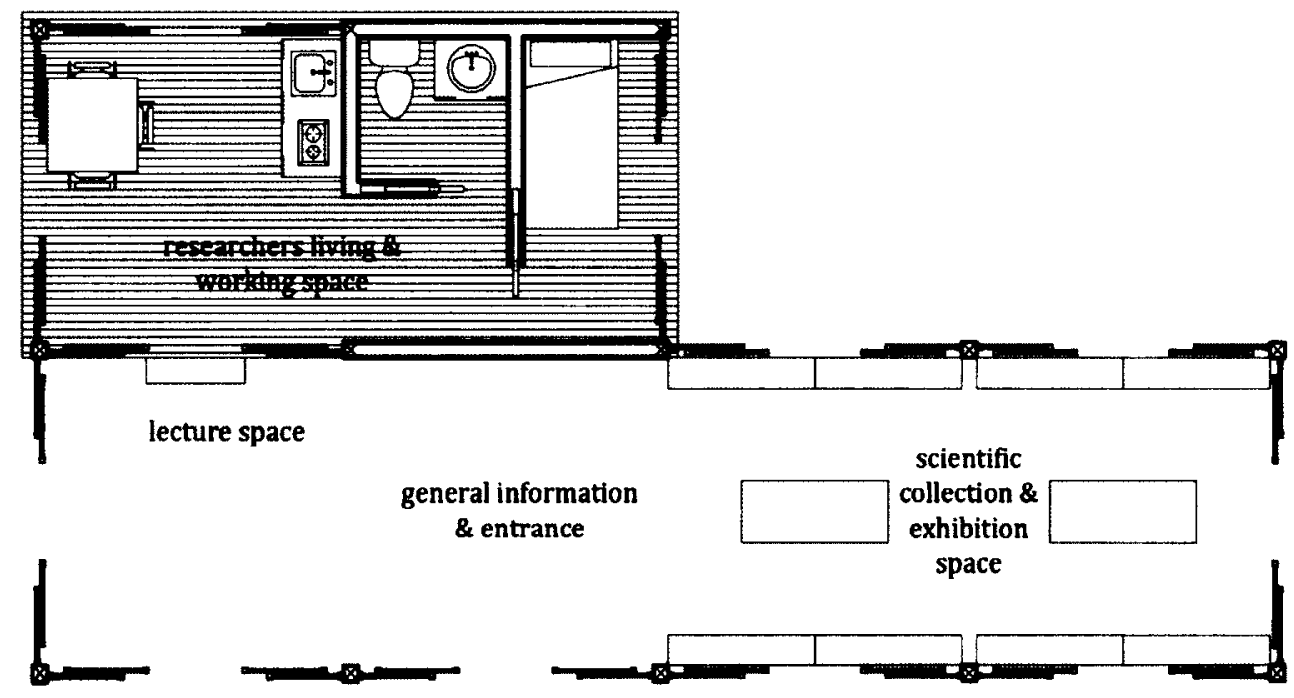

$+n$

Earth Pavilion Plan 

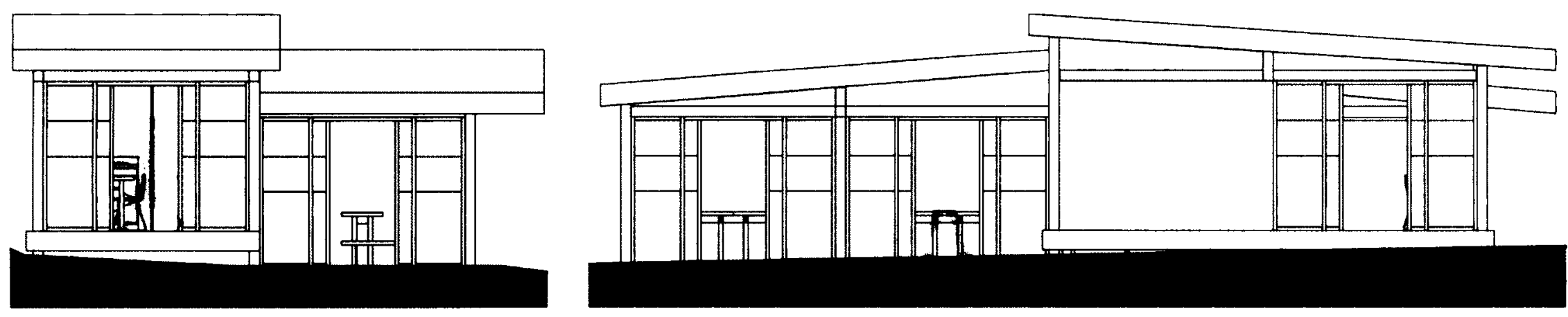

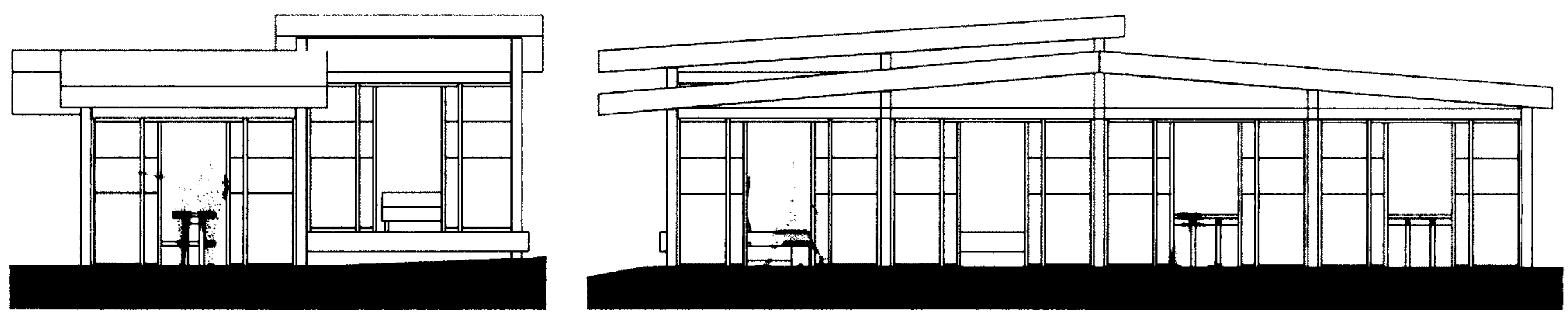


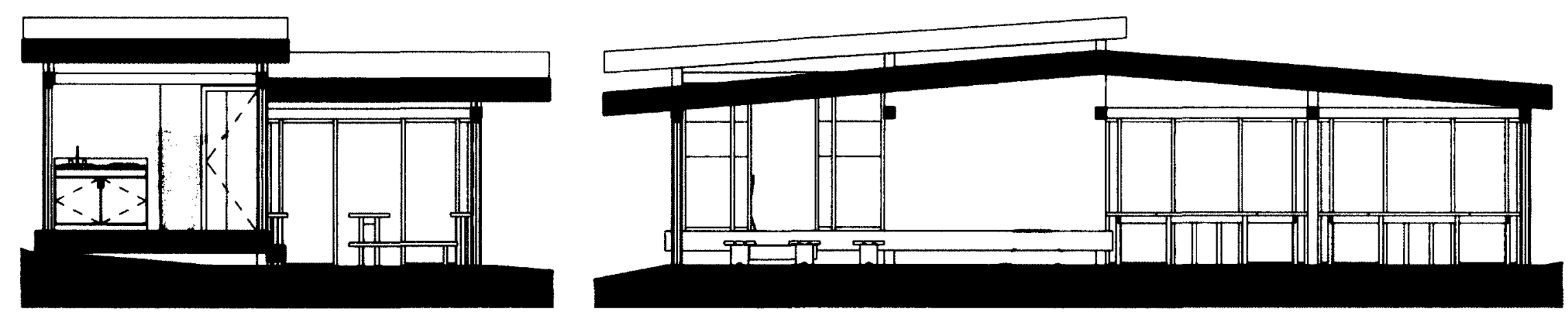




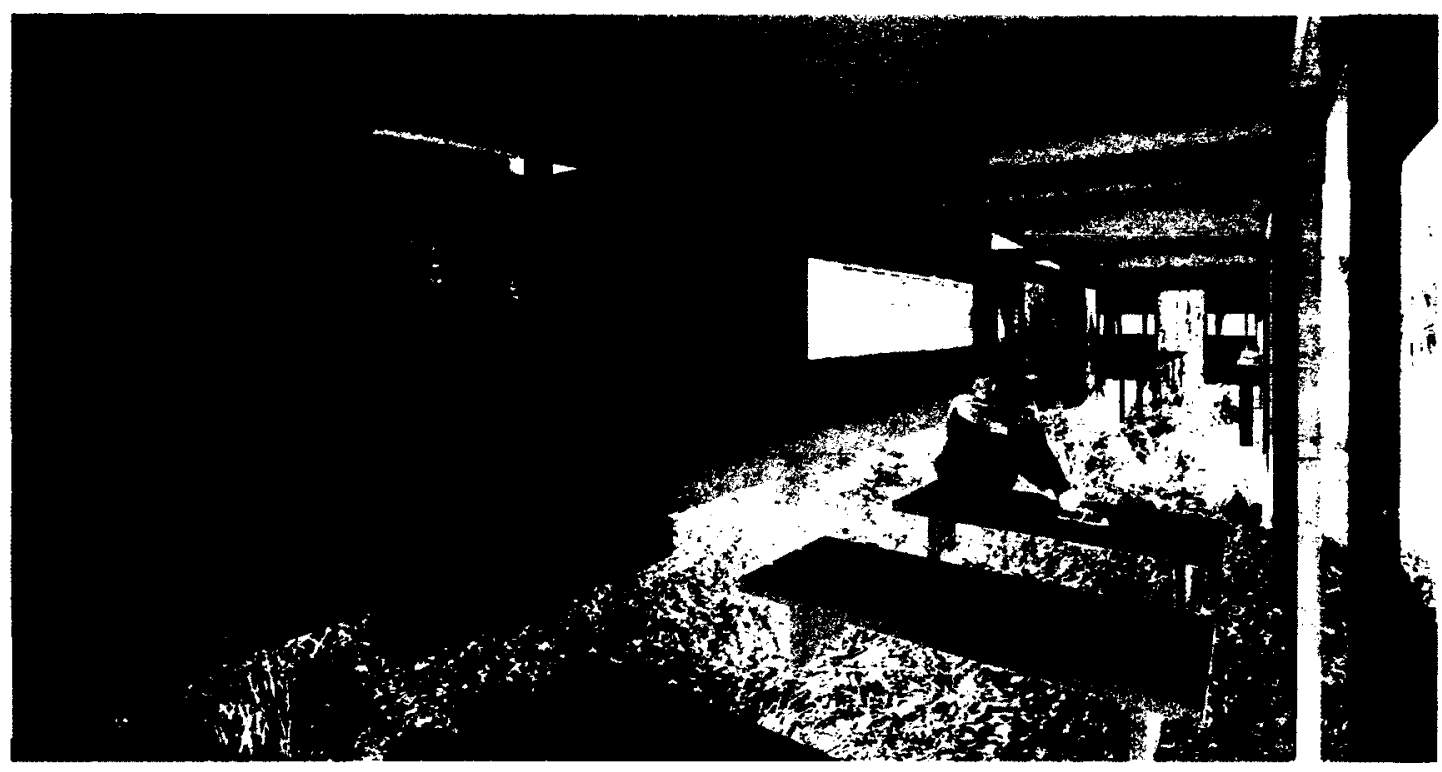

Earth Pavilion Interior Vignette 2

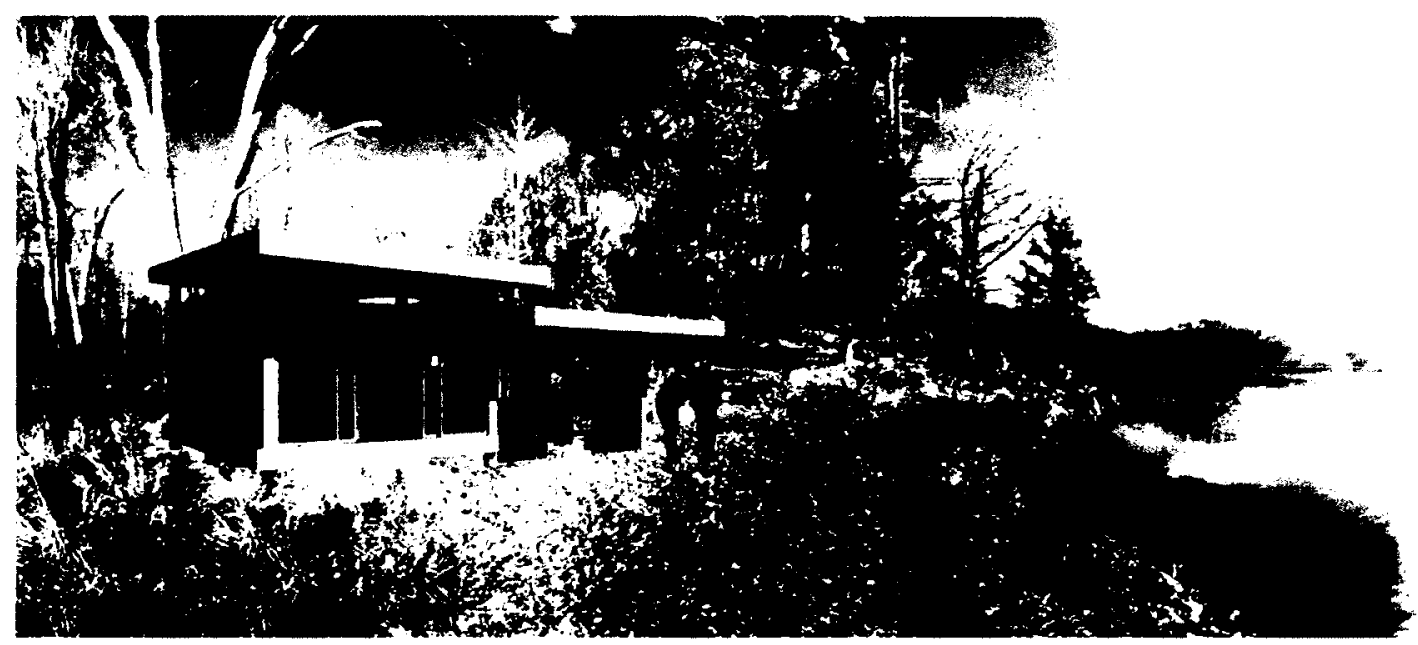

Earth Pavilion Exterior Vignette 2 



\section{Post Script}

The main trend of our time is toward bigness. The general belief seems to be that things become better as they become bigger. Everyone is greatly impressed by bigness. Only a few are aware of the dangers of substituting quantity for quality, $a$ value only human beings can create.

- Ludwig Hilberseimer ${ }^{54}$

Hilberseimer's quote sums up quite eloquently the purpose of this thesis. As a society, there is more focus and recognition for works of macro architecture that has resulted in a forgotten micro architecture. The micro scale seems less important in a world consumed by larger than life spectacles where it doesn't receive as much recognition, or appreciation, as it could.

Focusing on micro architecture generates ideas that can be explored before being considered for larger projects. For example, the scales of many micro architecture projects are similar to floor plans of small apartments and office spaces. It is through the assimilation of these smaller entities that larger constructs, such as towers or multi-purpose buildings, are realized. Thus the bases for many larger scale architectural programs are derived from the micro. Therefore, if the micro scale isn't understood or appreciated for its importance on progressing architecture, it makes it difficult to progress from the micro to the macro. As a result, the development of micro architecture informs the macro scale that occupies our world.

54 Ludwig Hilberseimer, 'Bigness and its Effects on Life', 1944. 



\section{Works Cited}

Bachelard, Gaston. The Poetics of Space. Beacon Press: Boston, 1969.

Beaver Brook. "Cabin Porn: Inspiration for your Quiet Place Somewhere."

(Fall 2012) 4 Sep. 2012. <http://freecabinporn.com/>.

Bishop, Deborah. "Barely There." (Jul/Aug 06) 21 Dec. 2012. <http://www. dwell.com/articles/barely-there.html .

Calvino, Italo. Cosmiconics. Trans. William Weaver. Cape: London, 1969.

Calvino, Italo. The Baron in the Trees. Trans. Archibald Colquhoun. Collins: London, 1959.

Canadian Parks and Wilderness Society. Gatineau Park: A Threatened Treasure. 2008.

Carleton University Library. "GIS: What is GIS? (PDF)" 18 Feb. 2013. <http:// www.library.carleton.ca/help/gis-what-gis>.

Carmichael, Franklin. Bay of Islands. 1931. Painting.

Casson, A.J. Pike Lake. 1929. Painting.

Deleuze, Gilles. A Thousand Plateaus: Capitalism and Schizophrenia. University of Minnesota Press: Minneapolis, 1987.

Einstein, Albert. "The World As I See It," Forum and Century, 1931.

Elliot Brood. Days Into Years. Paper Bag Records/Fontana North, 2011.

Frascari, Marco. "A New Corporeality of Architecture." Journal of Architectural Education, Vol. 40, No. 2, Jubilee Issue (Winter, 1987).

Gould, Glenn. Bach: The Goldberg Variations. Sony BMG Music Entertainment, 1982, 1984.

Harris, Lawren. Lake and Mountains. 1928. Painting.

Heidegger, Martin. What is a thing? Tans. W. B. Barton, Jr., and Vera Deutsch. H. Regnery Co.: Chicago, 1967.

Hilberseimer, Ludwig, 'Bigness and its Effects on Life', 1944. 
Holl, Steven, Juhani Pallasmaa and Alberto Pérez-Gómez. Questions of Perspective: Phenomenology of Architecture. a+u Publishing Co., Ltd.: San Francisco, CA., 2006.

Horden, Richard. Micro Architecture. Thames \& Hudson Ltd.: London, 2008.

Into The Wild. Dir. Sean Penn. Perf. Emile Hirsch, Vince Vaughn and Catherine Keener. Paramount Vantage, 2007. Film.

Kerouac, Jack. On the Road: The Original Scroll. Viking: New York, 2007.

Kronenberg, Robert, ed. Transportable Environments 3: Theory, Context, Design and Technology. Taylor \& Francis: London, New York, 2006.

Larousse. "Pavillon." (2008) 21 Dec. 2012. <http://www.larousse.com/en/ dictionaries/french/pavillon/58800>.

Macdonald, Christopher. Cabin, Cottage \& Camp: New Designs on the Canadian Landscape. Bluemprint: Italy, 2005.

Manfred Felsch. "Cornelia Konrads." (2013) 12 Oct. 2012. <http://www. cokonrads.de>.

Massey, Doreen. For Space. SAGE: Thousand Oaks, Calif., 2005.

Merleau-Ponty, Maurice. Phenomenology of Perception. Routledge: New York, 2012.

National Capital Commission "About Gatineau Park" (2012) 15 Dec. 2012. <http://www.canadascapital.gc.ca/places-to-visit/gatineau-park/ about-gatineau-park>.

National Capital Commission "Eardley Escarpment" (2012) 23 Feb. 2013. <http://www.canadascapital.gc.ca/places-to-visit/gatineau-park/ eardley-escarpment>.

National Capital Commission "Heritage and Culture in Gatineau Park" (2012) 20 Dec. 2012 . <http://www.canadascapital.gc.ca/places-to-visit/ gatineau-park/conservation-gatineau-park $>$.

Natural Resources Canada. “Changing Landscape”. (2008) 23 Mar. 2013. <http://www.nrcan.gc.ca/earth-sciences/products-services/ mapping-product/geoscape/ottawa/6275>.

Natural Resources Canada. "Different Rocks." (2008) 23 Mar. 2013. <http:// www.nrcan.gc.ca/earth-sciences/products-services/mappingproduct/geoscape/ottawa/5989>.

Note by Note: The Making of Steinway L1037. Dir. Ben Niles. Perf. PierreLaurent Aimard, Harry Connick Jr. and Hélène Grimaud. Plow Productions, 2007. Film. 
Northern Tool + Equipment. "Mr. Heater Tank-Top Propane Heater." 1 May. 2013. <http://www.northerntool.com/shop/tools/ product_200485295_200485295>.

Oxford University Press. "Pavilion." (2012) 21 Dec. 2012. <http:// oxforddictionaries.com/definition/english/pavilion?q=pavilion>.

Pallasmaa, Juhani. Eyes of the Skin: Architecture and the Senses. Wiley Academy: Chichester; John Wiley \& Sons Ltd.: Hoboken, NJ , 2005.

Pallasmaa, Juhani. The Thinking Hand: Existential and Embodied Wisdom in Architecture. John Wiley \& Sons Ltd.: Chichester, United Kingdom, 2009.

Patrick Watson. Close to Paradise. Secret City Records, 2006.

Pérez-Gómez, Alberto. Built Upon Love: Architectural Longing after Ethics and Aesthetics. MIT Press: Cambridge, Mass., 2006.

River and Tides: Andy Goldsworthy Working with Time. Dir. Thomas Riedelsheimer. Perf. Andy Goldsworthy. Mediopolis Film- und Fernsehproduktion, 2001. Film.

Rochon, Lisa. Up North: Where Canada's Architecture meets the Land. Key Porter Books: Toronto, 2005.

Sherpa. "Sherpa." 1 May. 2013. <http://www.sherpa-verbinder.com/en/>.

Smith, David Woodruff. "Phenomenology." The Stanford Encyclopedia of Philosophy. (Fall 2011 Edition) 4 May. 3013. <http://plato.stanford. edu/archives/fall2011/entries/phenomenology/>.

Sound City. Dir. David Grohl. Perf. Trent Reznor, Tom Petty and Mick Fleetwood. Therapy Content, 2013. Film.

Sun-Mar. "How Composting Works." 1 May. 2013. <http://www.sun-mar.com/ tech_how.html>.

“The Smokehouse." Perf. Rohan Anderson. (Sep. 2012) 14 Sept. 2012. <http://www.smithjournal.com.au/video/thesmokehouse>.

Thoreau, Henry David. The Variorum Walden. New York: Washington Square Press, 1967.

Toolik Field Station. "General Use Eqipment." (2012) 23 Mar. 2013. <http:// toolik.alaska.edu/edc/equipment/index.php>.

Varley, Fred. Stormy Weather, Georgian Bay. 1921. Painting.

White, E.B. Poems and Sketches of E.B. White. Harper \& Row: New York, 1981. 


\section{Image Sources}

\section{Introduction}

By Author. Gatineau Park Intervention. 2012.

Gill, Bryan Nash. “Cedar Burl.” (2011) 17 Mar. 2013. <http://www. bryannashgill.com/gallery.html\&gid=6\&gpn $=2>$.

\section{Points of Departure}

White, E.B. One Man's Meat. Harper and Brothers: New York, 1994.

\section{Site Context}

By Author. Site Fisheye 1. 2012.

By Author. Hand Drawn Tree Site Map. 2012.

By Author. Site Aerials. 2013.

By Author. Gatineau Park Sun Paths: Summer Solstice, Fall/Spring Equinox, and Winter Solstice. 2013.

By Author. Site Panorama 1. 2012.

National Capital Commission. The "Carbide" Wilson Ruins. (2012) 20 Dec. 2012. <http://www.canadascapital.gc.ca/places-to-visit/ gatineau-park/conservation-gatineau-park>.

By Author. Gatineau Park Nudism Prohibited. 2012.

By Author. Pavilion vs. Trees. 2013.

By Author. Pavilion vs. Water. 2013.

By Author. Pavilion vs. Rock Face. 2013.

Design Boom. "Iori Tomita: New Wold Transparent Specimen" (12 Jun. 2011) 4 Feb. 2013. < http://www.designboom.com/art/iori-tomita-newworld-transparent-specimens/>. 
By Author. Meech Lake Crossing. 2012.

\section{Program}

Schulz, Charles M. "I'm Happy." Cartoon. 13 Nov. 2012. <http://jennibgoode. blogspot.ca/2011/02/im-happy-too.html>.

By Author. Nature + Science = ?. 2013 .

By Author. Toolik Field Station Equipment. 2013.

By Author. Kit-of-Parts Assemblies. 2013.

By Author. Site Servicecs. 2013.

\section{Process}

By Author. Bay of Islands Color Blocked. 2012.

By Author. Gatineau Park Topography. 2013.

By Author. Forgotten Espadrilles. 2012.

\section{Materiality}

By Author. Rock vs. Plant. 2009.

By Author. Gatineau Park Landscape vs. Fabric. 2013.

By Author. Morphing Trees. 2013.

By Author. Rooflines. 2013.

By Author. Rock Layers. 2013.

By Author. Cladding Types. 2013.

\section{Design}

By Author. Site Panorama 2. 2012.

By Author. Mind Map 1. 2012.

By Author. Mind Map 2. 2012. 
Macdonald, Christopher. Cabin, Cottage \& Camp: New Designs on the Canadian Landscape. Bluemprint: Italy, 2005. 52.

By Author. Trees Pavilion Interior Vignette 1. 2013.

By Author. Water Pavilion Interior Vignette 1. 2013.

By Author. Earth Pavilion Interior Vignette 1. 2013.

\section{Pavilion Documentation}

By Author. Pavilion Theme Triptych. 2013.

By Author. Site Maps. 2013.

By Author. Trees Pavilion Exterior Vignette 1. 2013.

By Author. Trees Pavilion Plan. 2013.

By Author. Trees Pavilion South Elevation. 2013.

By Author. Trees Pavilion West Elevation. 2013.

By Author. Trees Pavilion North Elevation. 2013.

By Author. Trees Pavilion East Elevation. 2013.

By Author. Trees Pavilion Section 1. 2013.

By Author. Trees Pavilion Section 2. 2013.

By Author. Trees Pavilion Interior Vignette 2. 2013.

By Author. Trees Pavilion Exterior Vignette 2. 2013.

By Author. Water Pavilion Exterior Vignette 1. 2013.

By Author. Water Pavilion Plan. 2013.

By Author. Water Pavilion South Elevation. 2013.

By Author. Water Pavilion West Elevation. 2013.

By Author. Water Pavilion North Elevation. 2013.

By Author. Water Pavilion East Elevation. 2013.

By Author. Water Pavilion Section 1. 2013.

By Author. Water Pavilion Section 2. 2013.

By Author. Water Pavilion Interior Vignette 2. 2013. 
By Author. Water Pavilion Exterior Vignette 2. 2013.

By Author. Earth Pavilion Exterior Vignette 1. 2013.

By Author. Earth Pavilion Plan. 2013.

By Author. Earth Pavilion South Elevation. 2013.

By Author. Earth Pavilion West Elevation. 2013.

By Author. Earth Pavilion North Elevation. 2013.

By Author. Earth Pavilion East Elevation. 2013.

By Author. Earth Pavilion Section 1. 2013.

By Author. Earth Pavilion Section 2. 2013.

By Author. Earth Pavilion Interior Vignette 2. 2013.

By Author. Earth Pavilion Exterior Vignette 2. 2013. 